\title{
Caddo Ceramic Vessels from the Hatchel Site (41BW3) on the Red River in Bowie County, Texas
}

Timothy K. Perttula

Heritage Research Center, Stephen F. Austin State University

Follow this and additional works at: https://scholarworks.sfasu.edu/ita

Part of the American Material Culture Commons, Archaeological Anthropology Commons, Environmental Studies Commons, Other American Studies Commons, Other Arts and Humanities Commons, Other History of Art, Architecture, and Archaeology Commons, and the United States History Commons

Tell us how this article helped you.

This Article is brought to you for free and open access by the Center for Regional Heritage Research at SFA ScholarWorks. It has been accepted for inclusion in Index of Texas Archaeology: Open Access Gray Literature from the Lone Star State by an authorized editor of SFA ScholarWorks. For more information, please contact cdsscholarworks@sfasu.edu. 


\section{Caddo Ceramic Vessels from the Hatchel Site (41BW3) on the Red River in Bowie County, Texas}

\section{Creative Commons License}

\section{(c) (1) \&}

This work is licensed under a Creative Commons Attribution-NonCommercial 4.0 International License 


\title{
Caddo Ceramic Vessels from the Hatchel Site (41BW3) on the Red River in Bowie County, Texas
}

\author{
Timothy K. Perttula
}

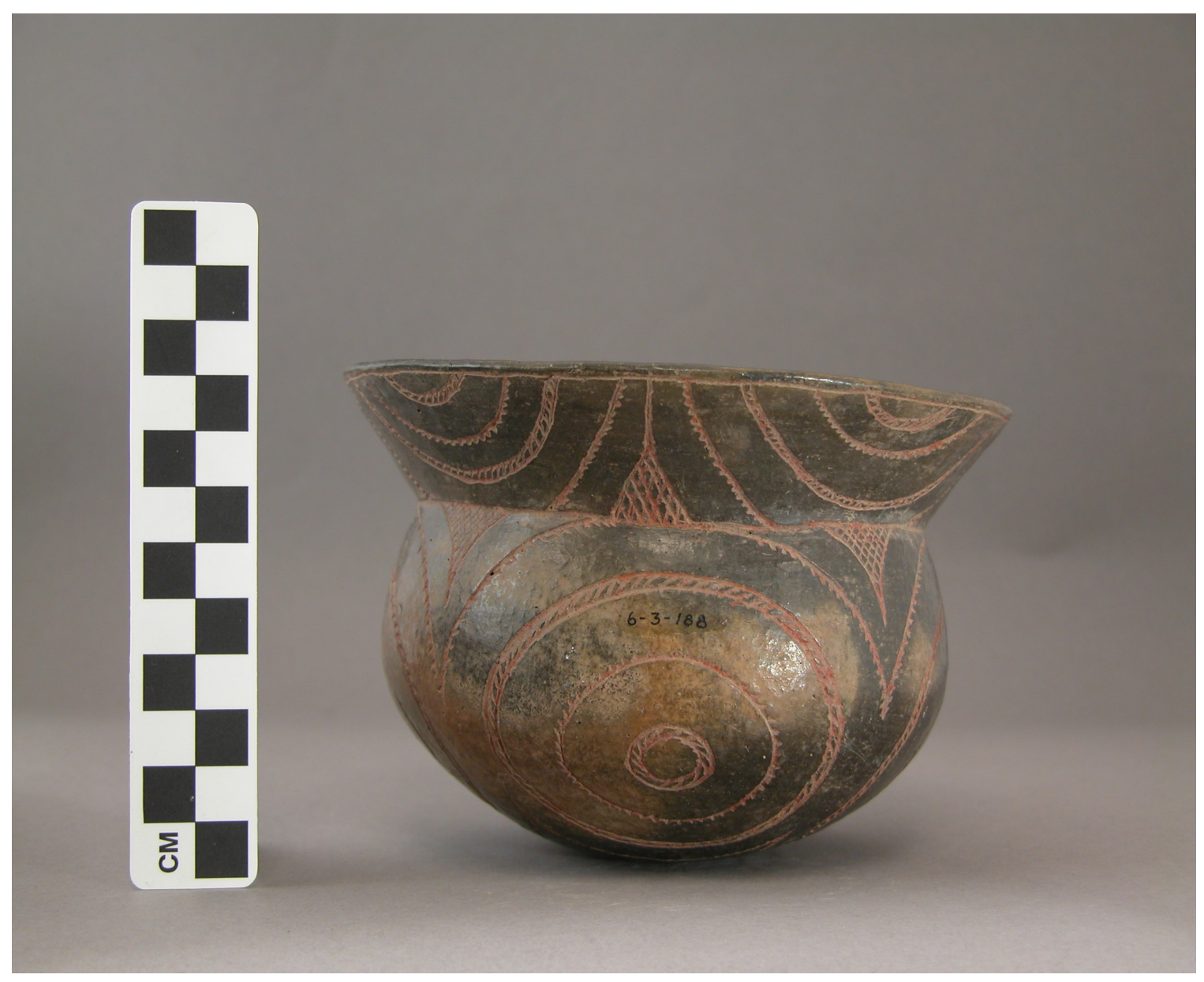

Special Publication No. 39

Friends of Northeast Texas Archaeology, Austin and Pittsburg 
Friends of Northeast Texas Archaeology Editor, Timothy K. Perttula 10101 Woodhaven Dr.

Austin, Texas 78753

tkp4747@aol.com

Friends of Northeast Texas Archaeology, Distribution, Bo Nelson, 344 CR 4154

Pittsburg, Texas 75686

RBoNelson@aol.com

Cover art: Avery Engraved jar, F.S. 378, Mound, Feature 12, Floor D

Copyright (C) 2015, Friends of Northeast Texas Archaeology

(Pittsburg and Austin) 


\section{Table of Contents}

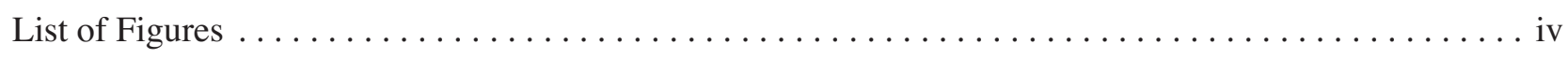

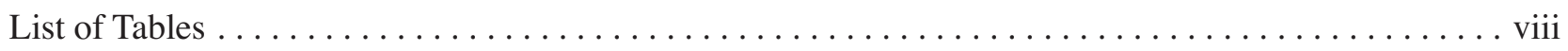

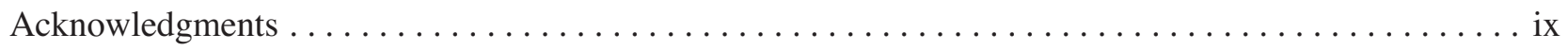

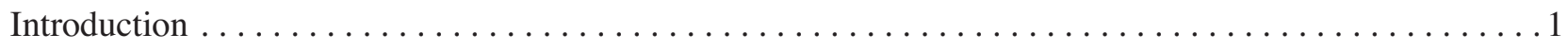

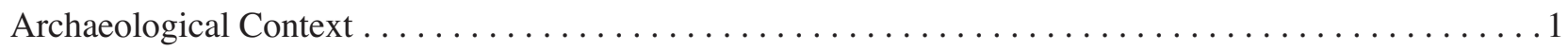

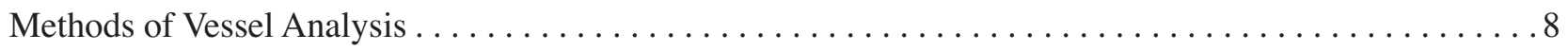

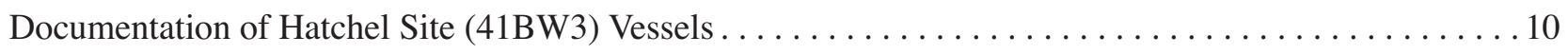

Platform Mound Features . . . . . . . . . . . . . . . . . . . . . . 10

Vessels from Burial Plot Features. . . . . . . . . . . . . . . . . . . . . 40

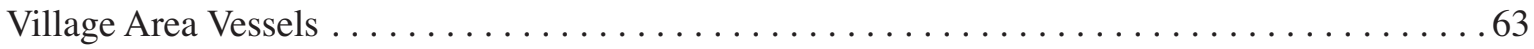

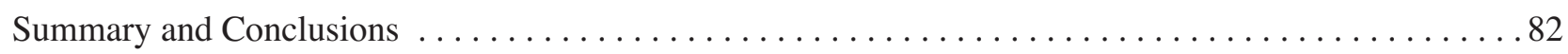

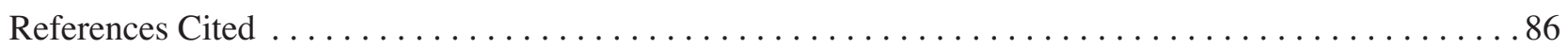




\section{List of Figures}

1. The mounds and village area at the Hatchel site: a, overview; b, platform mound, WPA village and burial plots, and Village areas; c, the location of the Hatchel site in the broader Caddo archaeological area. . . . . . . . . . . . . . . . . . . . . . $2-4$

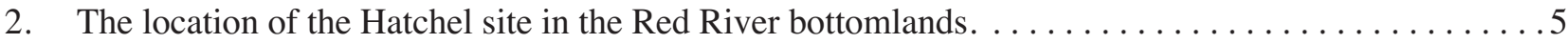

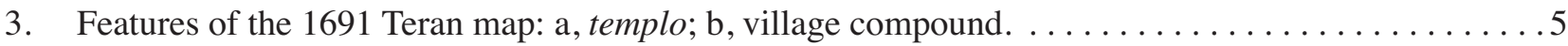

4. The Hatchel site and other Nasoni Caddo sites on the Red River in Bowie County, Texas... . . . . . .5

5. The platform mound at the Hatchel site: a, WPA map showing the Hatchel mound, Burial Plots 1-4, and 1938-1939 farm structures; b, looking south at the Hatchel platform mound from the edge of the Red River floodplain. Image 41BW3-9, Texas Archeological Research

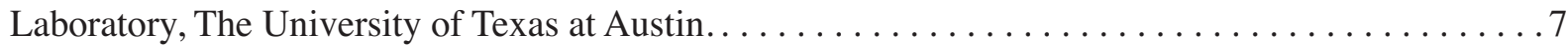

6. Cross-section of Zones A-K in the platform mound excavations at the Hatchel site. . . . . . . . . . 10

7. Lower body and base section of plain jar, F.S. 379 in Zone D in the platform mound at

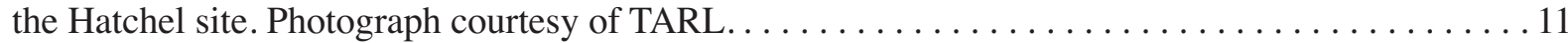

8. Black Avery Engraved jar (6-3-188) from Feature 12 in Zone D of the platform mound: a, photograph; b, redrawn from Laughlin (1940). Photograph courtesy of TARL . . . . . . . . 12

9. Foster Trailed-Incised jar (6-3-189) in Burial 1 in Zone E in the platform mound at

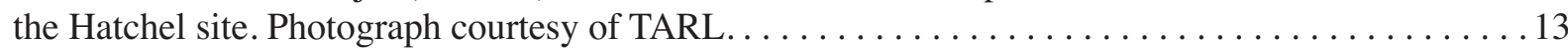

10. Drawings of vessels from Zone E, including Burial 1: a, Keno Trailed jar; b, Simms Engraved carinated bowl; c, Foster Trailed-Incised, var. unspecified jar. Redrawn

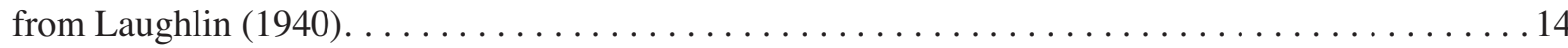

11. Keno Trailed jar (6-3-190) in Burial 1 in Zone $\mathrm{E}$ in the platform mound at the Hatchel site.

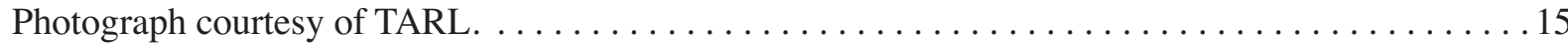

12. Simms Engraved carinated bowl (6-3-191) from Feature 14 in Zone E of the platform

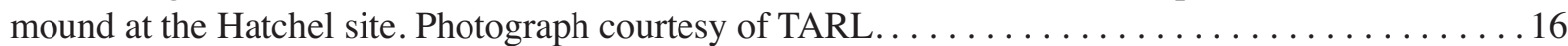

13. Plain carinated bowl (6-3-193) from Zone F in the platform mound at the Hatchel site: a, photograph; b, drawing, redrawn from Laughlin (1940). Photograph courtesy of TARL. . . . . . 17

14. Barkman Engraved carinated bowl (6-3-194) in Burial 2, Zone F, in the platform mound at the Hatchel site: a, photograph, courtesy of TARL; b, drawing, redrawn from Laughlin (1940). . . . . . . . . . . . . . . . . . . . . . . . . . . . . . . 18

15. Foster Trailed-Incised, var. unspecified jar (6-3-195) in Burial 2 in Zone $F$ of the platform mound at the Hatchel site: a, photograph, courtesy of TARL; b, drawing, redrawn from Laughlin $(1940) \ldots \ldots \ldots \ldots \ldots \ldots \ldots$. . . . . . . . . . . . . . . . . . . . . . . . 19

16. Foster Trailed-Incised, var. Red Lake jar (6-3-196) in Burial 2 in Zone F in the platform mound at the Hatchel site: a, photograph, courtesy of TARL; b, drawing, redrawn

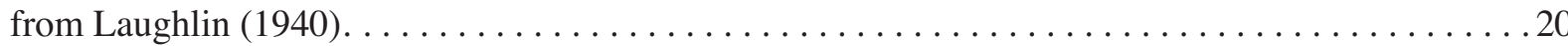

17. Simms Engraved carinated bowl (6-3-197) in Zone F of the platform mound at the Hatchel site: a, photograph, courtesy TARL; b, drawing, redrawn from Laughlin (1940).. . . . . 21 
18. Karnack Brushed-Incised jar (6-3-198) in Zone F of the platform mound at the Hatchel site: a, photograph, courtesy TARL; b, drawing, redrawn from Laughlin $(1940) \ldots . . \ldots \ldots$. . . . . . . 22

19. Lip-notched bowl (F.S. 754) in Zone G in the platform mound at the Hatchel site.

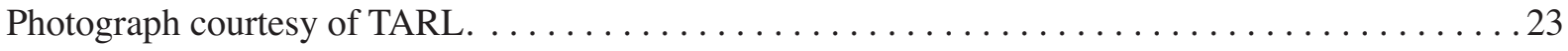

20. Incised jar (6-3-199) in Feature 22 in Zone $G$ in the platform mound at the Hatchel site.

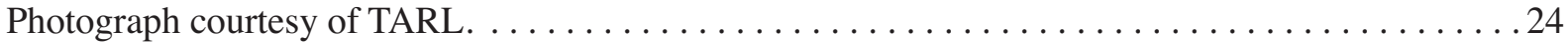

21. Avery Engraved, var. Bradshaw compound bowl (6-3-200) from Burial 3 in Zone $\mathrm{H}$ of the platform mound at the Hatchel site. Photograph courtesy of TARL. . . . . . . . . . 25

22. Vessels from Burial 3 in Zone H: a, Avery Engraved, var. Bradshaw compound bowl; b, McKinney Plain jar; c, appliqued bowl with broken pedestal legs. Redrawn

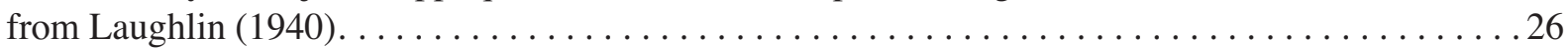

23. McKinney Plain jar (6-3-201) in Burial 3 in Zone $\mathrm{H}$ in the platform mound at

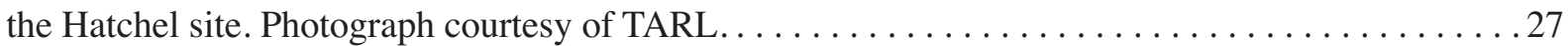

24. Appliqued bowl with pedestal legs (6-3-202) in Burial 3 in Zone $\mathrm{H}$ in the platform

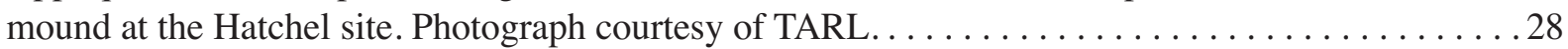

25. Decorative element on engraved olla (F.S. 993/994) in Zone H in the platform mound

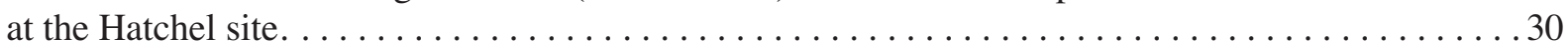

26. Belcher Engraved, var. Belcher carinated bowl section (F.S. 1297) in Features 19 and 20 in Zone $\mathrm{H}$ in the platform mound at the Hatchel site . . . . . . . . . . . . . . . . 31

27. Decorative elements on Barkman Engraved carinated bowl (F.S. 1432) under Zone H in the platform mound at the Hatchel site . . . . . . . . . . . . . . . . . . . . . . 32

28. Barkman Engraved carinated bowl section (F.S. 1596), above Zone I in the platform mound at the Hatchel site. . . . . . . . . . . . . . . . . . . . . . . . . . . . . . . 33

29. Crockett Curvilinear Incised (6-3-206) carinated bowl in Zone K in the platform mound at the Hatchel site: a, photograph, courtesy of TARL; b, drawing, redrawn

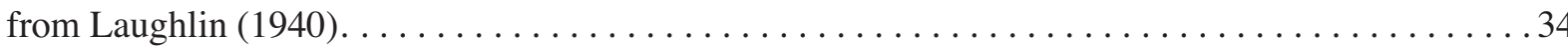

30. Plain jar (6-3-203) in Burial 4 in the platform mound at the Hatchel site.

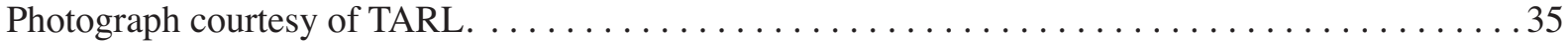

31. Drawings of vessels from Burial 4 in the platform mound at the Hatchel site: a, Hodges Engraved, var. Candler bottle; b, engraved bowl; c, plain jar. . . . . . . . . . . . 36

32. Hodges Engraved, var. Candler bottle in Burial 4 in the platform mound at the Hatchel site.

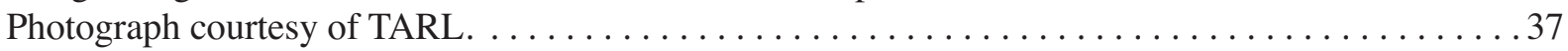

33. Engraved bowl (6-3-205) in Burial 4 in the platform mound at the Hatchel site.

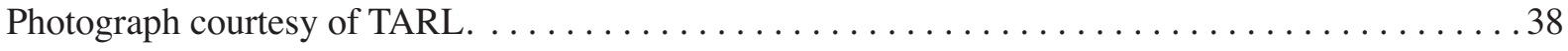

34. cf. Belcher Engraved, var. Ogden jar (F.S. 1648) in the platform mound at

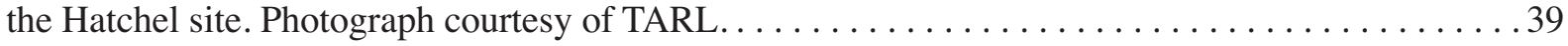

35. McKinney Plain jar (6-1-1) in Burial 1 in Burial Plot 1 at the Hatchel site.

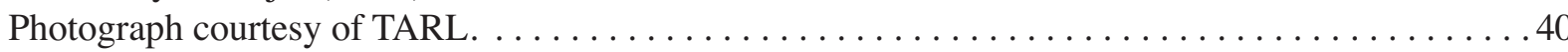

36. Hatchel Engraved bottle (6-1-2) in Burial 1 in Burial Plot 1 at the Hatchel site. Photograph courtesy of TARL. 
37. Keno Trailed, var. Glendora bottle (6-1-3) in Burial 2 in Burial Plot 2 at the Hatchel site. . . . . .42

38. Side and top views of an engraved bowl (6-1-4) from Burial 10 in Burial Plot 1 at the

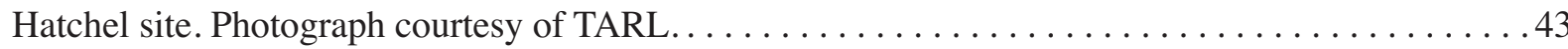

39. Punctated-appliqued jar (6-1-5) from Burial Plot 1 at the Hatchel site. Photograph courtesy

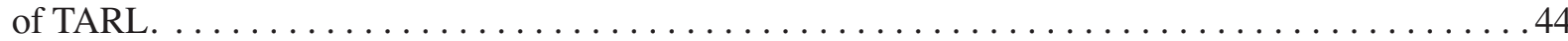

40. Plain jar (6-1-6) from Burial Plot 1 at the Hatchel site. Photograph courtesy of TARL. . . . . . . . . 45

41. Engraved bottle (6-1-7) in Burial Plot 1, Burial 14 at the Hatchel site. Photograph courtesy

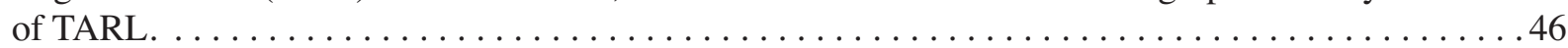

42. Crockett Curvilinear Incised four-sided bowl (6-1-8) in Burial 14 in Burial Plot 1 at the

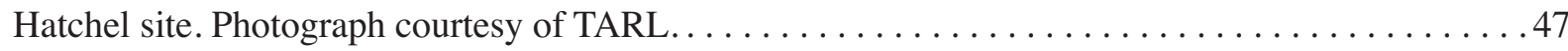

43. Simms Engraved carinated bowl (6-1-13) in Burial Plot 1 at the Hatchel site. Photograph courtesy of TARL. ....................................... 48

44. Barkman Engraved carinated bowl (6-1-20) in Burial 20 in Burial Plot 2 at the Hatchel site.

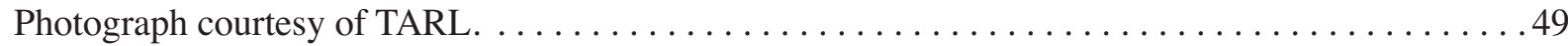

45. Brushed-incised and punctated jar (6-1-22) in Burial 20 in Burial Plot 2 at the Hatchel site.

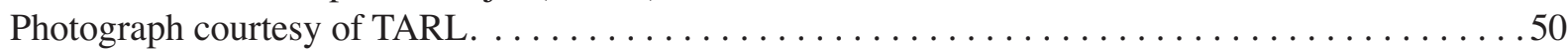

46. Nash Neck Banded jar (6-1-23) in Burial 21 in Burial Plot 2 at the Hatchel site. Photograph

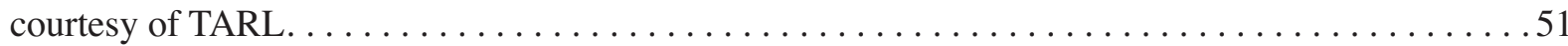

47. Nash Neck Banded jar (6-1-24) in Burial 21 in Burial Plot 2 at the Hatchel site. Photograph

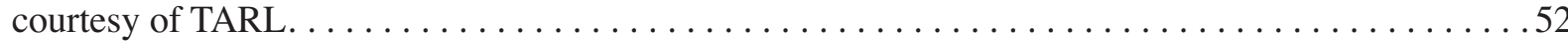

48. Incised-punctated jar (6-1-25) in Burial 21 in Burial Plot 2 at the Hatchel site. Photograph

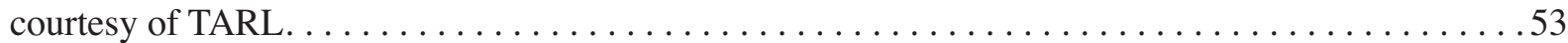

49. Plain jar vessel section (6-1-27): a, photograph, courtesy of TARL; b, engraved decorative elements on vessel base. . . . . . . . . . . . . . . . . . . . . . . . . . . . . 54

50. Plain jar (6-1-28) in Burial Plot 2, Burial 23 at the Hatchel site. Photograph courtesy of TARL. . . 55

51. Barkman Engraved carinated bowl (6-1-29) in Burial 23 in Burial Plot 2 at the Hatchel site.

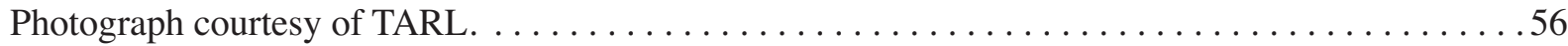

52. Hodges Engraved, var. Armour carinated bowl (6-1-30) in Burial 23 in Burial Plot 2

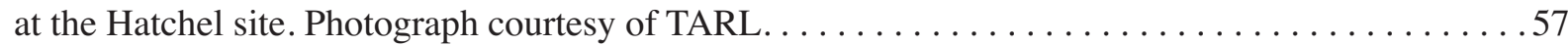

53. Simms Engraved carinated bowl (6-1-31) in Burial 34 in Burial Plot 4 at the Hatchel

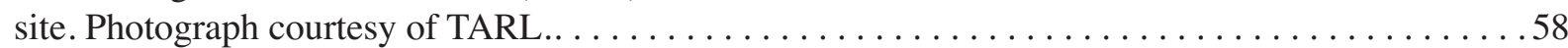

54. Barkman Engraved carinated bowl (6-1-33a) in Burial Plot 2 at the Hatchel site.

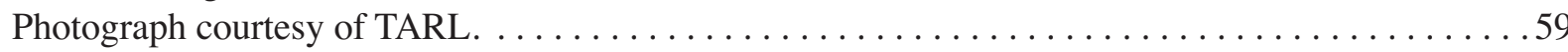

55. Decorative motif on Barkman Engraved carinated bowl (6-1-33d) from Burial Plot 3

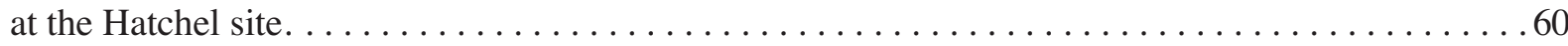

56. Incised-appliqued jar (6-1-33e) from Burial Plot 3 at the Hatchel site. Photograph

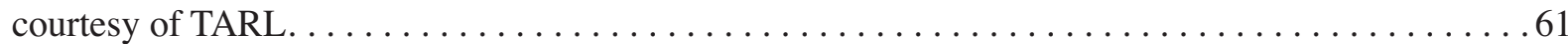

57. Punctated-appliqued jar section (6-1-33f) in Burial Plot 3 at the Hatchel site. Photograph courtesy of TARL. 
58. Plain jar section (6-1-33b) in Village area north-northwest of the platform mound at the

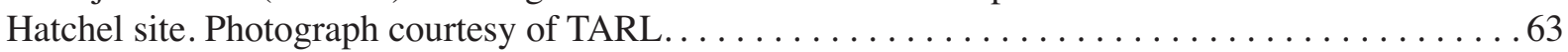

59. Hatchel Engraved bottle (6-4-580) in Burial 2 in Village Plot 1 at the Hatchel site. . . . . . . . . 64

60. Moore Noded bowl (6-4-581) in Burial 2 in Village Plot 1 at the Hatchel site . . . . . . . . . . . 65

61. McKinney Plain jar (6-4-582) in Burial 2 in Village Plot 1 at the Hatchel site . . . . . . . . . .66

62. Incised jar (6-4-592) in Feature 4 in Village Plot 2 at the Hatchel site... . . . . . . . . . . 67

63. Hatchel Engraved bottle (6-6-604) in Burial 1 in Village Plot 2 at the Hatchel site. . . . . . . . . .68

64. cf. Avery Engraved compound bowl (6-6-605) in Burial 1 in Village Plot 2 at the Hatchel site. . . . 69

65. Appliqued-punctated compound bowl (6-6-606) in Burial 1 in Village Plot 2 at the Hatchel site... . . 70

66. Simms Engraved carinated bowl (6-6-607) in Burial 2 in Village Plot 2 at the Hatchel site........ 71

67. Avery Engraved, var. Graves carinated bowl in Burial 2 in Village Plot 2 at the Hatchel site... .... 72

68. Belcher Engraved, var. Ogden bottle (6-6-609) in Burial 2 in Village Plot 2 at the Hatchel site..... 73

69. McKinney Plain jar (6-6-610) in Burial 2 in Village Plot 2 at the Hatchel site . . . . . . . . . . . 74

70. Incised bowl (6-6-611) in Burial 2 in Village Plot 2 at the Hatchel site. . . . . . . . . . . . 75

71. Trailed-punctated bottle (6-6-621) in Burial 3 in Village Plot 2 at the Hatchel site........... . 76

72. Punctated-appliqued jar (6-6-622) in Burial 3 in Village Plot 2 at the Hatchel site........... . 77

73. Appliqued-punctated jar (6-6-623) in Burial 3 in Village Plot 2 at the Hatchel site. . . . . . . . . . 78

74. Barkman Engraved carinated bowl (6-6-625) in Burial 7 in Village Plot 2 at the Hatchel site. . . . . 79

75. Plain effigy bowl (6-6-626) with a tab tail attachment from Burial 9 in Village Plot 2

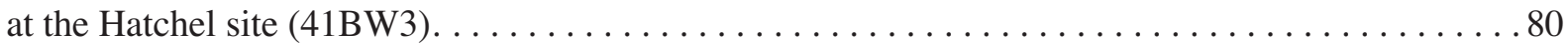

76. Engraved carinated bowl (6-6-630) in Burial 10 in Village Plot 2 at the Hatchel site..........81 


\section{List of Tables}

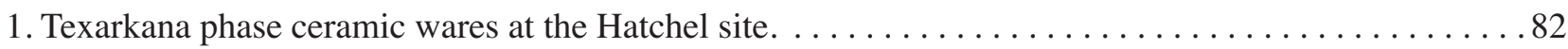

2. Texarkana phase ceramic vessel forms at the Hatchel site $\ldots \ldots \ldots \ldots \ldots \ldots \ldots \ldots \ldots \ldots \ldots$

3. Ceramic types identified in Texarkana phase contexts at the Hatchel site . . . . . . . . . . . . 83

4. Temper identified in Texarkana phase ceramics at the Hatchel site . . . . . . . . . . . . . . . . 84

5. Use of clay pigments in Texarkana phase vessels from the Hatchel site $\ldots \ldots \ldots \ldots \ldots \ldots \ldots \ldots 4$ 


\section{Acknowledgments}

I appreciate the access provided by the Caddo Nation of Oklahoma as well as the staff at the Texas Archeological Research Laboratory at The University of Texas at Austin (TARL), in particular Marybeth Tomka, to the records and vessel collections from the Hatchel site. Thanks also to TARL (and Laura Nightengale) for providing the photographic images used in this volume. Lance Trask and Sandra Hannum prepared various figures for the volume. 



\section{Introduction}

This monograph concerns the analysis and study of the ancestral Caddo ceramic vessels $(n=68)$ recovered at the Hatchel site (41BW3) on the Red River in Bowie County, Texas. These vessels were excavated from burial and non-burial features in the platform mound, village areas, and cemetery areas (burial plots 1-4) excavated by University of Texas archaeologists during 1938-1939 Works Progress Administration (WPA) investigations (see Jackson 2003; Perttula 2005, 2014a). The vessels are curated at the Texas Archeological Research Laboratory at The University of Texas (TARL).

\section{Archaeological Context}

The principal occupation of this part of the Red River basin in East Texas in prehistoric and early historic times (up to about A.D. 1790) was by Caddo-speaking Indian groups that lived in settled horticultural and agricultural communities. These communities were composed principally of farmsteads and small hamlets, but larger villages, as at the Hatchel, Mitchell (41BW4), Eli Moores (41BW2) and Cabe (41BW14) sites (see Figure 1), were situated along the Red River bottomlands during much of the prehistoric and historic era (e.g., Story 1990; Creel 1996; Perttula 2005, 2014a, 2014b, 2014c; Perttula et al. 1995), particularly during the Late Caddo period Texarkana phase after ca. A.D. 1400, the latest prehistoric Caddo culture in the area (Creel 1996:505). Caddo archaeological sites in the region are known to be primarily located on elevated landforms (alluvial terraces and rises, natural levees, and upland edges) adjacent to the major streams, as well as along spring-fed branches and smaller tributaries with dependable water flow. They are also located in proximity to arable sandy loam soils, presumably for cultivation purposes with digging sticks and stone celts.

These Caddo groups were powerful theocratic chiefdoms that built earthen mounds (like the platform mound at the Hatchel site, see Jackson 2003, Perttula 2014a) for political and religious purposes, functions, and rituals, traded extensively across the region as well as with non-Caddoan speaking groups, and developed intensive maize-producing economies by the 13th century A.D. (Perttula et al. 2014). Due to diseases introduced by Europeans sometime after the mid-16th century, and the incursions of the Osage to obtain deer hides and Caddo slaves, by about 1790, the Red River valley in the Texarkana area was abandoned by the Caddo groups.

The Hatchel site (41BW3) is a major prehistoric and protohistoric Caddo village and mound center on a natural levee deposit in the floodplain of the Red River in Bowie County, Texas. The platform mound and the main part of the associated village overlooks two channel lakes of the river; these likely were part of the channel of the river when the site was occupied by the Caddo (Figures 1a-c and 2).

The site was occupied by the Caddo from at least A.D. 1040 to the late 17th century. The earliest end of this age range is based on 2-sigma calibrated ages from radiocarbon dates obtained in the site's village areas (Perttula and Nelson 2003; Perttula 2005).

In 1691, a Spanish expedition led by Don Domingo Teran de los Rios explored the Red River area (Hatcher 1999), and a detailed map was drawn of a Nasoni Caddo village that depicted a templo or temple mound at the western end of the village (Figure 3a). That mound has been identified as the large earthen mound at the Hatchel site (see Wedel 1978). The map also showed many houses, and associated outbuildings, from numerous individual compounds in the village (Figure $3 b$ ). The village itself is believed to have extended several miles along the Red River, likely encompassing contemporaneous sites such as Eli Moores (41BW2), Paul Mitchell (41BW4), Hargrove Moores (41BW39), and Horace Cabe (41BW14) (Figure 4). The Roseborough Lake site (41BW5) is a later Nasoni Caddo settlement that postdates the community shown on the Teran map by a generation or more (Gilmore 1986). 


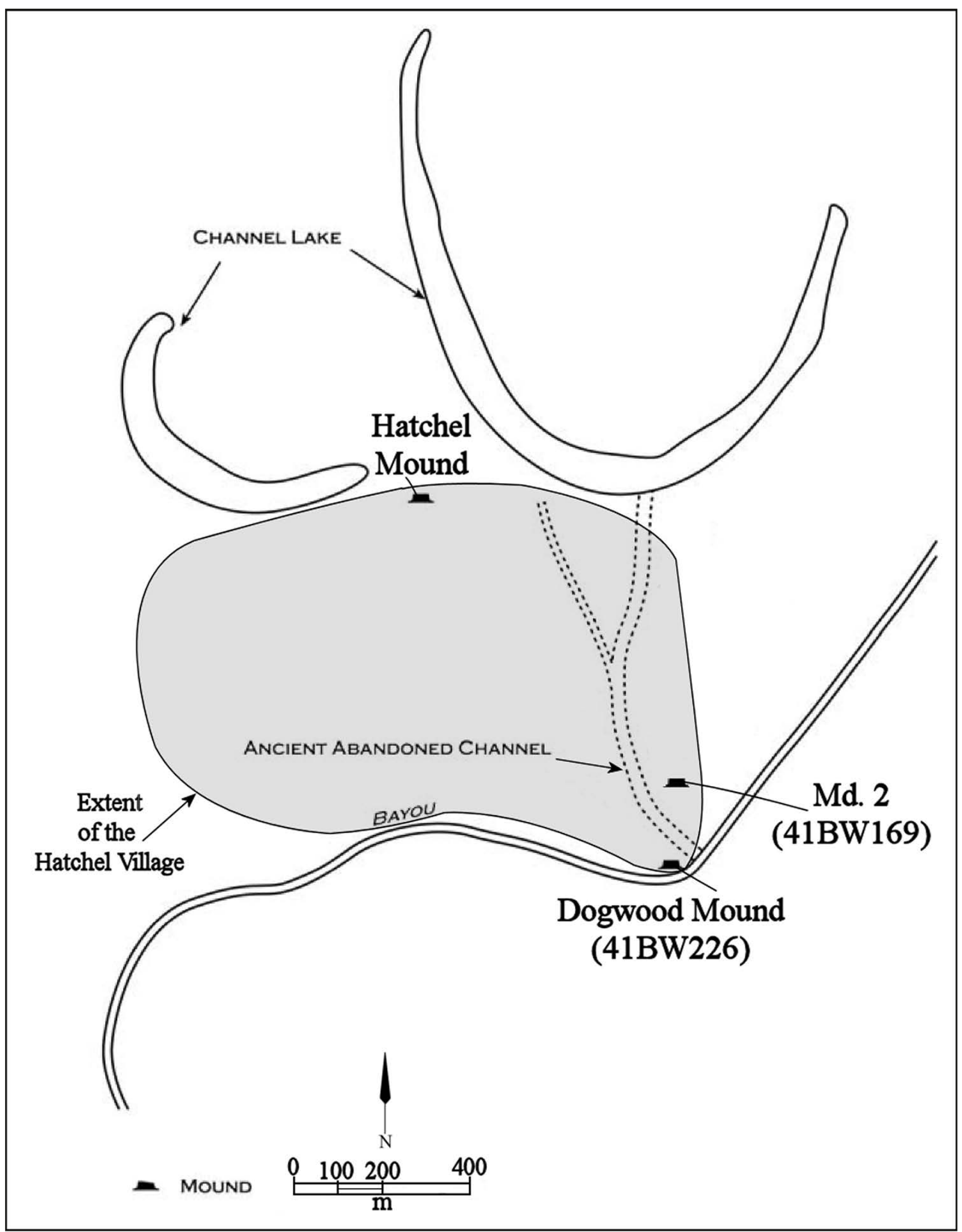

Figure 1. The mounds and village area at the Hatchel site: a, overview; b, platform mound, WPA village and burial plots, and Village areas. 


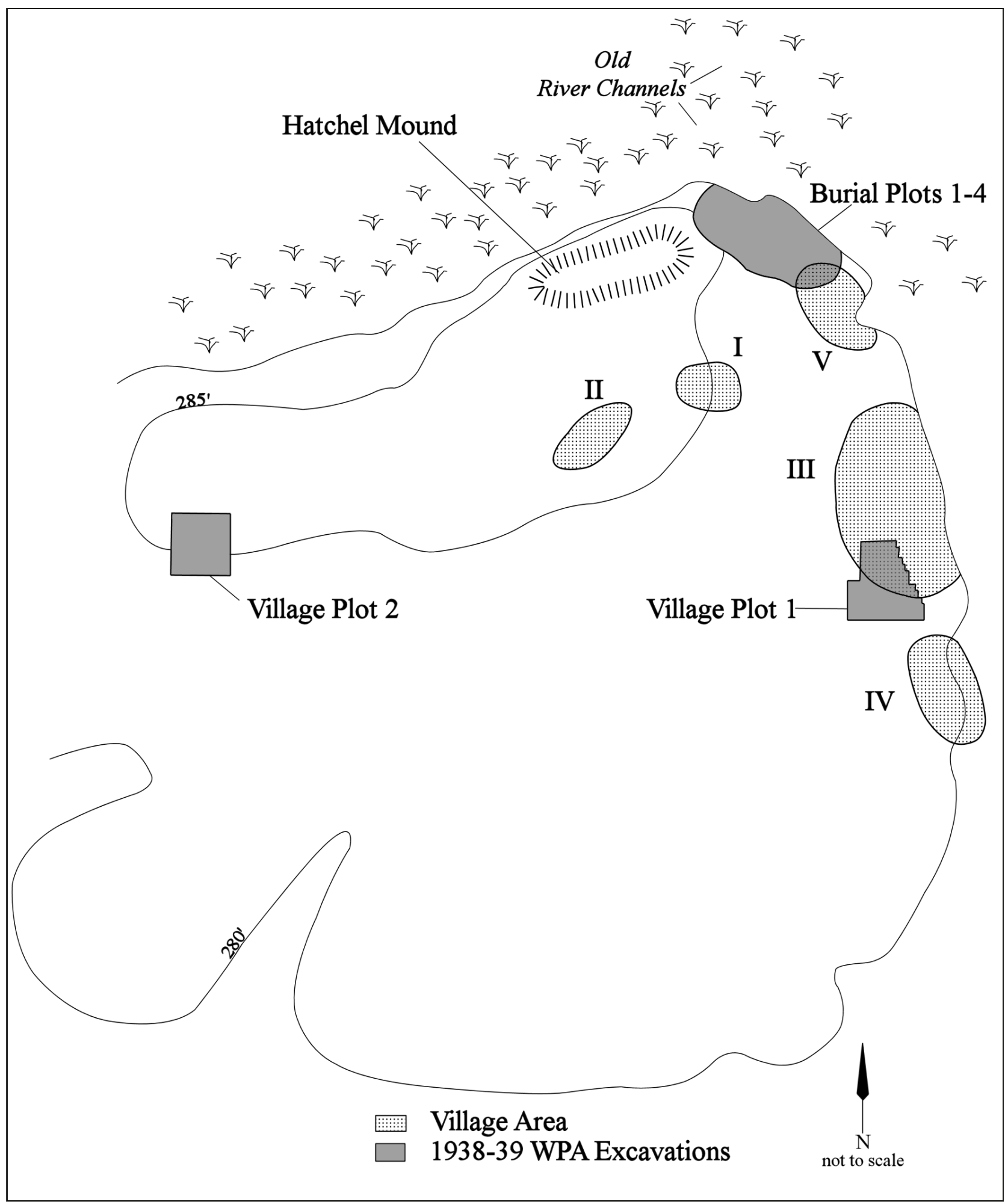

Figure 1. The mounds and village area at the Hatchel site: b, platform mound, WPA village and burial plots, and Village areas 


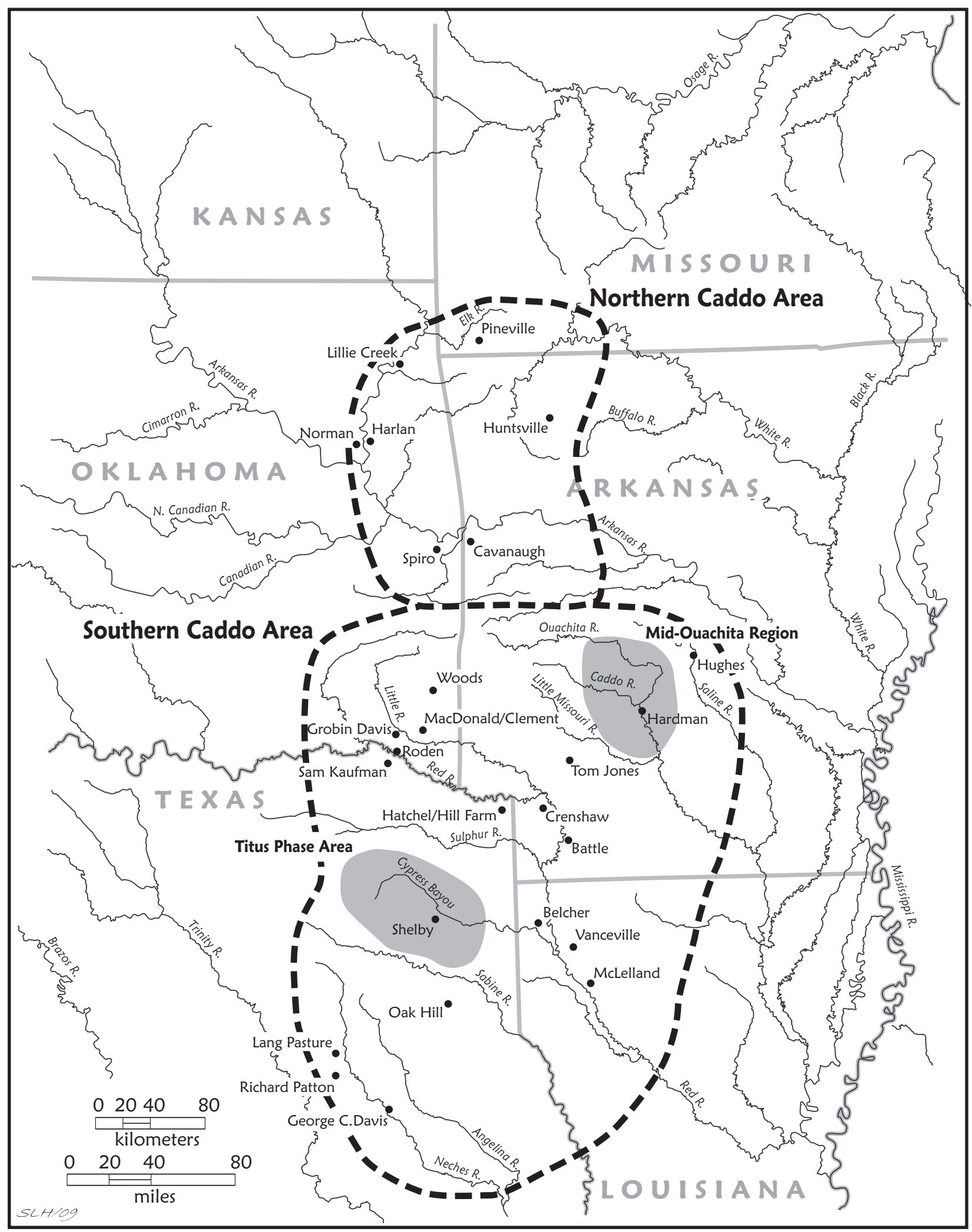

Figure 1. The mounds and village area at the Hatchel site: $c$, the location of the Hatchel site in the broader Caddo archaeological area. 


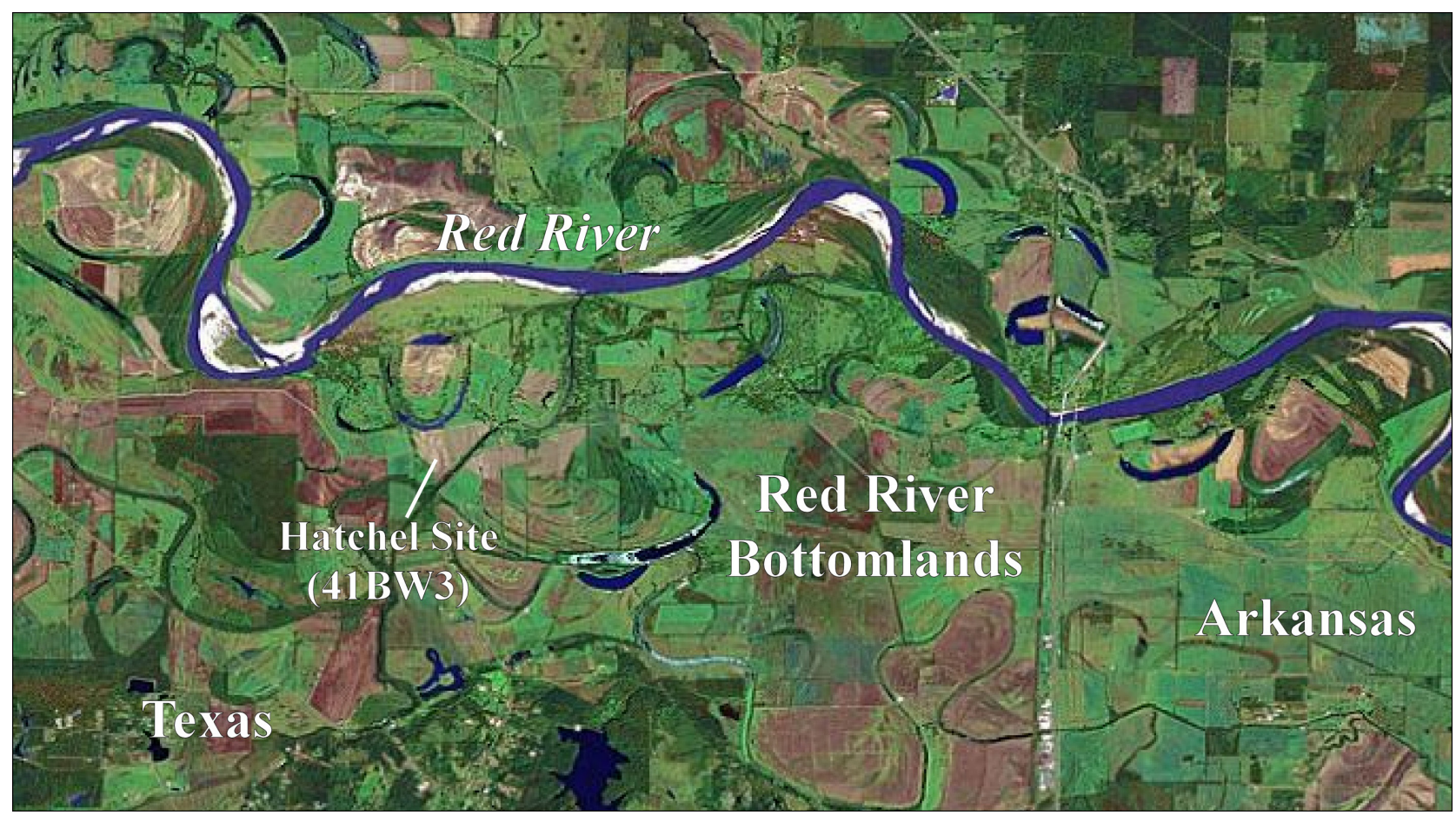

Figure 2. The location of the Hatchel site in the Red River bottomlands.
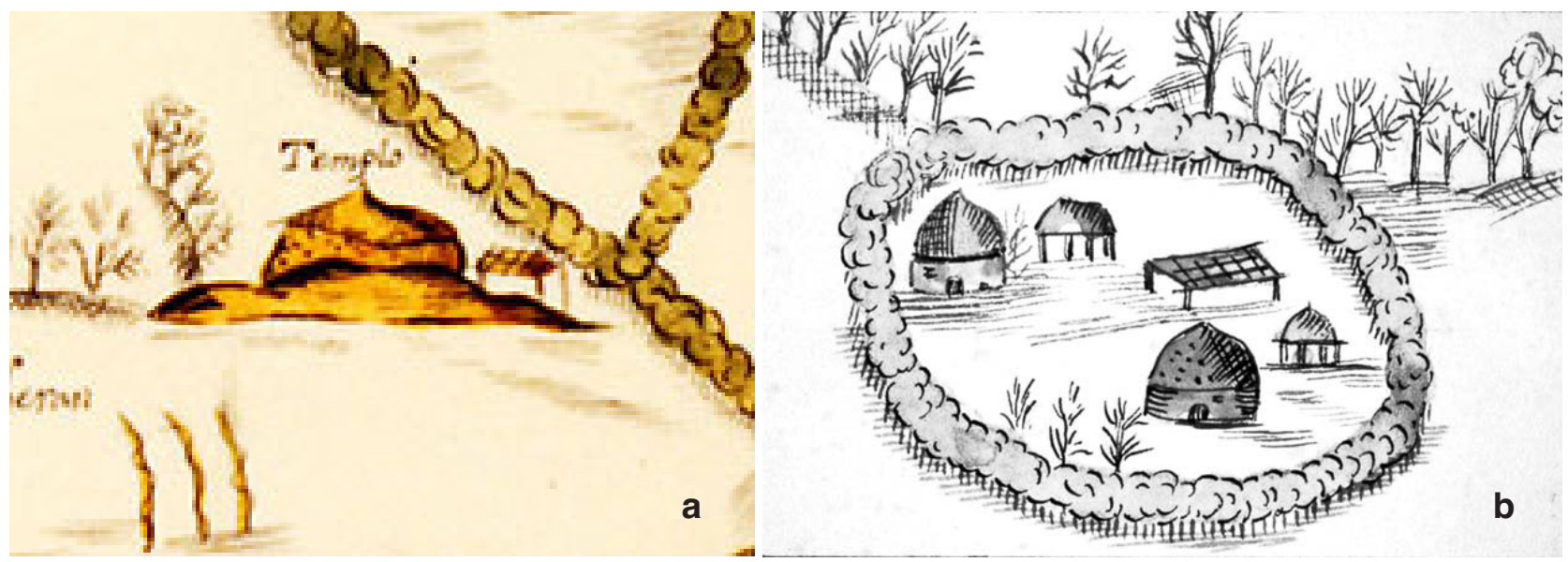

Figure 3. Features of the 1691 Teran map: a, templo; b, village compound.

It is known that the Hatchel site contains extensive village archaeological deposits to the south, southeast, and southwest of the main earthen mound (see Perttula and Nelson 2003; Perttula 2005), as well as village cemetery areas in Burial Plots 1-4 (Figure 5a). The platform mound stood at least $25 \mathrm{ft}$. in height at the time of the Works Progress Administration (WPA) investigations (Figure 5b). A second, and lower mound (Md. 2), stood about $3000 \mathrm{ft}$. southeast of the Hatchel Mound, in a cultivated field some distance east of one of the village areas, in what is considered the Hill Farm site (41BW169, Perttula et al. 2008). 


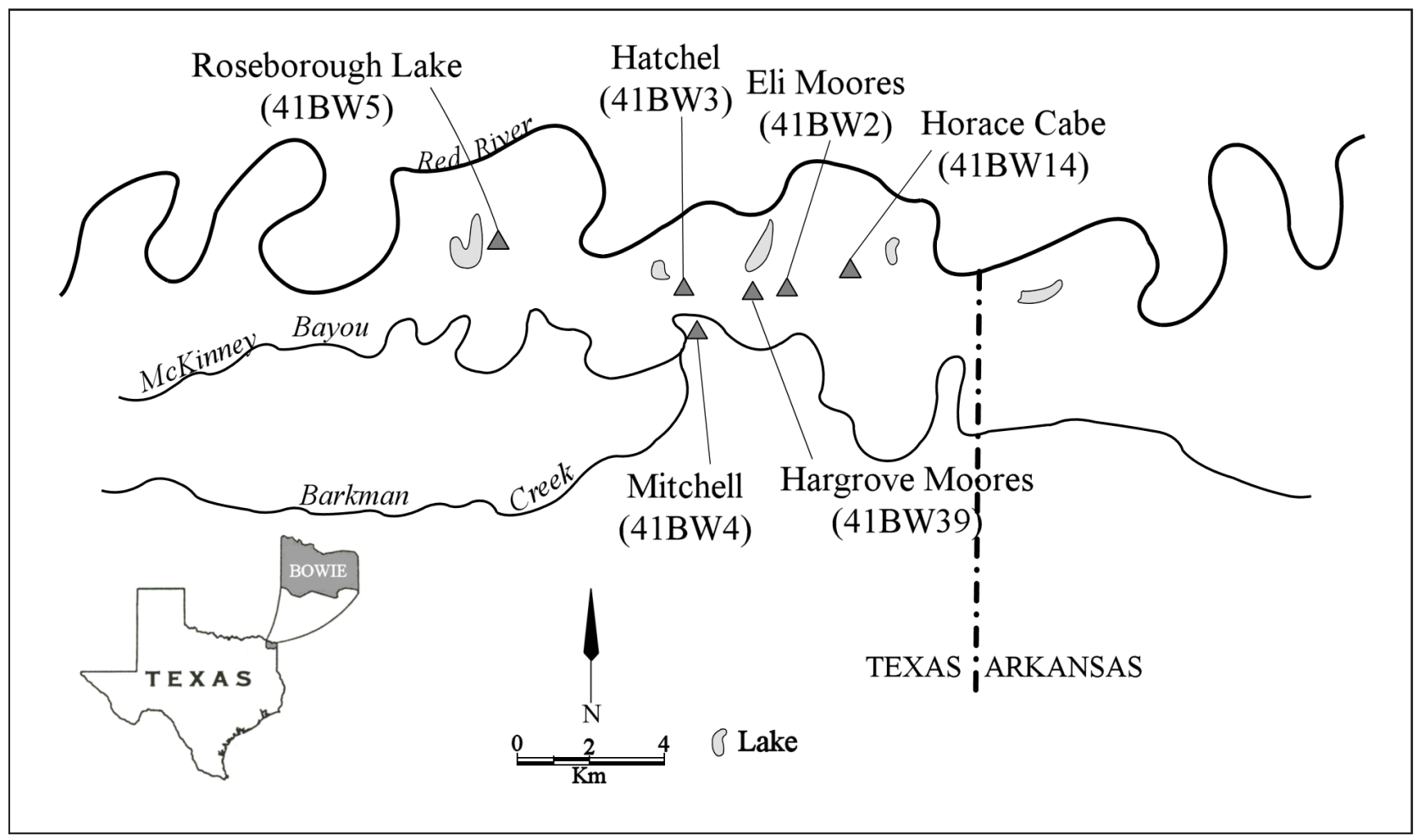

Figure 4. The Hatchel site and other Nasoni Caddo sites on the Red River in Bowie County, Texas.

\section{Methods of Vessel Analysis}

As with other ancestral Caddo ceramic vessel documentation studies recently completed of ceramic assemblages from East Texas sites (cf. Perttula et al. 2011:219-223; Perttula et al. 2013,2015), the following consistent set of attributes were employed in the study and documentation of the ceramic vessels from the Hatchel site:

Non-plastics: Deliberate and indeterminate materials in the paste (Rice 1987:411), including a variety of tempers (i.e., grog or crushed sherds, bone, hematite/ferruginous sandstone, shell, quartz sands, etc.) and "particulate matter of some size." The grog, bone, and hematite/ferruginous sandstone non-plastics appear to have been deliberately added to the paste as tempers. The bone or shell used for temper had been burned and calcined, then crushed, before it was added to the paste.

Vessel Form: Vessel form categories include open containers (bowls of several sizes, including effigy bowls, carinated bowls, and compound bowls) and restricted containers, including jars and bottles, as well as plates. As restricted containers, jars allow access by hand, but bottles do not (Brown 1996:335). Other form attributes that were recorded include the rim profile (outflaring or everted, vertical or standing, and inverted), lip profile (rolled to the exterior, rounded, flat, or thinned), and base shape (flat or rounded).

Core Colors: Observations on ceramic cross-section colors permit consideration of oxidation patterns (Teltser 1993:Figure 2A-H), and thus the conditions under which the vessel was fired and then cooled after firing. Comments are included for these attributes on the presence 


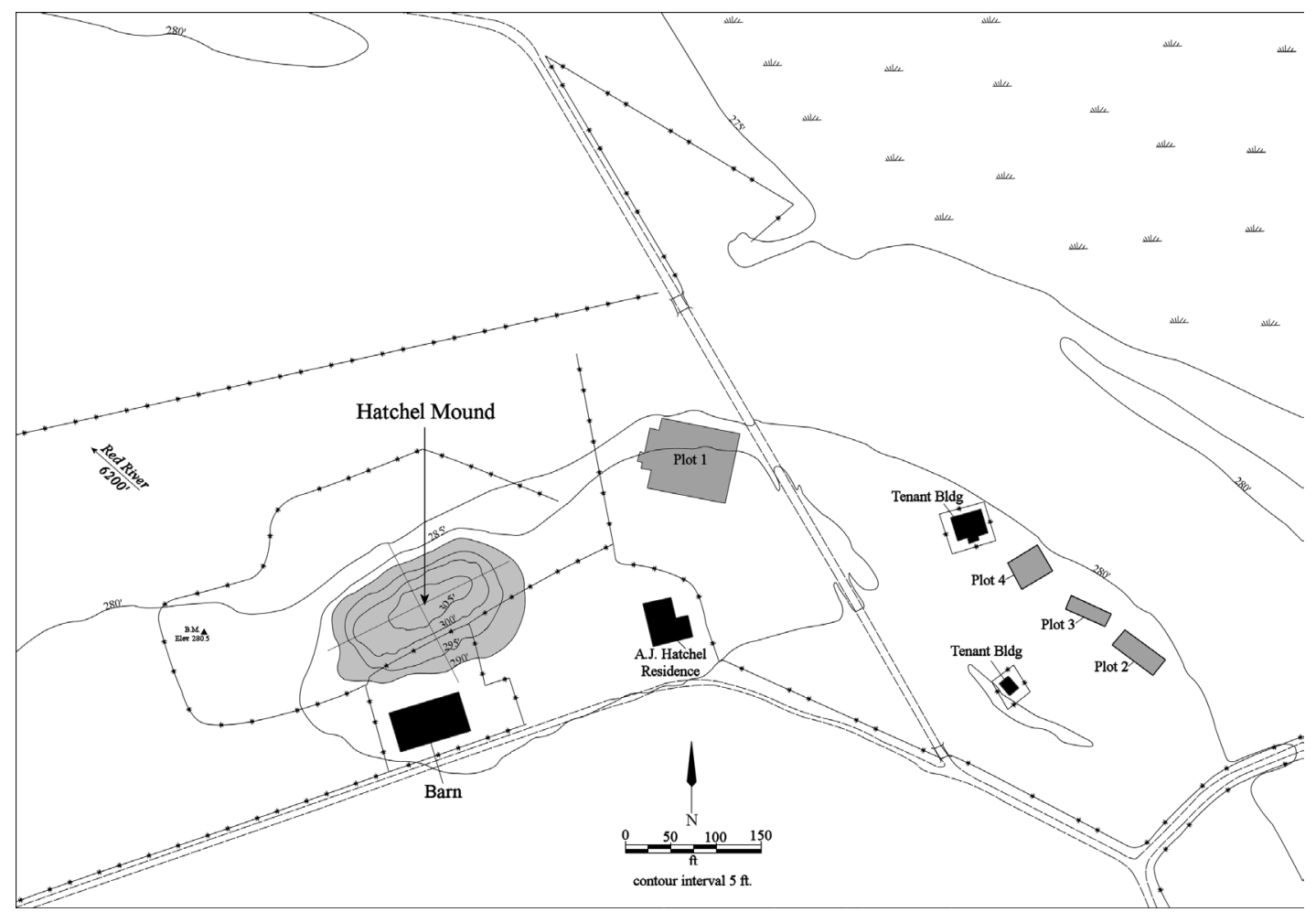

a

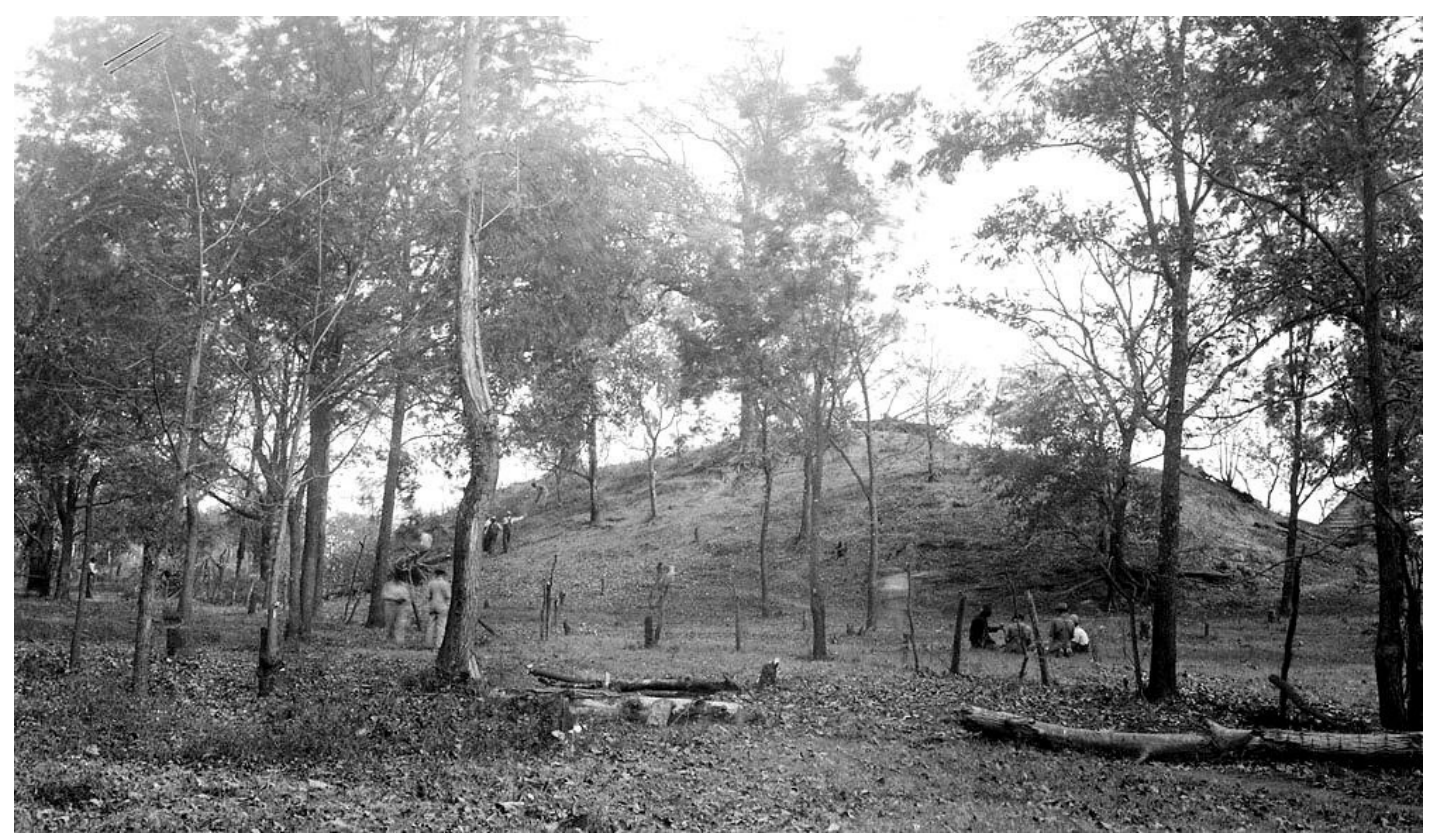

b

Figure 5. The platform mound at the Hatchel site: a, WPA map showing the Hatchel mound, Burial Plots 1-4, and 1938-1939 farm structures; b, looking south at the Hatchel platform mound from the edge of the Red River floodplain. Image 41BW3-9, Texas Archeological Research Laboratory, The University of Texas at Austin. 
and location of fire-clouding, sooting or smudging from cooking use (Skibo 1992), and the preservation of any charred organic remains.

Wall Thickness: Thickness was recorded in millimeters, using a vernier caliper, at the lip, along the rim, at several points along the body, and at the base when possible (only for the vessels that were not complete).

Interior and Exterior Surface Treatment: The primary methods of finishing the surface of the vessels includes either smoothing, burnishing, and polishing (Rice 1987:138). Brushing, while a popular method of roughening the surface (particularly the body) of large and small Middle (ca. A.D. 1200-1450) and Late Caddo (ca. A.D. 1450-1680) period cooking jars in several parts of the Caddo area (Perttula 2015), is here considered a decorative treatment rather than solely a functional surface treatment (cf. Rice 1987:138), although not all Caddo ceramic analysts treat brushing as a decorative treatment. Smoothing creates "a finer and more regular surface... [and] has a matte rather than a lustrous finish" (Rice 1987:138). Burnishing, on the other hand, creates an irregular lustrous finish marked by parallel facets left by the burnishing tool (perhaps a pebble or bone). A polished surface treatment is marked by a uniform and highly lustrous surface finish, done when the vessel is dry, but without "the pronounced parallel facets produced by burnishing leather-hard clay" (Rice 1987:138).

The application of a hematite-rich clay slip (Ferring and Perttula 1987), either red or black after firing in an oxidizing or reducing (i.e., low-oxygen) environment, is another form of surface treatment noted in many East Texas assemblages. On these vessels, the clay slip is more frequently applied on the vessel exterior, or on both surfaces, than on the interior surface, and then was either burnished or polished after it was leather-hard or dry.

Height and Orifice Diameter: These attributes, measured in centimeters, were recorded with a ruler.

Diameter at Bottom of Rim and Base Diameter: Also recorded in millimeters using a ruler, these attributes permit characterization of the overall contour and shape of the vessel.

Volume: With measurements of height and orifice diameter obtained from the vessels, as well as other measurements of size (i.e., base diameter and maximum body width), volumes were estimated by comparison with known vessel volumes of specific forms (i.e., carinated bowl, jar, bottle, compound bowl, and bowl) in other recently documented Caddo vessel assemblages.

Base Shape: this attribute includes the following shapes: circular or square, and flat or round.

Decoration: Decorative techniques present in the Hatchel site vessel collection include engraving, incising, trailing, punctating, pinching, brushing, and appliquéing, and on certain vessels, combinations of decorative techniques (i.e., brushed-punctated) created the decorative elements and motifs. Engraving was done with a sharp tool when the vessel was either leather-hard, or after it was fired, as were the tick marks often seen on vessels in this collection, while the other decorative techniques were executed with tools (trailing, incising, and punctation), by adding strips of clay to the wet body (appliqué), using frayed sticks or grass stems (brushing) dragged across the body surface, or fingernails (certain forms of punctations and pinching), when the vessel was wet or still plastic. Excising is considered a 
form of engraved decoration, where the clay is deliberately and closely marked/scraped and carved away with a sharp tool, usually to create triangular elements, tick marks, or excised punctations.

Use of Pigments: Another form of vessel decoration is the use of red (hematite or ochre) or white (kaolin clay) clay pigments that have been smeared or rubbed into the engraved lines of certain vessels.

Type: The kinds of ceramic types and defined varieties in the collections from East Texas sites follow Suhm and Jelks (1962), Schambach and Miller (1984), and for post-1962 ceramic types: Perttula and Selden (2014). 


\section{Documentation of Hatchel Site (41BW3) Vessels}

A total of 68 Caddo ceramic vessels are documented from the Hatchel site. This includes 26 vessels from features and/or burials in the platform mound, another 23 vessels from individual burials in the Burial Plots northeast and east of the platform mound (see Figure 5a), and 19 other vessels from burials in the WPA village excavations north-northwest, south, and southeast of the platform mound.

\section{Platform Mound Features}

The platform mound at the Hatchel site was constructed in several stages (Figure 6). The first, or principal platform comprises zones I and $\mathrm{J}$-built atop the ground surface (Zone $\mathrm{K}$ ) and a large premound circular structure (Feature 25) - and these platform zones stood $4.2 \mathrm{~m}$ in height, with flat tops (Perttula 2014a). Neither of these mound platform zones apparently had structures constructed atop them. Zone $\mathrm{J}$ was comprised of red and blue clays and was about $22 \mathrm{~m}$ in length, $14 \mathrm{~m}$ in width, thus rectangular, stood $2.2 \mathrm{~m}$ in height, and had steep sides. It contained little in the way of cultural materials. Zone I, on the other hand, was built up from sandy loam deposits - probably scraped up from the surrounding village deposits since no borrow pits have been identified at the site - and it contained an abundance of debris, especially ceramic sherds (Perttula 2014a:Table 1). Zone I was piled atop Zone J and extended the mound until it was more than $40 \mathrm{~m}$ in length; it also had steep sides. According to Jackson (2004), a ramp was constructed on the south central side of the mound, leading down to the plaza and village, as part of the primary mound; Krieger (1946:213, fn42) also mentions a clay ramp on the south side of the mound, apparently associated with Zones I and J. Krieger (1946:211) considers each of these zones to represent two superimposed "flat-topped 'temple' mounds."

Subsequently, a second stage of the mound began to be constructed on the northern half of the primary mound platform. This stage, approximately $3.4 \mathrm{~m}$ in height and ca. $30 \mathrm{~m}$ in length, is comprised of eight stratified zones (A-H) (see Figure 6) with structures and other features. Each zone was subsequently buried by sandy loam and/or clay mound fill deposits. Krieger (1946:211) considered these mound deposits and burned structure zones to be "a huge mantle of midden refuse not intentionally built up," but it

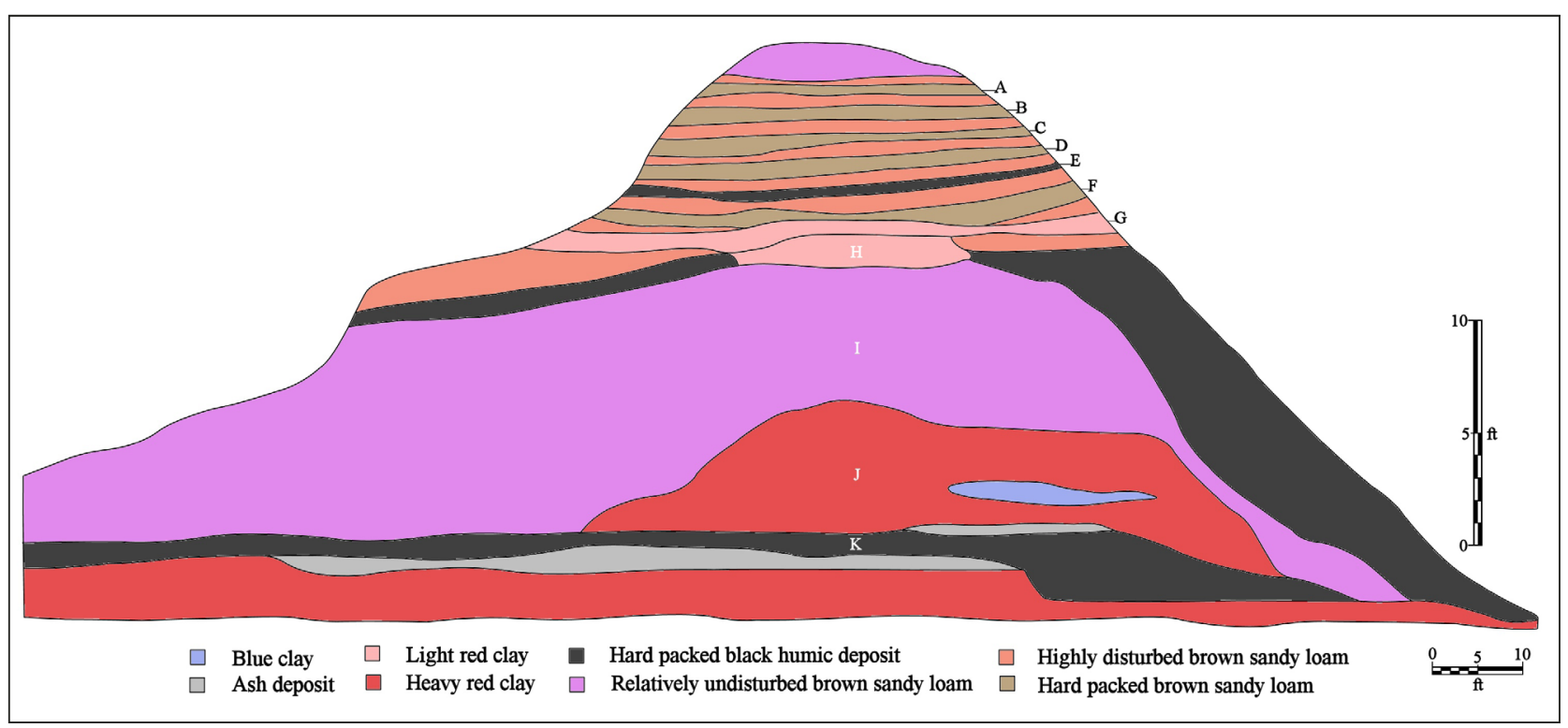

Figure 6. Cross-section of Zones A-K in the platform mound excavations at the Hatchel site. 
is clear that the mound zones represent the repeated construction and destruction of important structures that were built atop mound fill zones covering earlier structures and their associated debris. With the exception of one vessel from sub-mound Zone $\mathrm{K}$, the remainder of the ceramic vessels from the platform mound are from the second stage of mound construction and zones D-H.

SITE NAME OR SITE NUMBER: Hatchel (41BW3)

VESSEL NO.: F.S. 379, Zone D

VESSEL FORM: Jar; lower body and base section only

NON-PLASTICS AND PASTE: grog

RIM AND LIP FORM: N/A

CORE COLOR: $\mathrm{H}$ (fired in a reducing environment and cooled in the open air)

INTERIOR SURFACE COLOR: grayish-brown

EXTERIOR SURFACE COLOR: very dark grayish-brown; fire clouds on the body

WALL THICKNESS (IN MM): body, $6.1 \mathrm{~mm}$

INTERIOR SURFACE TREATMENT: smoothed

EXTERIOR SURFACE TREATMENT: smoothed

HEIGHT (IN CM): 10.0+

ORIFICE DIAMETER (IN CM): 17.8

DIAMETER AT BOTTOM OF RIM OR NECK

(IN CM): N/A

BASE DIAMETER (IN CM) AND SHAPE OF

BASE: $7.6 \mathrm{~cm}$; circular and flat

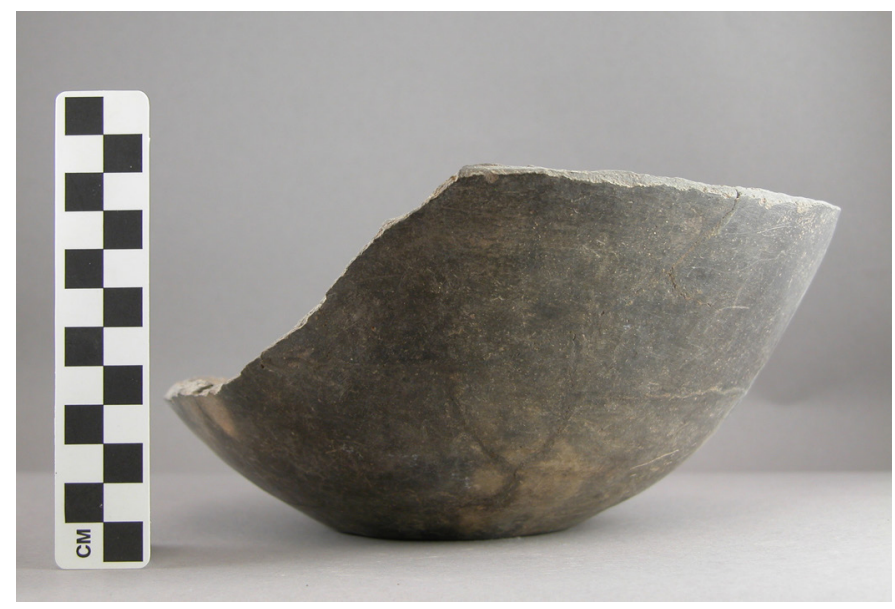

Figure 7. Lower body and base section of plain jar, F.S. 379 in Zone $D$ in the platform mound at the

ESTIMATED VOLUME (IN LITERS): $1.1+$ Hatchel site. Photograph courtesy of TARL.

DECORATION (INCLUDING MOTIF AND ELEMENTS WHEN APPARENT): Plain (Figure 7)

PIGMENT USE AND LOCATION ON VESSEL: none

TYPE AND VARIETY (IF KNOWN): Unidentified plain ware 
SITE NAME OR SITE NUMBER: Hatchel (41BW3)

VESSEL NO.: 6-3-188; Feature 12 in Zone D in the platform mound

VESSEL FORM: Jar

NON-PLASTICS AND PASTE: shell

RIM AND LIP FORM: Everted rim and rounded lip

CORE COLOR: B (fired and cooled in a reducing environment)

INTERIOR SURFACE COLOR: black

EXTERIOR SURFACE COLOR: black; fire clouds on the body

WALL THICKNESS (IN MM): rim, $3.8 \mathrm{~mm}$

INTERIOR SURFACE TREATMENT: burnished on the rim, smoothed on the body

EXTERIOR SURFACE TREATMENT: burnished

HEIGHT (IN CM): 9.5

ORIFICE DIAMETER (IN CM): 14.0

DIAMETER AT BOTTOM OF RIM OR NECK (IN CM): 10.8

BASE DIAMETER (IN CM) AND SHAPE OF BASE: 4.3; circular and rounded ESTIMATED VOLUME (IN LITERS): 0.8

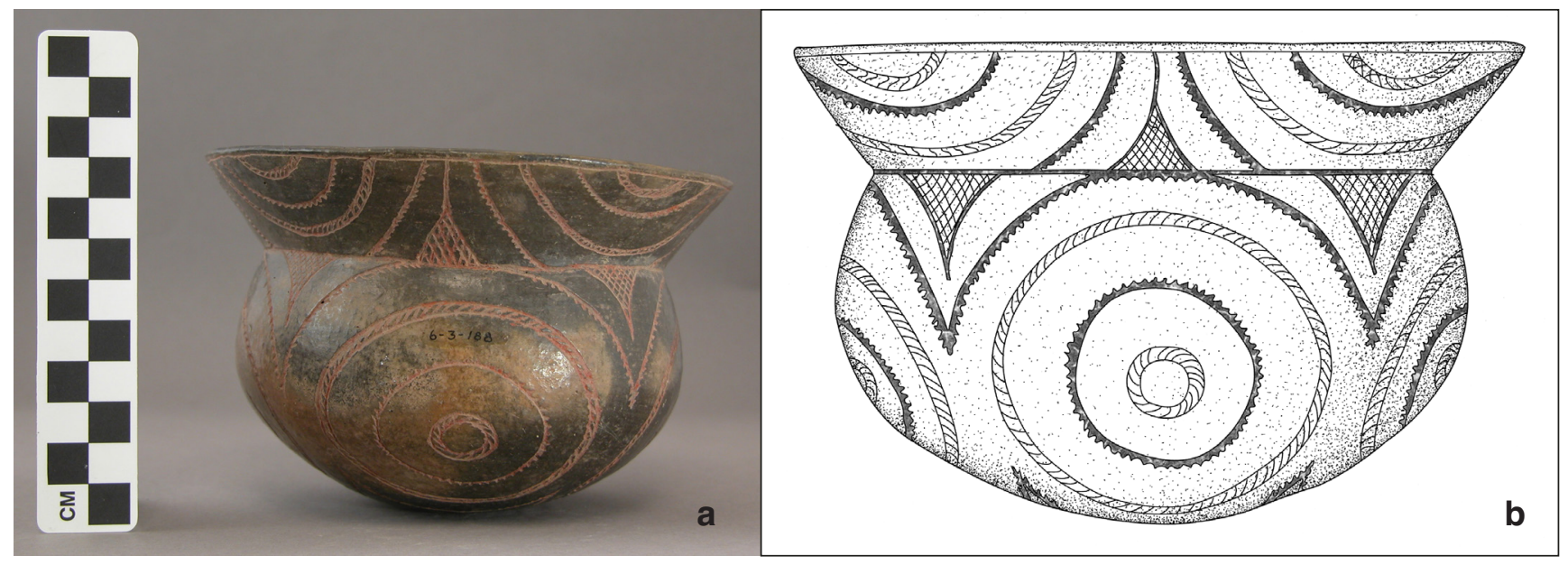

Figure 8. Black Avery Engraved jar (6-3-188) from Feature 12 in Zone D of the platform mound: a, photograph; b, redrawn from Laughlin (1940). Photograph courtesy of TARL. 
DECORATION (INCLUDING MOTIF AND ELEMENTS WHEN APPARENT): The rim and body of the vessel have different engraved motifs that are repeated four times around the vessel (Figure 8a-b). The rim has concentric semi-circles or narrow semi-circular zones filled with hatched lines; the central semicircular line has small downward-pointing tick marks. The repeating motif on the rim is divided by diagonal engraved lines with tick marks on either side of the semi-circular elements as well as a large cross-hatched pendant triangle and a vertical line that begins at the apex of the triangle element (Figure 8a-b).

The vessel body has four repeating sets of concentric circles or narrow circular zones that are either plain or filled with hatched lines (Figure 8a-b); the circular line has tick marks. Surrounding the circular elements are upper and lower semi-circular lines with tick marks as well as upper and lower cross-hatched engraved triangle elements.

PIGMENT USE AND LOCATION ON VESSEL: red pigment in engraved lines

TYPE AND VARIETY (IF KNOWN): Avery Engraved

SITE NAME OR SITE NUMBER: Hatchel (41BW3)

VESSEL NO.: 6-3-189, Burial 1 in Zone $\mathrm{E}$ in the platform mound

VESSEL FORM: Jar

NON-PLASTICS AND PASTE: grog

RIM AND LIP FORM: Direct rim and rounded lip

CORE COLOR: F (fired in a reducing environment and cooled in the open air)

INTERIOR SURFACE COLOR: reddish-brown

EXTERIOR SURFACE COLOR: dark yellowishbrown; fire clouds on the rim and body

WALL THICKNESS (IN MM): rim, $6.1 \mathrm{~mm}$

INTERIOR SURFACE TREATMENT: smoothed

EXTERIOR SURFACE TREATMENT: smoothed on the body

HEIGHT (IN CM): 11.5

ORIFICE DIAMETER (IN CM): 12.2

DIAMETER AT BOTTOM OF RIM OR NECK (IN CM): 12.0

BASE DIAMETER (IN CM) AND SHAPE OF

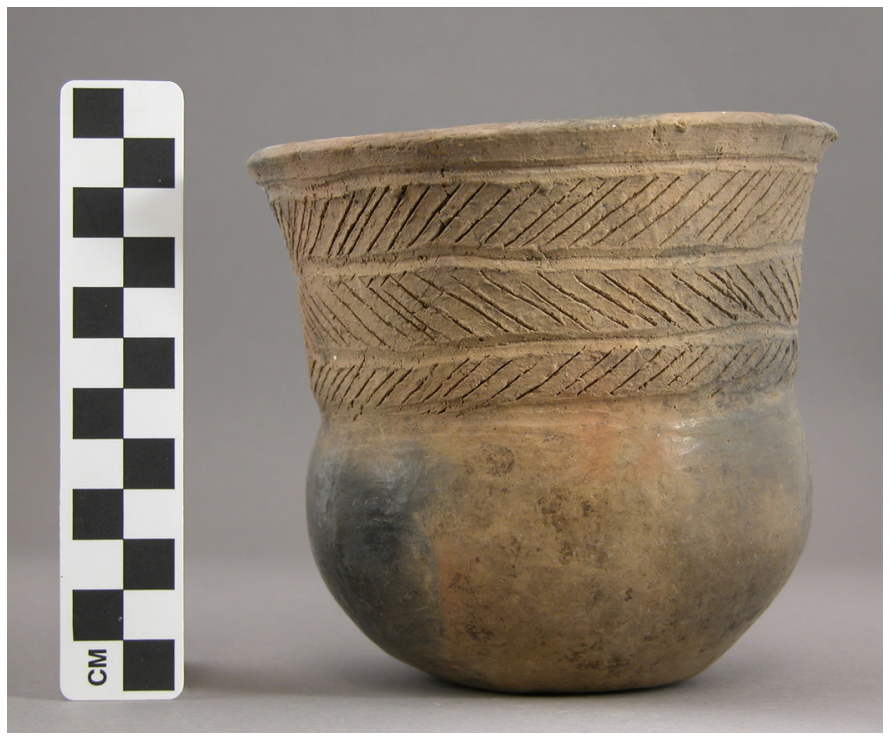

Figure 9. Foster Trailed-Incised jar (6-3-189) in Burial 1 in Zone $E$ in the platform mound at the Hatchel site. Photograph courtesy of TARL. 
BASE: 5.3; circular and flat

ESTIMATED VOLUME (IN LITERS): 0.84

DECORATION (INCLUDING MOTIF AND ELEMENTS WHEN APPARENT): The rim has three horizontal trailed panels filled with closely-spaced incised lines pitched in opposing directions (Figures 9 and 10c).

PIGMENT USE AND LOCATION ON VESSEL: none

TYPE AND VARIETY (IF KNOWN): Foster Trailed-Incised, var. unspecified

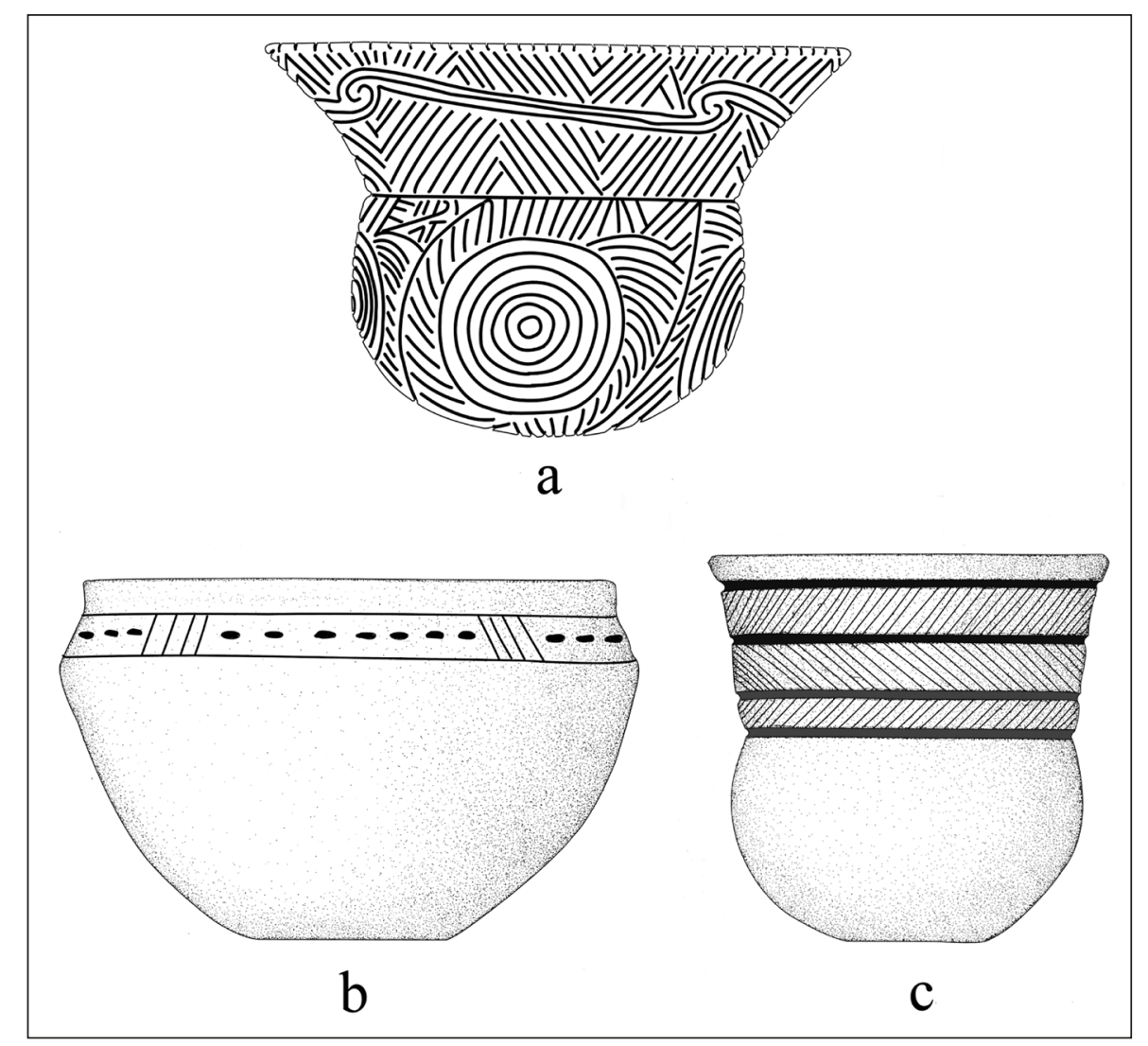

Figure 10. Drawings of vessels from Zone E, including Burial 1: a, Keno Trailed jar; b, Simms Engraved carinated bowl; c, Foster TrailedIncised, var. unspecified jar. Redrawn from Laughlin (1940). 
SITE NAME OR SITE NUMBER: Hatchel (41BW3)

VESSEL NO.: 6-3-190, Burial 1 in Zone $\mathrm{E}$ in the platform mound

VESSEL FORM: Jar

NON-PLASTICS AND PASTE: grog

RIM AND LIP FORM: Everted rim and rounded lip

CORE COLOR: B (fired and cooled in a reducing environment)

INTERIOR SURFACE COLOR: black

EXTERIOR SURFACE COLOR: black

WALL THICKNESS (IN MM): rim, 3.9 mm

INTERIOR SURFACE TREATMENT: smoothed

EXTERIOR SURFACE TREATMENT: burnished

HEIGHT (IN CM): 7.6

ORIFICE DIAMETER (IN CM): 11.5

DIAMETER AT BOTTOM OF RIM OR NECK

(IN CM): 7.1

BASE DIAMETER (IN CM) AND SHAPE OF

BASE: $2.0 \mathrm{~cm}$; circular and rounded

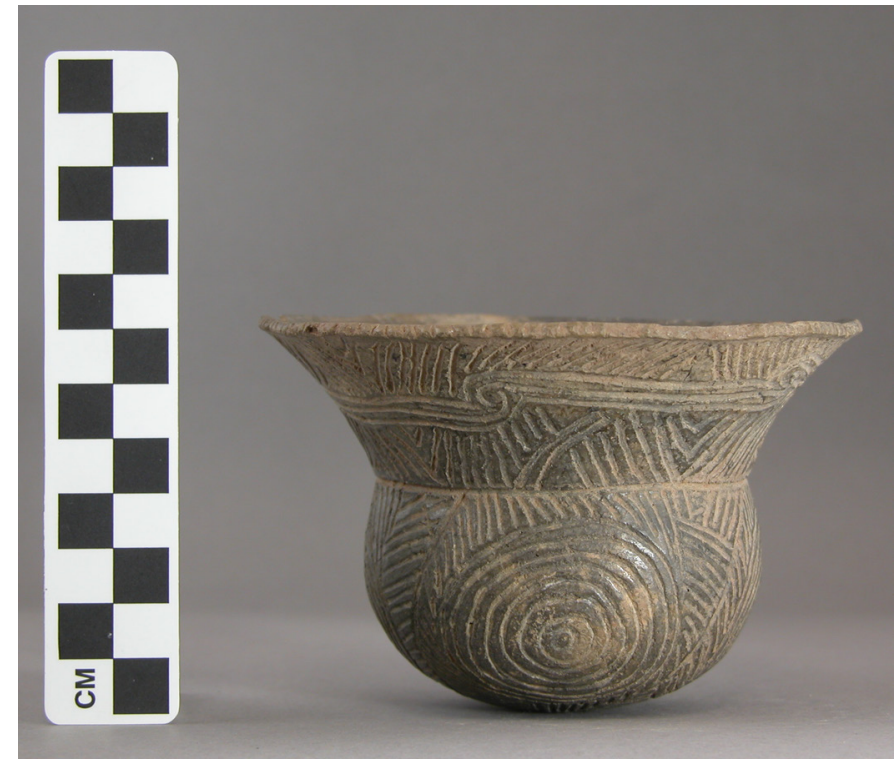

Figure 11. Keno Trailed jar (6-3-190) in Burial 1 in Zone $\mathrm{E}$ in the platform mound at the Hatchel site. Photograph courtesy of TARL.

ESTIMATED VOLUME (IN LITERS): 0.53

DECORATION (INCLUDING MOTIF AND ELEMENTS WHEN APPARENT): This vessel is decorated with trailed lines on the rim, body, and base (Figure 11; see also Figure 10a). The rim of the vessel has a set of three closely-spaced continuous meandering scroll elements at the mid-rim, with upper and lower sets of opposed and diagonal opposed trailed lines. The vessel body has four concentric trailed circles divided by diagonal and triangular-shaped areas filled with trailed lines. The vessel is also lip notched (Figure 11).

PIGMENT USE AND LOCATION ON VESSEL: none

TYPE AND VARIETY (IF KNOWN): Keno Trailed 
SITE NAME OR SITE NUMBER: Hatchel (41BW3)

VESSEL NO.: 6-3-191, Feature 14 in Zone E in the platform mound

VESSEL FORM: Carinated bowl

NON-PLASTICS AND PASTE: grog

RIM AND LIP FORM: Inverted-direct rim and rounded lip

CORE COLOR: $\mathrm{G}$ (fired in a reducing environment)

INTERIOR SURFACE COLOR: very dark gray; fire clouds on the rim

EXTERIOR SURFACE COLOR: yellowishbrown; fire clouds on the rim, body, and base

WALL THICKNESS (IN MM): rim, $4.6 \mathrm{~mm}$

INTERIOR SURFACE TREATMENT: smoothed

EXTERIOR SURFACE TREATMENT: smoothed

HEIGHT (IN CM): 10.8

ORIFICE DIAMETER (IN CM): 14.6

DIAMETER AT BOTTOM OF RIM OR NECK (IN CM): 15.3

BASE DIAMETER (IN CM) AND SHAPE OF

BASE: $6.8 \mathrm{~cm}$; circular and flat

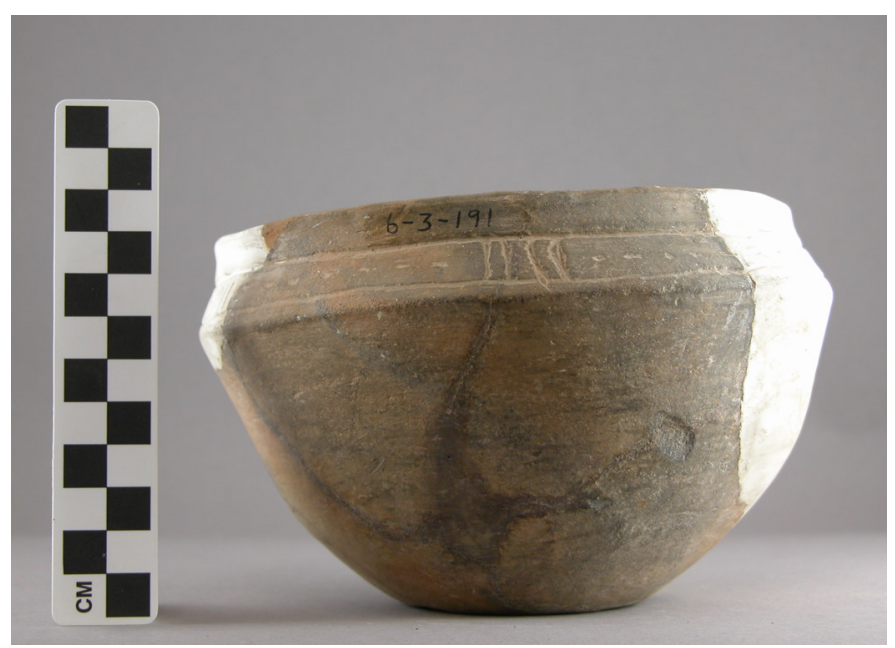

Figure 12. Simms Engraved carinated bowl (6-3-191) from Feature 14 in Zone $E$ of the platform mound at the Hatchel site. Photograph courtesy of TARL.

ESTIMATED VOLUME (IN LITERS): 0.95

DECORATION (INCLUDING MOTIF AND ELEMENTS WHEN APPARENT): The rim has four engraved panels divided by sets of four vertical to near-vertical engraved lines (Figure 12; see also Figure $10 \mathrm{~b})$. Each panel has a single horizontal row of excised punctations.

PIGMENT USE AND LOCATION ON VESSEL: none

TYPE AND VARIETY (IF KNOWN): Simms Engraved 
SITE NAME OR SITE NUMBER: Hatchel (41BW3)

VESSEL NO.: 6-3-193; Zone $\mathrm{F}$ in the platform mound

VESSEL FORM: Carinated bowl

NON-PLASTICS AND PASTE: grog

RIM AND LIP FORM: Inverted rim and rounded lip

CORE COLOR: $\mathrm{G}$ (fired in a reducing environment and cooled in the open air)

INTERIOR SURFACE COLOR: black

EXTERIOR SURFACE COLOR: dark yellowish-brown; fire clouds on the rim, body, and base

WALL THICKNESS (IN MM): rim, $4.5 \mathrm{~mm}$

INTERIOR SURFACE TREATMENT:

smoothed

EXTERIOR SURFACE TREATMENT: burnished

HEIGHT (IN CM): 4.1

ORIFICE DIAMETER (IN CM): 7.0

DIAMETER AT BOTTOM OF RIM OR NECK (IN CM): 8.1

BASE DIAMETER (IN CM) AND SHAPE OF BASE: 2.0; circular and flat

ESTIMATED VOLUME (IN LITERS): 0.17

DECORATION (INCLUDING MOTIF AND ELEMENTS WHEN APPARENT): Plain (Figure $13 a-b)$

PIGMENT USE AND LOCATION ON VESSEL: none

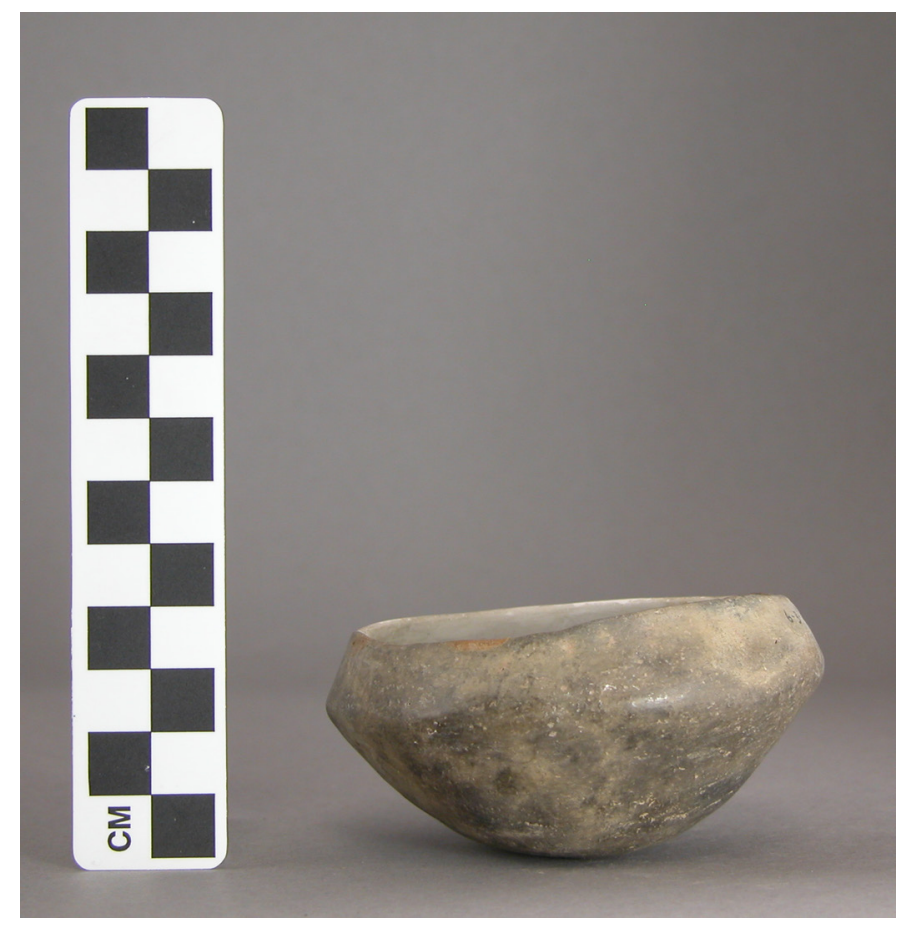

a

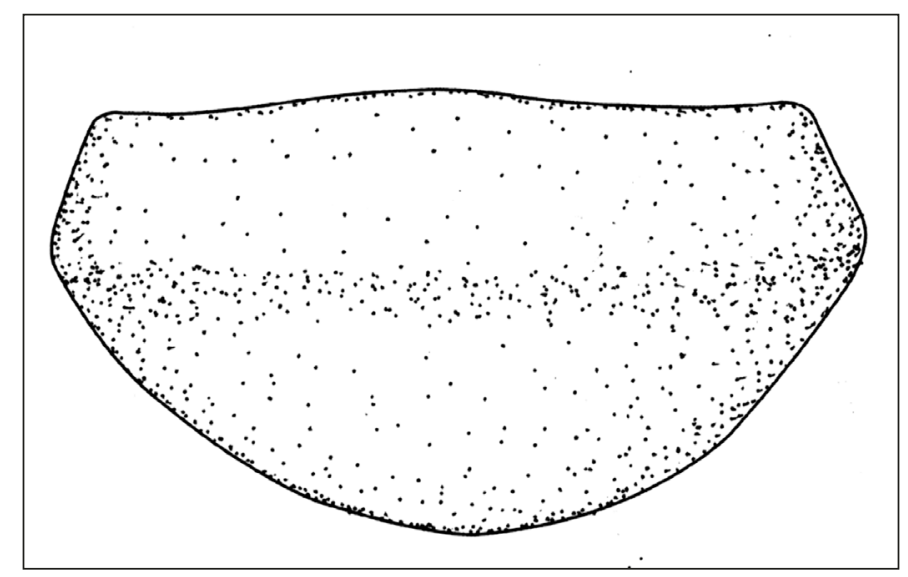

b

Figure 13. Plain carinated bowl (6-3-193) from Zone $F$ in the platform mound at the Hatchel site: a, photograph; b, drawing, redrawn from Laughlin (1940). Photograph courtesy of TARL.

TYPE AND VARIETY (IF KNOWN): Unidentified plain ware 
SITE NAME OR SITE NUMBER: Hatchel (41BW3)

VESSEL NO.: 6-3-194, Burial 2 in Zone F in the platform mound

VESSEL FORM: Carinated bowl

NON-PLASTICS AND PASTE: grog and bone

RIM AND LIP FORM: Direct rim and rounded $\operatorname{lip}$

CORE COLOR: B (fired and cooled in a reducing environment)

INTERIOR SURFACE COLOR: black

EXTERIOR SURFACE COLOR: very dark grayish-brown; fire clouds on the body

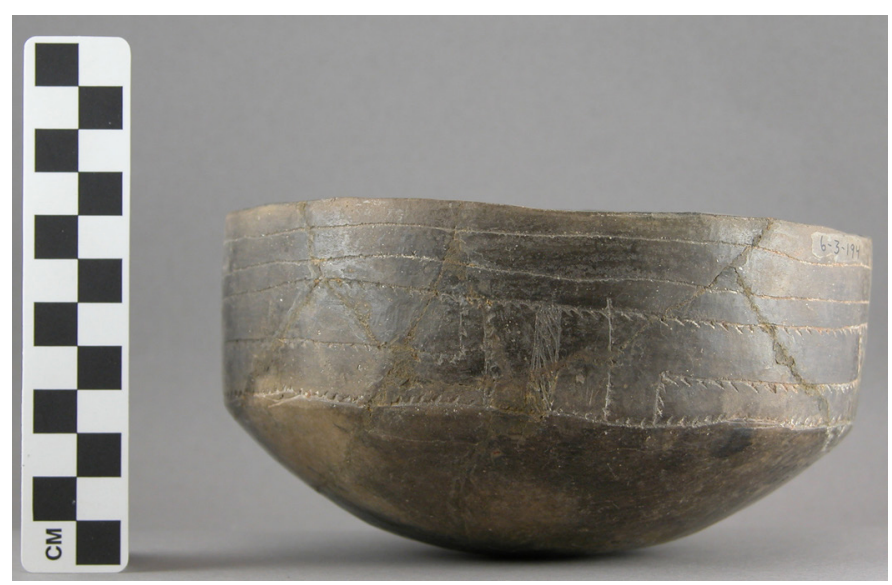

a

WALL THICKNESS (IN MM): rim, 4.7 mm

INTERIOR SURFACE TREATMENT: burnished

EXTERIOR SURFACE TREATMENT: burnished

HEIGHT (IN CM): 7.6

ORIFICE DIAMETER (IN CM): 15.3

DIAMETER AT BOTTOM OF RIM OR NECK (IN CM): 15.3

BASE DIAMETER (IN CM) AND SHAPE OF BASE: $6.4 \mathrm{~cm}$; circular and rounded

ESTIMATED VOLUME (IN LITERS): 0.70

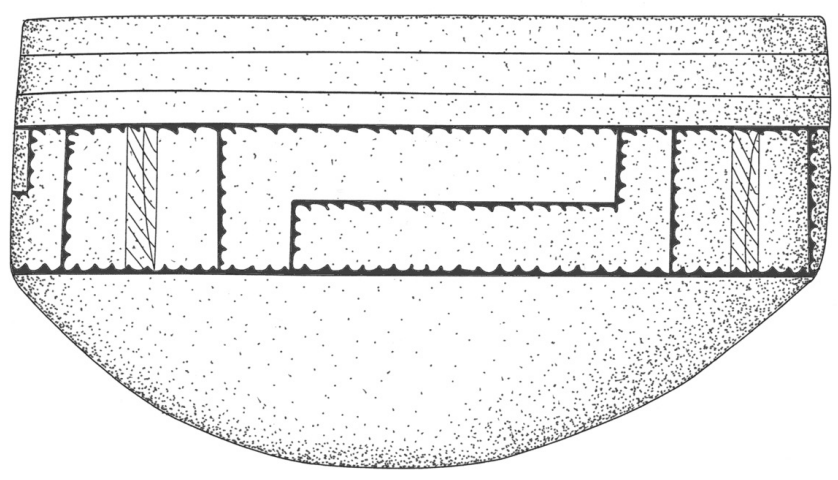

b

Figure 14. Barkman Engraved carinated bowl (6-3194 ) in Burial 2 , Zone $F$, in the platform mound at the Hatchel site: a, photograph, courtesy of TARL; b, drawing, redrawn from Laughlin (1940).

DECORATION (INCLUDING MOTIF AND ELEMENTS WHEN APPARENT): The rim has an engraved motif repeated four times around the vessel; above the motif are two horizontal engraved lines (Figure 14a-b). The engraved motif consists of a panel with an enclosed horizontal and vertical scroll line with downward-pointing excised tick marks; the upper and lower panel lines also have excised tick marks. On either side of the scroll line are single vertical engraved lines with excised tick marks as well as narrow vertical columns filled with diagonal hatched lines (Figure 14a-b).

PIGMENT USE AND LOCATION ON VESSEL: white pigment in the engraved lines

TYPE AND VARIETY (IF KNOWN): Barkman Engraved 
SITE NAME OR SITE NUMBER: Hatchel (41BW3)

VESSEL NO.: 6-3-195; Burial 2 in Zone $F$ in the platform mound

VESSEL FORM: Jar

NON-PLASTICS AND PASTE: grog

RIM AND LIP FORM: Everted rim and rounded $\operatorname{lip}$

CORE COLOR: $\mathrm{H}$ (fired in a reducing environment and cooled in the open air)

INTERIOR SURFACE COLOR: dark yellowishbrown; fire clouds on the rim, body, and base

EXTERIOR SURFACE COLOR: dark grayishbrown; fire clouds on the rim and body

WALL THICKNESS (IN MM): rim, $5.2 \mathrm{~mm}$

INTERIOR SURFACE TREATMENT: smoothed on the rim

EXTERIOR SURFACE TREATMENT: burnished on the body

HEIGHT (IN CM): 11.6

ORIFICE DIAMETER (IN CM): 13.3

DIAMETER AT BOTTOM OF RIM OR NECK (IN CM): 12.9

BASE DIAMETER (IN CM) AND SHAPE OF BASE: $6.4 \mathrm{~cm}$; circular and flat

\section{ESTIMATED VOLUME (IN LITERS): 0.92}

\section{DECORATION (INCLUDING MOTIF AND} ELEMENTS WHEN APPARENT): The rim is

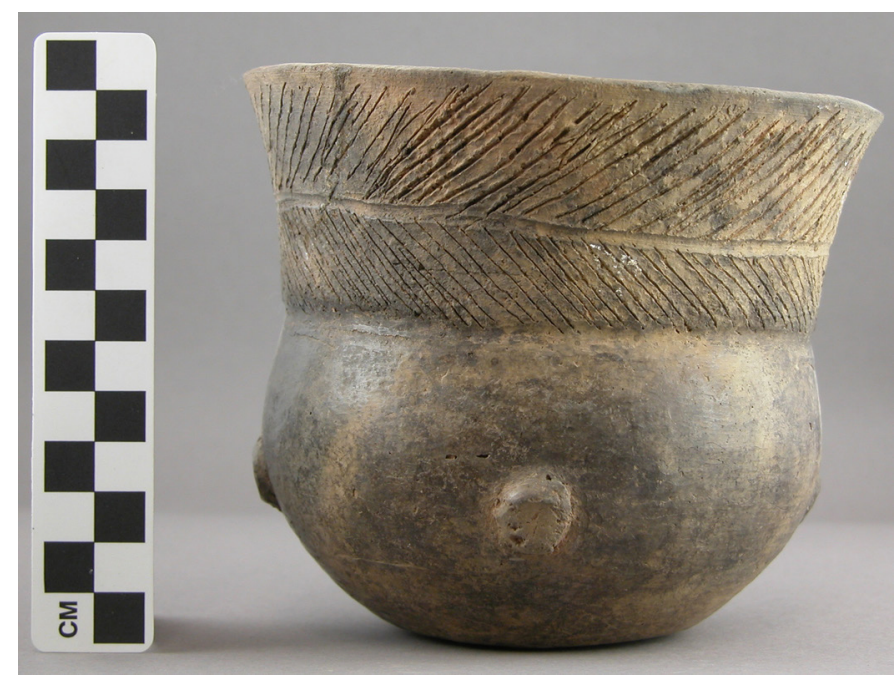

a

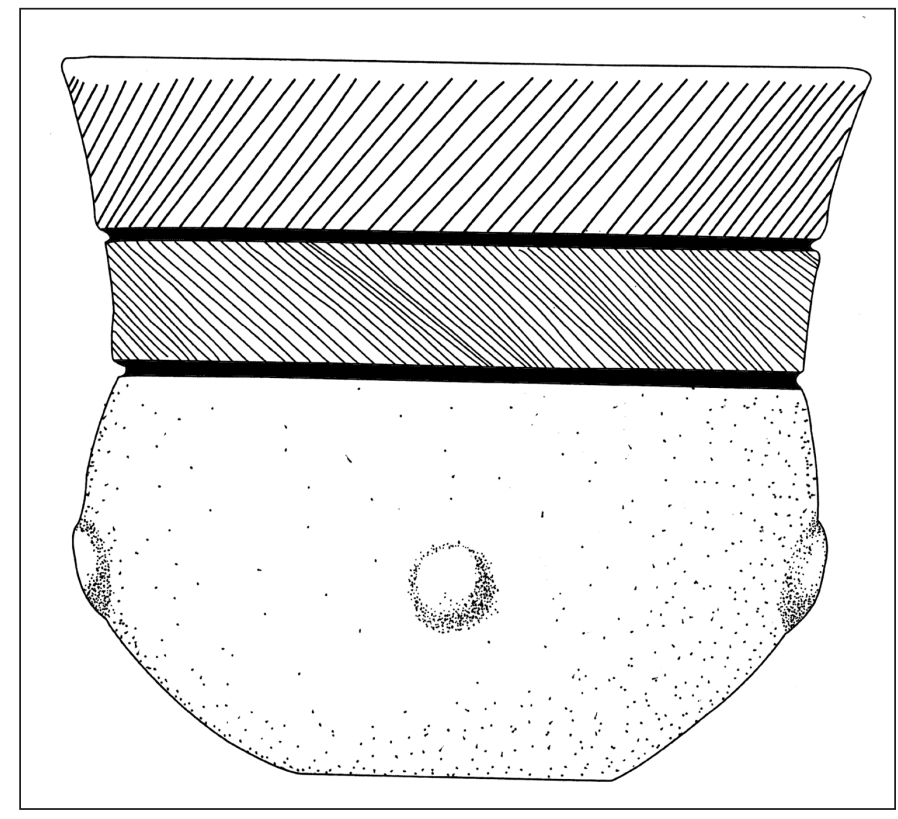

b

Figure 15. Foster Trailed-Incised, var. unspecified jar (6-3-195) in Burial 2 in Zone $F$ of the platform mound at the Hatchel site: a, photograph, courtesy of TARL; b, drawing, redrawn from Laughlin (1940).

divided into two horizontal panels by widely-spaced horizontal trailed lines. The panels are filled with closely-spaced diagonal incised lines pitched in opposite directions (Figure 15a-b). The vessel mid-body has four widely-spaced appliqued nodes; the nodes are $14 \mathrm{~mm}$ in diameter.

\section{PIGMENT USE AND LOCATION ON VESSEL:}

TYPE AND VARIETY (IF KNOWN): Foster Trailed-Incised, var. unspecified 
SITE NAME OR SITE NUMBER: Hatchel (41BW3)

VESSEL NO.: 6-3-196; Burial 2 in Zone $\mathrm{F}$ in the platform mound

VESSEL FORM: Jar

NON-PLASTICS AND PASTE: grog

RIM AND LIP FORM: Everted rim and rounded lip

CORE COLOR: $\mathrm{G}$ (fired in a reducing environment and cooled in the open air)

INTERIOR SURFACE COLOR: very dark grayish-brown; fire clouds on the base

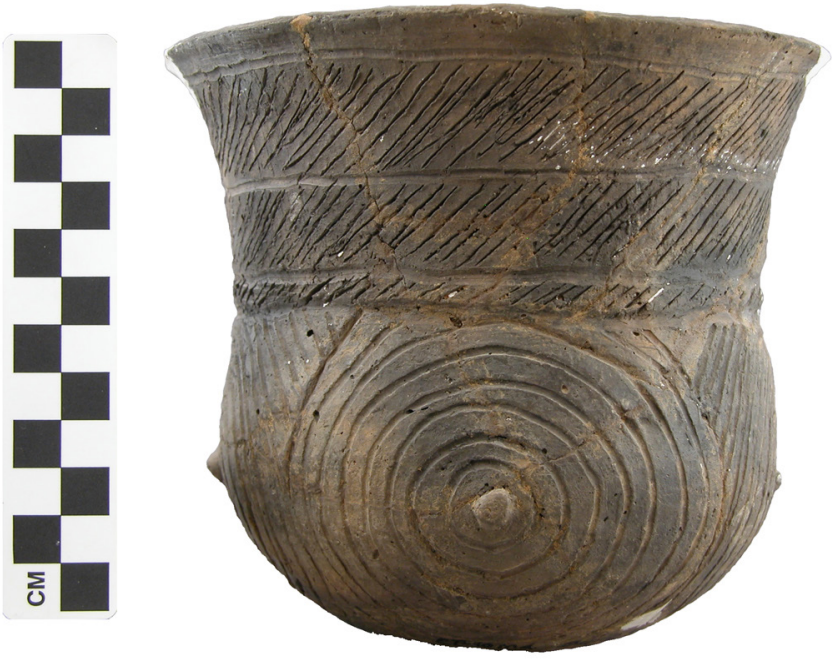

EXTERIOR SURFACE COLOR: dark yellowishbrown; fire clouds on the rim and body

WALL THICKNESS (IN MM): rim, 4.9 mm

INTERIOR SURFACE TREATMENT: smoothed

EXTERIOR SURFACE TREATMENT: none

HEIGHT (IN CM): 14.0

ORIFICE DIAMETER (IN CM): 15.2

DIAMETER AT BOTTOM OF RIM OR NECK (IN CM): 14.8

BASE DIAMETER (IN CM) AND SHAPE OF BASE: $7.0 \mathrm{~cm}$; circular and flat

\section{ESTIMATED VOLUME (IN LITERS): 1.3}

DECORATION (INCLUDING MOTIF AND ELEMENTS WHEN APPARENT): The rim is divided into three horizontal panels by trailed lines; the panels are filled with diagonal incised lines pitched in the same direction (Figure 16a-b). The vessel body

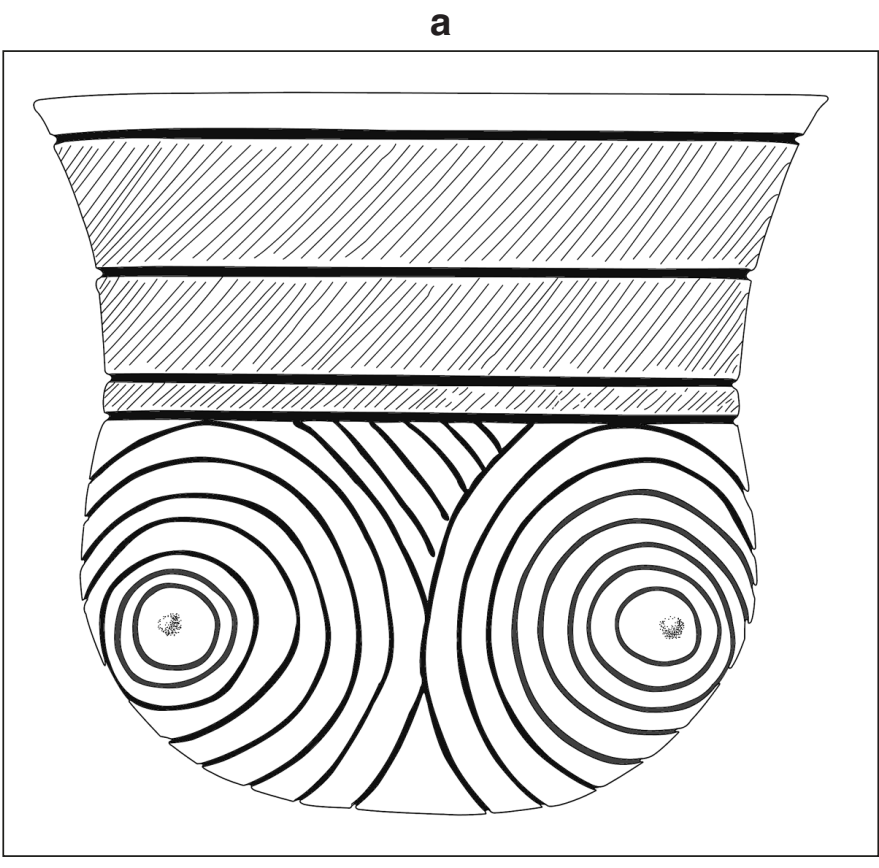

b

Figure 16. Foster Trailed-Incised, var. Red Lake jar (6-3-196) in Burial 2 in Zone $F$ in the platform mound at the Hatchel site: a, photograph, courtesy of TARL; b, drawing, redrawn from Laughlin (1940). has four repeated concentric trailed circles around small appliqued nodes. Dividing the concentric circles are upper and/or lower sets of diagonal and curvilinear lines forming triangular areas (Figure 16a-b).

PIGMENT USE AND LOCATION ON VESSEL: none

TYPE AND VARIETY (IF KNOWN): Foster Trailed-Incised, var. Red Lake (Schambach and Miller 1984:121 and Figure 11-10) 
SITE NAME OR SITE NUMBER: Hatchel (41BW3)

VESSEL NO.: 6-3-197; Zone F in the platform mound

VESSEL FORM: Carinated bowl

NON-PLASTICS AND PASTE: grog

RIM AND LIP FORM: Inverted rim and rounded $\operatorname{lip}$

CORE COLOR: B (fired and cooled in a reducing environment)

INTERIOR SURFACE COLOR: very dark grayish-brown

EXTERIOR SURFACE COLOR: very dark grayish-brown; fire clouds on the body

WALL THICKNESS (IN MM): rim, $4.3 \mathrm{~mm}$

INTERIOR SURFACE TREATMENT: burnished

EXTERIOR SURFACE TREATMENT: burnished

HEIGHT (IN CM): 7.0

ORIFICE DIAMETER (IN CM): 15.8

DIAMETER AT BOTTOM OF RIM OR NECK (IN CM): 16.2

BASE DIAMETER (IN CM) AND SHAPE OF BASE: $4.4 \mathrm{~cm}$; circular and rounded

ESTIMATED VOLUME (IN LITERS): 0.66

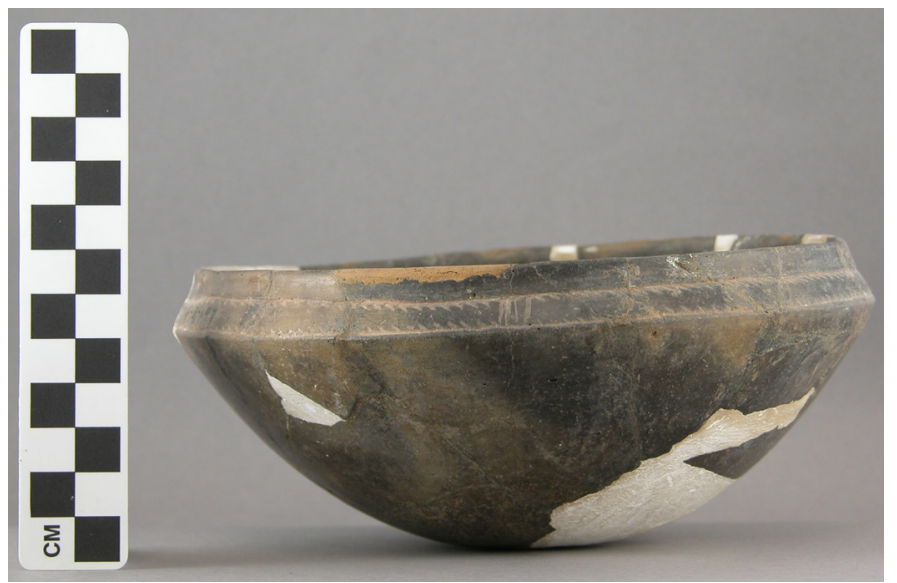

a

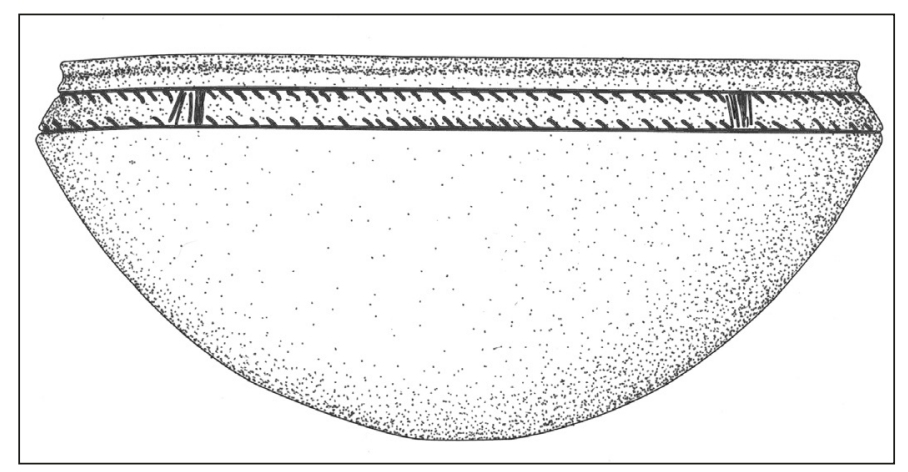

b

Figure 17. Simms Engraved carinated bowl (6-3-197) in Zone $\mathrm{F}$ of the platform mound at the Hatchel site: a, photograph, courtesy TARL; b, drawing, redrawn from Laughlin (1940).

DECORATION (INCLUDING MOTIF AND ELEMENTS WHEN APPARENT): The rim has a single horizontal engraved panel defined by single upper and lower horizontal engraved lines with upward- or downward-pointing excised tick marks (Figure 17a-b). The panel itself is divided into four sections by sets of four vertical engraved lines.

PIGMENT USE AND LOCATION ON VESSEL: none

TYPE AND VARIETY (IF KNOWN): Simms Engraved 
SITE NAME OR SITE NUMBER: Hatchel (41BW3)

VESSEL NO.: 6-3-198; Zone F in the platform mound

VESSEL FORM: Jar

NON-PLASTICS AND PASTE: grog

RIM AND LIP FORM: Everted rim and rounded lip

CORE COLOR: B (fired and cooled in a reducing environment)

INTERIOR SURFACE COLOR: very dark grayish-brown

EXTERIOR SURFACE COLOR: very dark grayish-brown; fire clouds on the body

WALL THICKNESS (IN MM): rim, $5.1 \mathrm{~mm}$

INTERIOR SURFACE TREATMENT: smoothed

EXTERIOR SURFACE TREATMENT: smoothed on the lowermost body

HEIGHT (IN CM): 16.5

ORIFICE DIAMETER (IN CM): 10.8

DIAMETER AT BOTTOM OF RIM OR NECK (IN CM): 10.0

BASE DIAMETER (IN CM) AND SHAPE OF BASE: $5.1 \mathrm{~cm}$; circular and flat

\section{ESTIMATED VOLUME (IN LITERS): 1.5}

\section{DECORATION (INCLUDING MOTIF AND ELEMENTS}

WHEN APPARENT): The vessel rim is decorated with closelyspaced diagonal incised lines pitched from right to left (Figure 18a-b). The vessel body has closely-spaced vertical incised lines that extend from the rim-body juncture to just above the vessel base.

PIGMENT USE AND LOCATION ON VESSEL: none

TYPE AND VARIETY (IF KNOWN): Karnack BrushedIncised

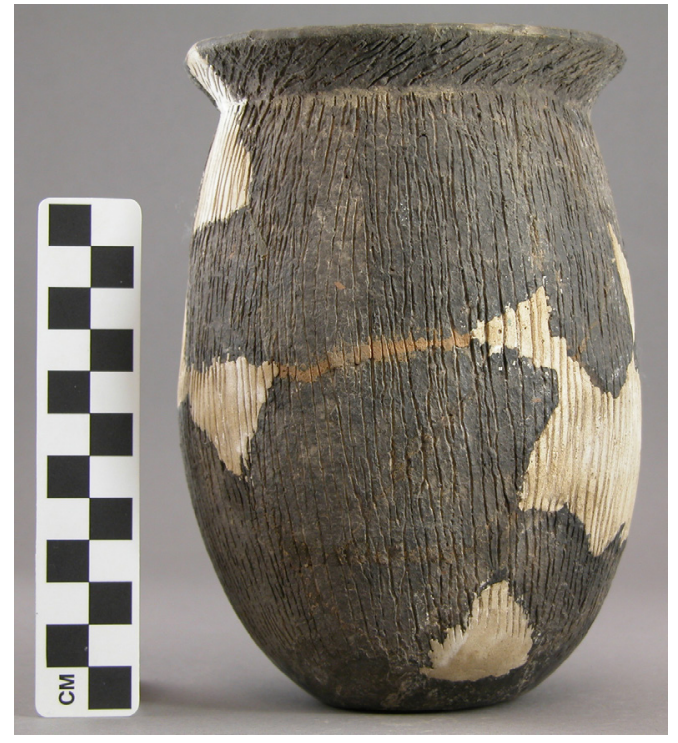

a

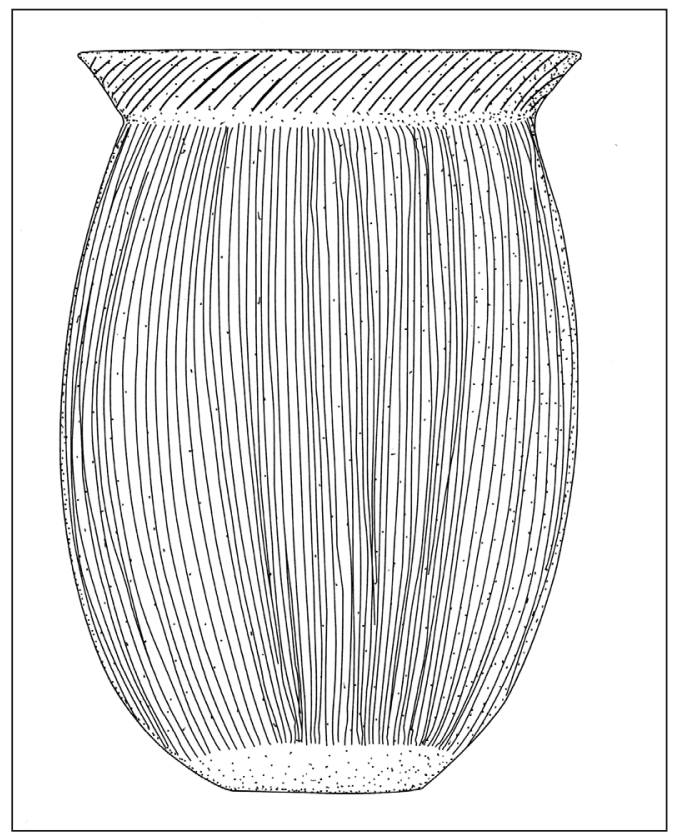

b

Figure 18. Karnack Brushed-Incised jar (6-3-198) in Zone $F$ of the platform mound at the Hatchel site: a, photograph, courtesy TARL; b, drawing, redrawn from Laughlin (1940). 
SITE NAME OR SITE NUMBER: Hatchel (41BW3)

VESSEL NO.: F.S. 754, Zone G in the platform mound

VESSEL FORM: Bowl

NON-PLASTICS AND PASTE: shell

RIM AND LIP FORM: Direct rim and rounded lip

CORE COLOR: B (fired and cooled in a reducing environment)

INTERIOR SURFACE COLOR: dark grayish-brown

EXTERIOR SURFACE COLOR: dark grayishbrown

WALL THICKNESS (IN MM): rim, $4.5 \mathrm{~mm}$

INTERIOR SURFACE TREATMENT: smoothed

EXTERIOR SURFACE TREATMENT: burnished

HEIGHT (IN CM): 3.7

ORIFICE DIAMETER (IN CM): 11.0

DIAMETER AT BOTTOM OF RIM OR NECK (IN CM): N/A

BASE DIAMETER (IN CM) AND SHAPE OF BASE: $3.7 \mathrm{~cm}$; circular and flat

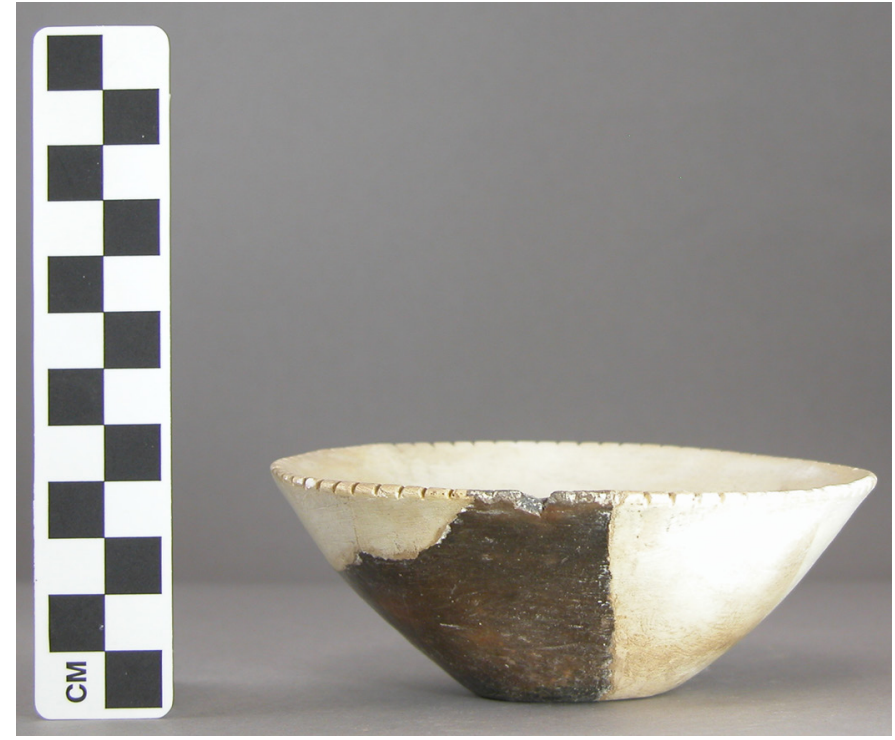

Figure 19. Lip-notched bowl (F.S. 754) in Zone G in the platform mound at the Hatchel site. Photograph courtesy of TARL.

ESTIMATED VOLUME (IN LITERS): 0.16

DECORATION (INCLUDING MOTIF AND ELEMENTS WHEN APPARENT): The vessel is plain, except for regular notching along the lip (Figure 19).

PIGMENT USE AND LOCATION ON VESSEL: none

TYPE AND VARIETY (IF KNOWN): Unidentified fine ware 
SITE NAME OR SITE NUMBER: Hatchel (41BW3)

VESSEL NO.: 6-3-199, Feature 22 in Zone G in the platform mound

VESSEL FORM: Jar

NON-PLASTICS AND PASTE: grog

RIM AND LIP FORM: Everted rim and rounded lip

CORE COLOR: $\mathrm{G}$ (fired in a reducing environment and cooled in the open air)

INTERIOR SURFACE COLOR: very dark grayish-brown

EXTERIOR SURFACE COLOR: dark yellowishbrown; fire clouds on the body and base

WALL THICKNESS (IN MM): rim, 5.4 mm; body, $6.2 \mathrm{~mm}$

INTERIOR SURFACE TREATMENT: smoothed

EXTERIOR SURFACE TREATMENT:

smoothed on the body

HEIGHT (IN CM): 9.5

ORIFICE DIAMETER (IN CM): 13.2

DIAMETER AT BOTTOM OF RIM OR NECK (IN CM): 12.6

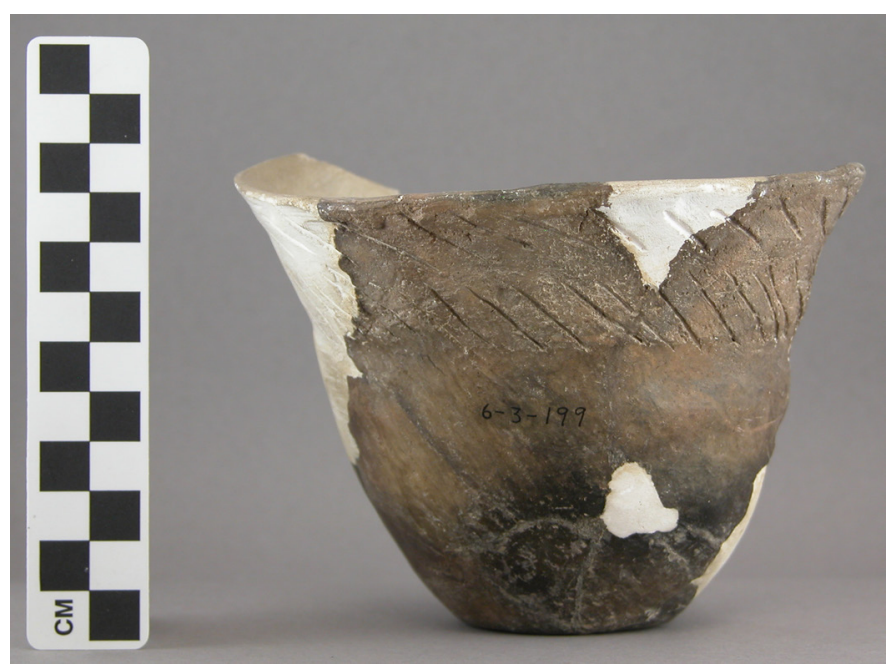

Figure 20. Incised jar (6-3-199) in Feature 22 in Zone $\mathbf{G}$ in the platform mound at the Hatchel site. Photograph courtesy of TARL.

BASE DIAMETER (IN CM) AND SHAPE OF BASE: $4.8 \mathrm{~cm}$; circular and flat ESTIMATED VOLUME (IN LITERS): 0.75

DECORATION (INCLUDING MOTIF AND ELEMENTS WHEN APPARENT): The rim is decorated with two horizontal rows of left-to-right drawn diagonal incised lines (Figure 20).

PIGMENT USE AND LOCATION ON VESSEL: none

TYPE AND VARIETY (IF KNOWN): Unidentified utility ware 
SITE NAME OR SITE NUMBER: Hatchel (41BW3)

VESSEL NO.: 6-3-200; Burial 3 in Zone $\mathrm{H}$ in the platform mound

VESSEL FORM: Compound bowl

NON-PLASTICS AND PASTE: grog

RIM AND LIP FORM: Everted rim and rounded lip

CORE COLOR: A (fired and cooled in an oxidizing environment)

INTERIOR SURFACE COLOR: red

EXTERIOR SURFACE COLOR: red; fire clouds on the base

WALL THICKNESS (IN MM): rim, $5.1 \mathrm{~mm}$

INTERIOR SURFACE TREATMENT: smoothed

EXTERIOR SURFACE TREATMENT: burnished

HEIGHT (IN CM): 15.8

ORIFICE DIAMETER (IN CM): 20.4

DIAMETER AT BOTTOM OF RIM OR NECK

(IN CM): 20.2

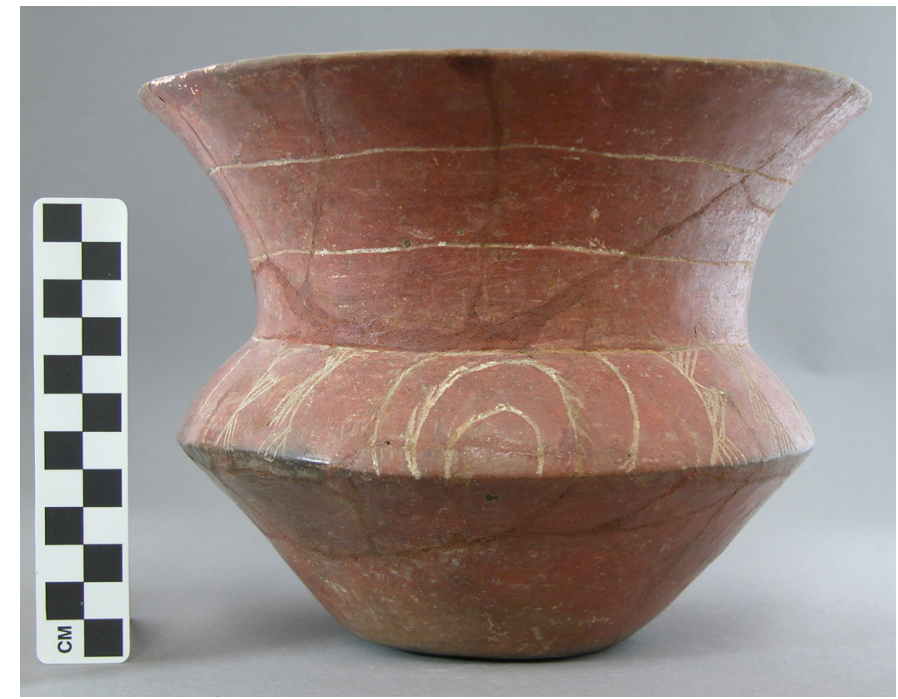

Figure 21. Avery Engraved, var. Bradshaw compound bowl (6-3-200) from Burial 3 in Zone $H$ of the platform mound at the Hatchel site. Photograph courtesy of TARL.

BASE DIAMETER (IN CM) AND SHAPE OF BASE: $8.0 \mathrm{~cm}$; circular and flat

\section{ESTIMATED VOLUME (IN LITERS): 2.6}

DECORATION (INCLUDING MOTIF AND ELEMENTS WHEN APPARENT): The vessel has a red slip on both interior and exterior vessel surfaces. On the upper panel on the exterior surface, the vessel is decorated with three widely-spaced horizontal engraved lines (Figures 21 and 22a). On the lower panel are four repeated sets of three concentric engraved semi-circles; the central concentric engraved line has dashed or spurred lines. The concentric semi-circle elements are divided by engraved brackets filled with diagonal lines, diagonal lines within triangular elements, and sets of concentric curvilinear engraved lines (Figures 21 and 22a).

PIGMENT USE AND LOCATION ON VESSEL: white pigment in the engraved designs

TYPE AND VARIETY (IF KNOWN): Avery Engraved, var. Bradshaw (see Schambach and Miller 1984:119) 


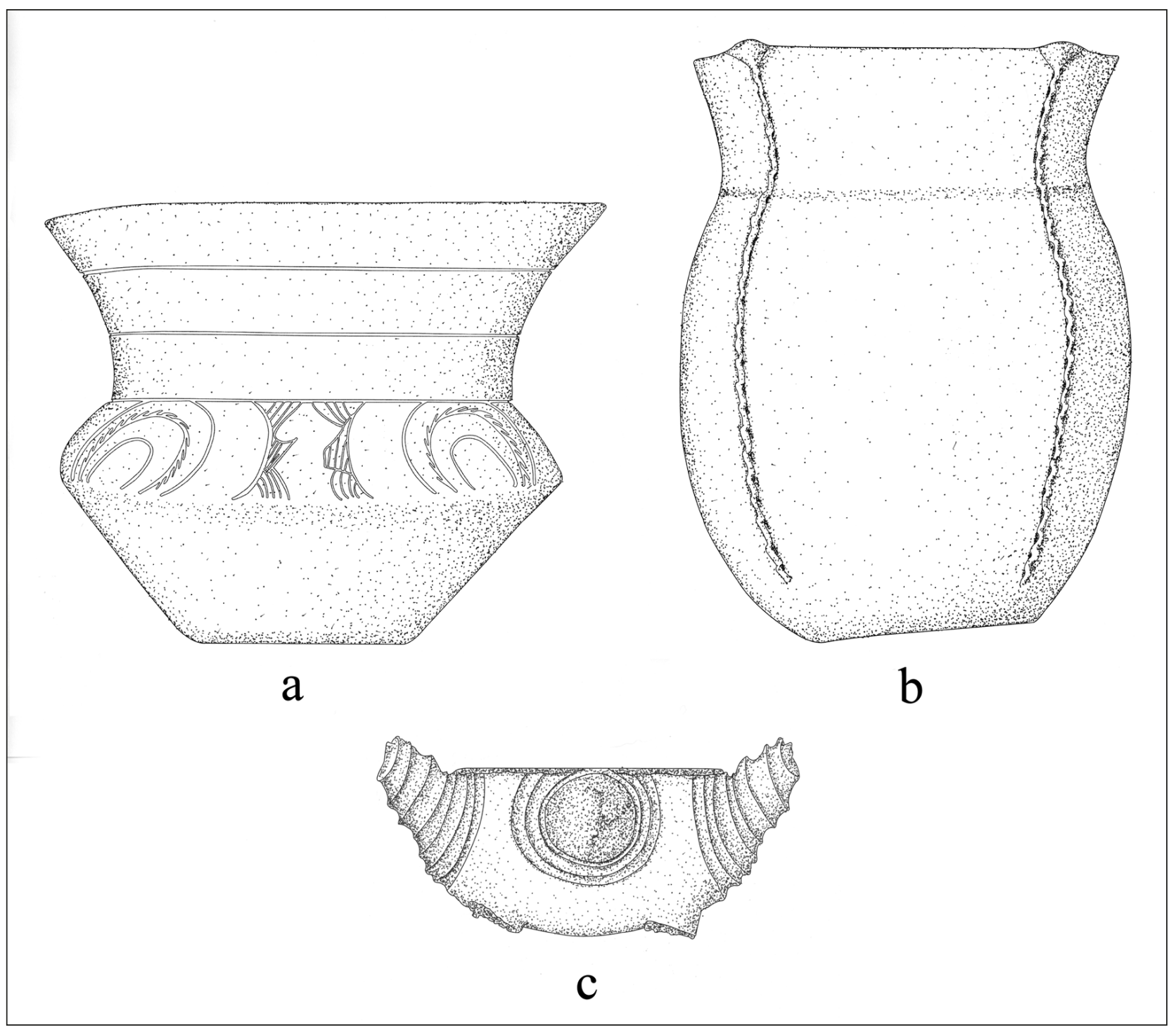

Figure 22. Vessels from Burial 3 in Zone H: a, Avery Engraved, var. Bradshaw compound bowl; b, McKinney Plain jar; c, appliqued bowl with broken pedestal legs. Redrawn from Laughlin (1940). 
SITE NAME OR SITE NUMBER: Hatchel (41BW3)

VESSEL NO.: 6-3-201; Burial 3 in Zone $\mathrm{H}$ of the platform mound

VESSEL FORM: Jar with four small rim peaks or lip tabs (Figure 23; see also Figure 22b)

NON-PLASTICS AND PASTE: grog

RIM AND LIP FORM: Everted rim and rounded lip

CORE COLOR: F (fired in a reducing environment and cooled in the open air)

INTERIOR SURFACE COLOR: reddish-brown; fire clouds on the rim and body

EXTERIOR SURFACE COLOR: reddish-brown; fire clouds on the rim, body, and base

WALL THICKNESS (IN MM): rim, $5.8 \mathrm{~mm}$

INTERIOR SURFACE TREATMENT: smoothed

EXTERIOR SURFACE TREATMENT:

smoothed on the body

HEIGHT (IN CM): 20.5

ORIFICE DIAMETER (IN CM): 15.2

DIAMETER AT BOTTOM OF RIM OR NECK (IN CM): 14.6

BASE DIAMETER (IN CM) AND SHAPE OF BASE: $8.0 \mathrm{~cm}$; circular and flat

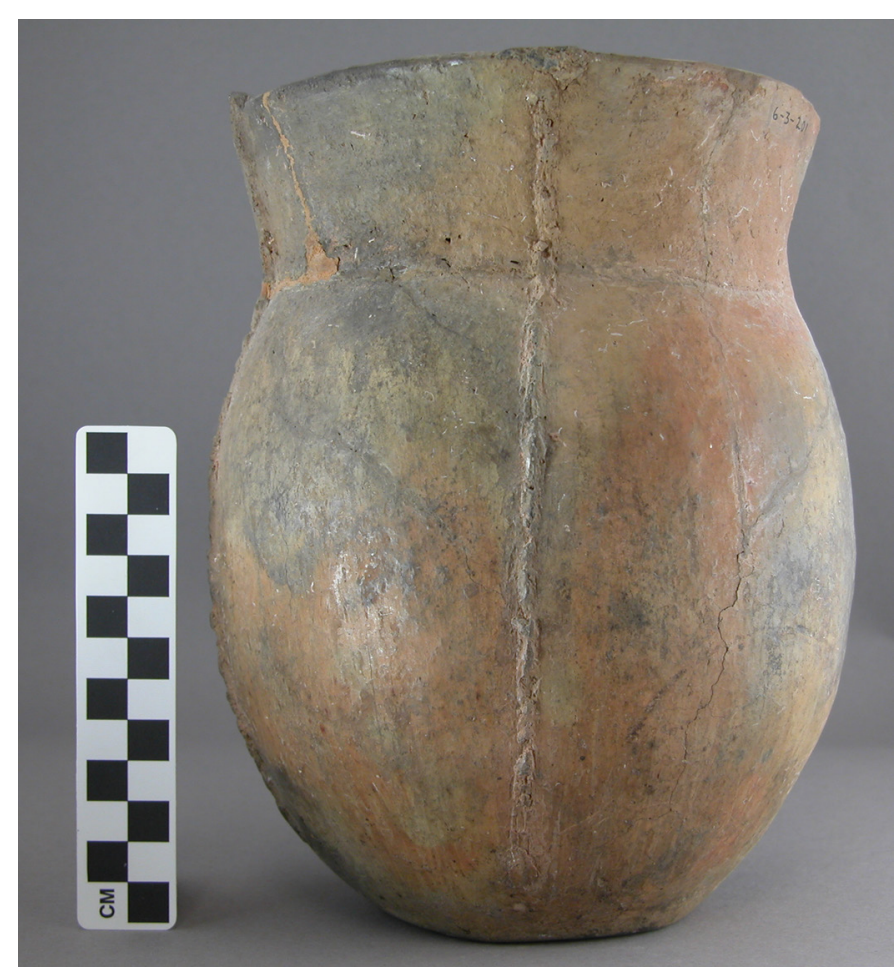

Figure 23. McKinney Plain jar (6-3-201) in Burial 3 in Zone $\mathrm{H}$ in the platform mound at the Hatchel site. Photograph courtesy of TARL.

ESTIMATED VOLUME (IN LITERS): 2.8

DECORATION (INCLUDING MOTIF AND ELEMENTS WHEN APPARENT): The vessel rim has been roughened, and there are also four equally-spaced vertical appliqued ridges extending from the rim peaks/lip tabs to within $1.2 \mathrm{~cm}$ of the vessel base (Figure 23; see also Figure 22b).

PIGMENT USE AND LOCATION ON VESSEL: none

TYPE AND VARIETY (IF KNOWN): McKinney Plain 
SITE NAME OR SITE NUMBER: Hatchel (41BW3)

VESSEL NO.: 6-3-202; Burial 3 in Zone $\mathrm{H}$ in the platform mound

VESSEL FORM: Bowl with four legs in a pedestal base

NON-PLASTICS AND PASTE: grog and bone

RIM AND LIP FORM: Inverted rim and rounded lip

CORE COLOR: B (fired and cooled in a reducing environment)

INTERIOR SURFACE COLOR: black

EXTERIOR SURFACE COLOR: very dark grayish-brown; fire clouds on the body

WALL THICKNESS (IN MM): rim, $4.9 \mathrm{~mm}$

INTERIOR SURFACE TREATMENT:

smoothed

EXTERIOR SURFACE TREATMENT:

smoothed on the base

HEIGHT (IN CM): 7.0

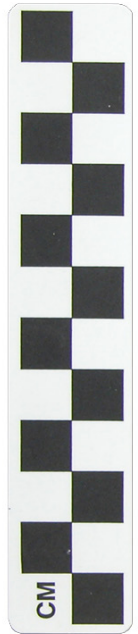

ORIFICE DIAMETER (IN CM): 8.0

DIAMETER AT BOTTOM OF RIM OR

NECK (IN CM): N/A

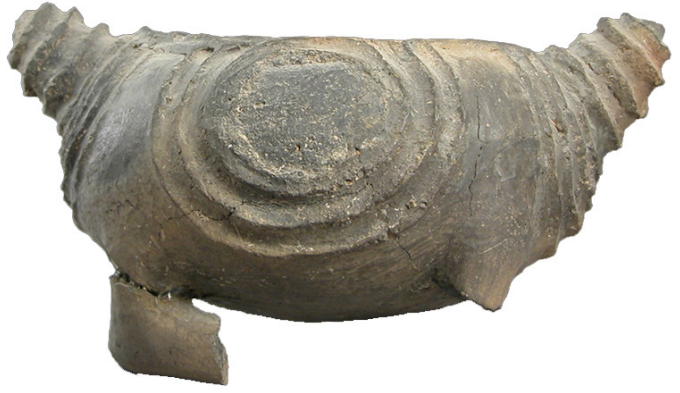

Figure 24. Appliqued bowl with pedestal legs (6-3-202) in Burial 3 in Zone $\mathbf{H}$ in the platform mound at the Hatchel site. Photograph courtesy of TARL.

BASE DIAMETER (IN CM) AND SHAPE OF BASE: 7.6; circular and round

ESTIMATED VOLUME (IN LITERS): 0.22

DECORATION (INCLUDING MOTIF AND ELEMENTS WHEN APPARENT): The vessel has four appliqued knobs (two have fallen off), $29 \mathrm{~mm}$ in diameter, and each knob (25 $\mathrm{mm}$ in height) is comprised of six concentric appliqued ridges (Figure 24; see also Figure 22c). There are four concentric appliqued ridge semi-circles around each appliqued knob. The legs (three of which have fallen off) are between 19$21 \mathrm{~mm}$ in diameter.

PIGMENT USE AND LOCATION ON VESSEL: none

TYPE AND VARIETY (IF KNOWN): Unidentified appliqued vessel (see Suhm and Jelks 1962:Plate 26c; Webb 1959:Figure 122p) with four pedestal legs 
SITE NAME OR SITE NUMBER: Hatchel (41BW3)

VESSEL NO.: F.S. 1349, Burial 3 in Zone $\mathrm{H}$ in the platform mound

VESSEL FORM: Carinated bowl; vessel broken at and immediately above the carination

NON-PLASTICS AND PASTE: grog

RIM AND LIP FORM: N/A

CORE COLOR: B (fired and cooled in a reducing environment)

INTERIOR SURFACE COLOR: dark grayish-brown

EXTERIOR SURFACE COLOR: very dark grayish-brown

WALL THICKNESS (IN MM): body, $6.9 \mathrm{~mm}$

INTERIOR SURFACE TREATMENT: smoothed

EXTERIOR SURFACE TREATMENT: burnished; organic residue on the vessel body

HEIGHT (IN CM): 13.3+

ORIFICE DIAMETER (IN CM): 24.8

DIAMETER AT BOTTOM OF RIM OR NECK (IN CM): 24.8

BASE DIAMETER (IN CM) AND SHAPE OF BASE: 8.9; circular and flat

ESTIMATED VOLUME (IN LITERS): 2.9+

DECORATION (INCLUDING MOTIF AND ELEMENTS WHEN APPARENT): Unidentified engraved elements on the lowermost part of the rim panel.

PIGMENT USE AND LOCATION ON VESSEL: red pigment in the engraved lines

TYPE AND VARIETY (IF KNOWN): Unidentified fine ware 
SITE NAME OR SITE NUMBER: Hatchel (41BW3)

VESSEL NO.: F.S. 993/994; Zone H in the platform mound (80L4).

VESSEL FORM: Olla

NON-PLASTICS AND PASTE: grog

RIM AND LIP FORM: N/A

CORE COLOR: F (fired in a reducing environment and cooled in the open air)

INTERIOR SURFACE COLOR: grayish-brown

EXTERIOR SURFACE COLOR: brown; fire clouds on the rim and body

WALL THICKNESS (IN MM): rim, $7.5 \mathrm{~mm}$; body, $7.5 \mathrm{~mm}$

INTERIOR SURFACE TREATMENT: none

EXTERIOR SURFACE TREATMENT: burnished

HEIGHT (IN CM): 30.3+

ORIFICE DIAMETER (IN CM): 5.2

DIAMETER AT BOTTOM OF RIM OR NECK (IN CM): 7.1; maximum body diameter is $31.8 \mathrm{~cm}$

BASE DIAMETER (IN CM) AND SHAPE OF BASE: N/A

ESTIMATED VOLUME (IN LITERS): N/A

DECORATION (INCLUDING MOTIF AND ELEMENTS WHEN APPARENT): The top of the vessel body has three horizontal engraved lines and at least two (but possibly as many as eight) large engraved pendant triangles (Figure 25). These pendant triangles have a single concentric semi-circle element and the apex of the triangles has an excised triangle element.

PIGMENT USE AND LOCATION ON VESSEL: red pigment in engraved lines

TYPE AND VARIETY (IF KNOWN): Unidentified fine ware

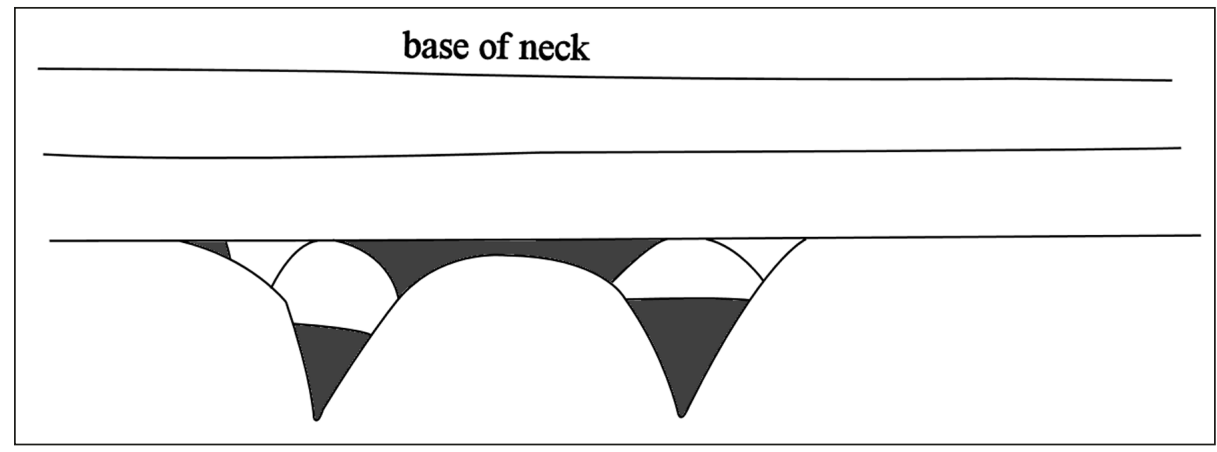

Figure 25. Decorative element on engraved olla (F.S. 993/994) in Zone H in the platform mound at the Hatchel site. 
SITE NAME OR SITE NUMBER: Hatchel (41BW3)

VESSEL NO.: F.S. 1297, Zone H in the platform mound (Features 19 and 20)

VESSEL FORM: Carinated bowl

NON-PLASTICS AND PASTE: grog

RIM AND LIP FORM: Inverted-direct rim and rounded lip

CORE COLOR: B (fired and cooled in a reducing environment)

INTERIOR SURFACE COLOR: black

EXTERIOR SURFACE COLOR: black

WALL THICKNESS (IN MM): rim, $4.6 \mathrm{~mm}$; body, $4.2 \mathrm{~mm}$

INTERIOR SURFACE TREATMENT: burnished

EXTERIOR SURFACE TREATMENT: burnished

HEIGHT (IN CM): N/A; rim panel is $3.0 \mathrm{~cm}$ in height

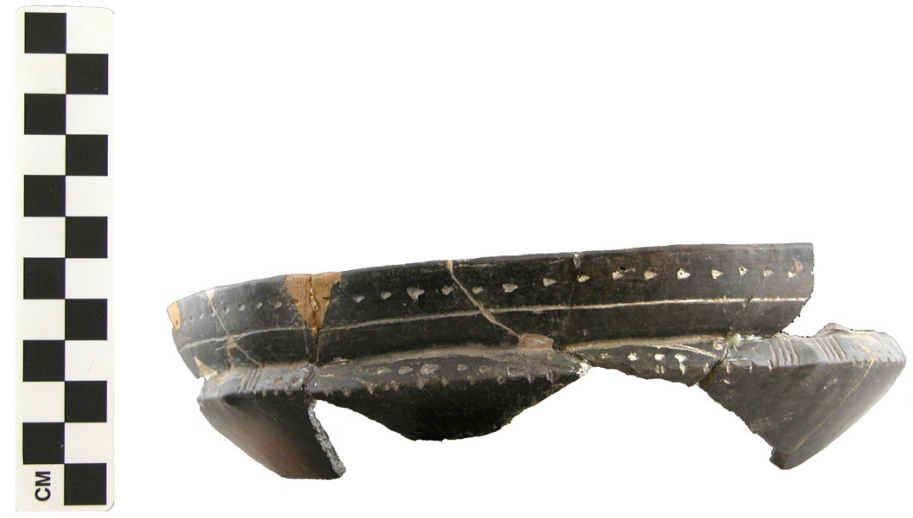

Figure 26. Belcher Engraved, var. Belcher carinated bowl section (F.S. 1297) in Features 19 and 20 in Zone $\mathrm{H}$ in the platform mound at the Hatchel site.

ORIFICE DIAMETER (IN CM): 20.3

DIAMETER AT BOTTOM OF RIM OR NECK (IN CM): 20.1

BASE DIAMETER (IN CM) AND SHAPE OF BASE: N/A

ESTIMATED VOLUME (IN LITERS): N/A

DECORATION (INCLUDING MOTIF AND ELEMENTS WHEN APPARENT): The rim is divided into three panels: (1) the upper panel is defined by a single horizontal engraved line and has a single central row of excised punctations; (2) the middle panel is plain; and (3) the lower panel, above the carination, has four quadrating appliqued nodes $(10 \mathrm{~mm}$ in diameter and $6 \mathrm{~mm}$ in height) surrounded by sets of four curvilinear engraved lines (Figure 26). Between the appliqued nodes are a series of zones defined by diagonal engraved lines, and each of these zones are filled with two rows of excised punctations.

PIGMENT USE AND LOCATION ON VESSEL: none

TYPE AND VARIETY (IF KNOWN): Belcher Engraved, var. Belcher (Schambach and Miller 1984:120) 
SITE NAME OR SITE NUMBER: Hatchel (41BW3)

VESSEL NO.: F.S. 1432; under Zone H in the platform mound

VESSEL FORM: Carinated bowl

NON-PLASTICS AND PASTE: grog

RIM AND LIP FORM: Inverted rim and rounded lip

CORE COLOR: $\mathrm{G}$ (fired in a reducing environment and cooled in the open air)

INTERIOR SURFACE COLOR: grayish-brown

EXTERIOR SURFACE COLOR: dark reddish-brown; fire clouds on the rim and body

WALL THICKNESS (IN MM): rim, $5.6 \mathrm{~mm}$

INTERIOR SURFACE TREATMENT: smoothed

EXTERIOR SURFACE TREATMENT: burnished

HEIGHT (IN CM): 16.3

ORIFICE DIAMETER (IN CM): 24.8

DIAMETER AT BOTTOM OF RIM OR NECK (IN CM): 22.8

BASE DIAMETER (IN CM) AND SHAPE OF BASE: 10.2; circular and flat

ESTIMATED VOLUME (IN LITERS): 4.6

DECORATION (INCLUDING MOTIF AND ELEMENTS WHEN APPARENT): The upper part of the rim has two horizontal engraved lines above rectangular panels repeated four times around the vessel (Figure 27). The panels have two horizontal engraved lines with diagonal spurs; the panels have curvilinear ends and are divided by a single near vertical engraved line.

PIGMENT USE AND LOCATION ON VESSEL: none

TYPE AND VARIETY (IF KNOWN): Barkman Engraved

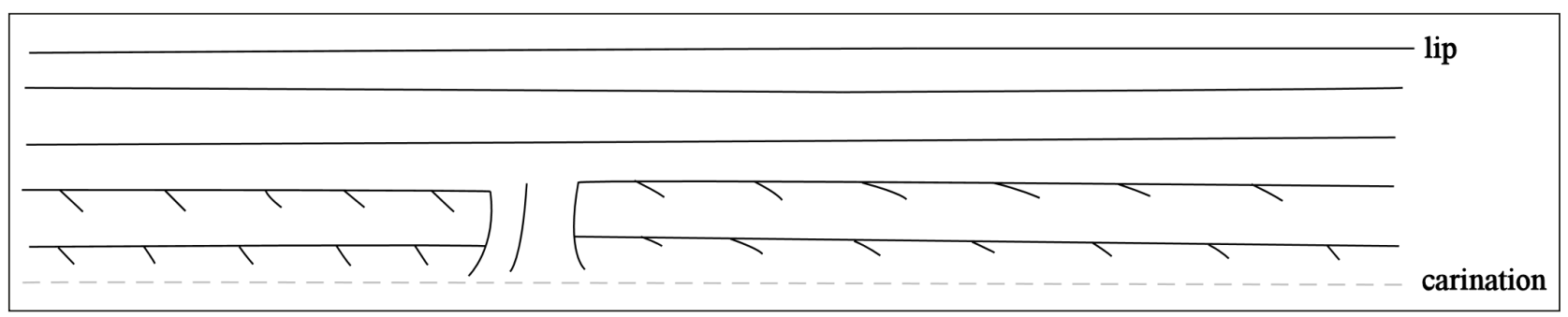

Figure 27. Decorative elements on Barkman Engraved carinated bowl (F.S. 1432) under Zone H in the platform mound at the Hatchel site. 
SITE NAME OR SITE NUMBER: Hatchel (41BW3)

VESSEL NO.: F.S. 1596, above Zone I in the platform mound

VESSEL FORM: Carinated bowl

NON-PLASTICS AND PASTE: grog

RIM AND LIP FORM: Inverted rim and rounded lip

CORE COLOR: $\mathrm{G}$ (fired in a reducing environment and cooled in the open air)

INTERIOR SURFACE COLOR: dark grayish-brown; fire clouds on the body; vessel appears to have been refired

EXTERIOR SURFACE COLOR: yellowish-brown; fire clouds on the rim, body, and base

WALL THICKNESS (IN MM): rim, $6.3 \mathrm{~mm}$; body, $6.4 \mathrm{~mm}$

INTERIOR SURFACE TREATMENT:

smoothed

EXTERIOR SURFACE TREATMENT: burnished

HEIGHT (IN CM): 10.8

ORIFICE DIAMETER (IN CM): 15.4

DIAMETER AT BOTTOM OF RIM OR NECK (IN CM): 15.9

BASE DIAMETER (IN CM) AND SHAPE OF BASE: $5.7 \mathrm{~cm}$; circular and rounded

ESTIMATED VOLUME (IN LITERS): 1.0

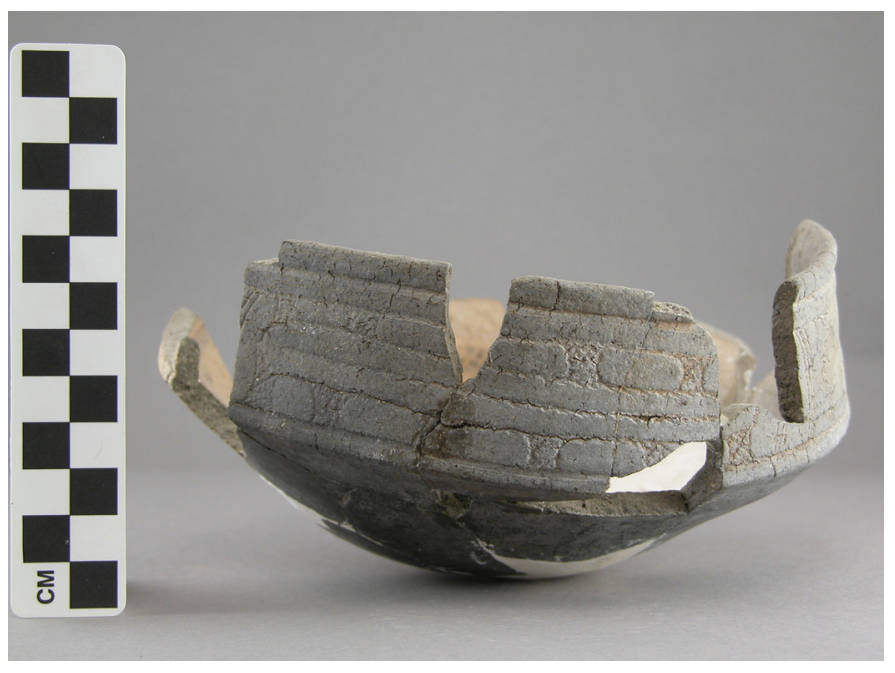

Figure 28. Barkman Engraved carinated bowl section (F.S. 1596), above Zone $I$ in the platform mound at the Hatchel site.

DECORATION (INCLUDING MOTIF AND ELEMENTS WHEN APPARENT): The upper part of the rim has two horizontal engraved lines. The remainder of the rim panel has a repeating set of four ovalshaped zones connected to horizontal engraved lines above and below it by cross-hatched engraved brackets (Figure 28). The oval-shaped zones have a single central horizontal engraved lines with downward-pointing excised tick marks. The oval-shaped zones are separated from each other by sets of three closely-spaced curvilinear engraved lines.

PIGMENT USE AND LOCATION ON VESSEL: none

TYPE AND VARIETY (IF KNOWN): Barkman Engraved 
SITE NAME OR SITE NUMBER: Hatchel (41BW3)

VESSEL NO.: 6-3-206; Zone $\mathrm{K}$ in the platform mound

VESSEL FORM: Carinated bowl

NON-PLASTICS AND PASTE: grog

RIM AND LIP FORM: Direct rim and rounded $\operatorname{lip}$

CORE COLOR: A (fired and cooled in an oxidizing environment)

INTERIOR SURFACE COLOR: yellowishbrown; fire clouds on the body

EXTERIOR SURFACE COLOR: yellowishbrown; fire clouds on the rim

WALL THICKNESS (IN MM): rim, $6.7 \mathrm{~mm}$

INTERIOR SURFACE TREATMENT: smoothed

EXTERIOR SURFACE TREATMENT:

smoothed on the body

HEIGHT (IN CM): 8.2

ORIFICE DIAMETER (IN CM): 15.7

DIAMETER AT BOTTOM OF RIM OR NECK (IN CM): 15.7

BASE DIAMETER (IN CM) AND SHAPE OF BASE: $8.9 \mathrm{~cm}$; circular and flat

ESTIMATED VOLUME (IN LITERS): 0.77

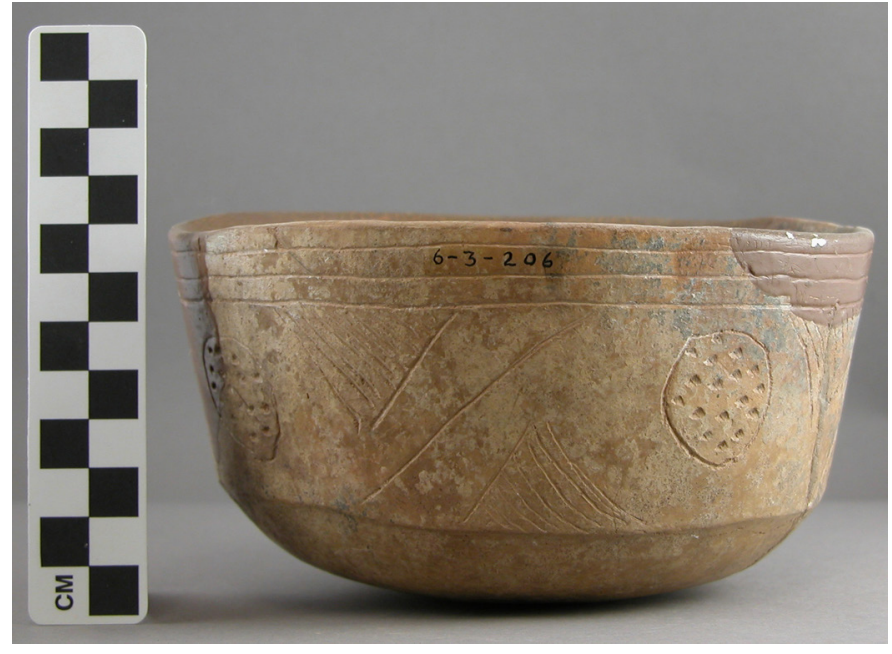

a

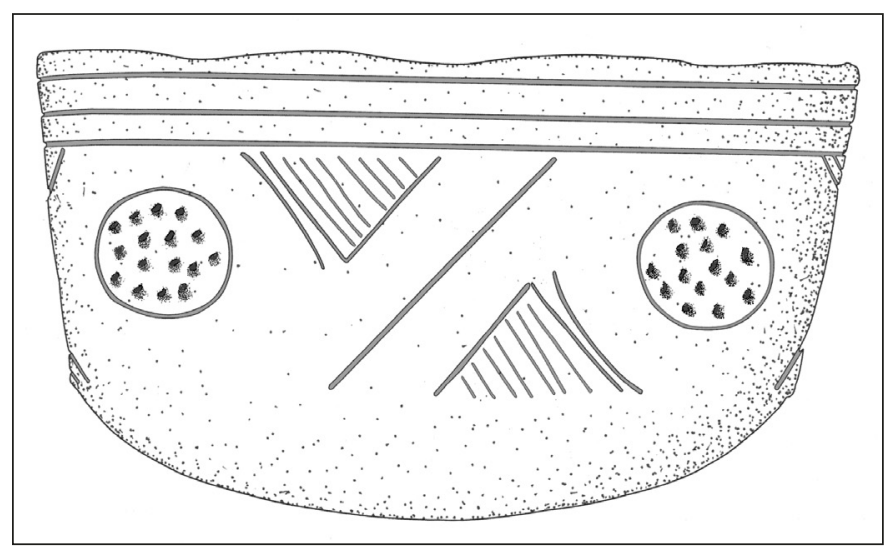

b

Figure 29. Crockett Curvilinear Incised (6-3-206) carinated bowl in Zone $K$ in the platform mound at the Hatchel site: a, photograph, courtesy of TARL; b, drawing, redrawn from Laughlin (1940).

DECORATION (INCLUDING MOTIF AND ELEMENTS WHEN APPARENT): The rim is decorated with three horizontal incised lines as well as slanting incised lines (slanting scroll line) around an incised circle motif repeated four times around the vessel (Figure 29a-b). The incised circle element is filled with rows of tool punctations. Above and below the slanting scroll lines are pendant triangle elements filled with diagonal and curvilinear incised lines.

PIGMENT USE AND LOCATION ON VESSEL: none

TYPE AND VARIETY (IF KNOWN): Crockett Curvilinear Incised 
SITE NAME OR SITE NUMBER: Hatchel (41BW3)

VESSEL NO.: 6-3-203; Burial 4 in a pit intruded into the side of the platform mound (Perttula 2014a:41)

VESSEL FORM: Jar

NON-PLASTICS AND PASTE: grog and bone

RIM AND LIP FORM: Everted rim and rounded $\operatorname{lip}$

CORE COLOR: F (fired in a reducing environment and cooled in the open air)

INTERIOR SURFACE COLOR: dark yellowishbrown; fire clouds on the body and base

EXTERIOR SURFACE COLOR: dark yellowishbrown; fire clouds on the base

WALL THICKNESS (IN MM): rim, $5.6 \mathrm{~mm}$

INTERIOR SURFACE TREATMENT: none

EXTERIOR SURFACE TREATMENT: none

HEIGHT (IN CM): 5.9

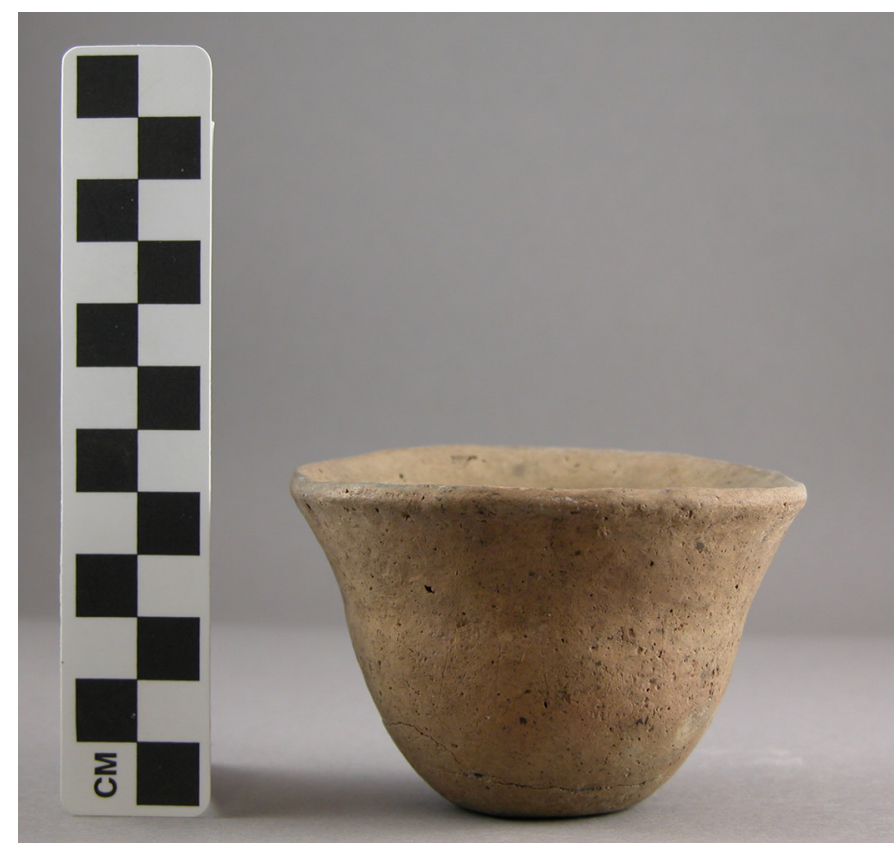

Figure 30. Plain jar (6-3-203) in Burial 4 in the platform mound at the Hatchel site. Photograph courtesy of TARL.

ORIFICE DIAMETER (IN CM): 8.2

DIAMETER AT BOTTOM OF RIM OR NECK (IN CM): 6.7

BASE DIAMETER (IN CM) AND SHAPE OF BASE: $3.1 \mathrm{~cm}$; circular and flat

ESTIMATED VOLUME (IN LITERS): 0.29

DECORATION (INCLUDING MOTIF AND ELEMENTS WHEN APPARENT): Plain (Figures 30 and 31c)

PIGMENT USE AND LOCATION ON VESSEL: none

TYPE AND VARIETY (IF KNOWN): Unidentified plain ware 


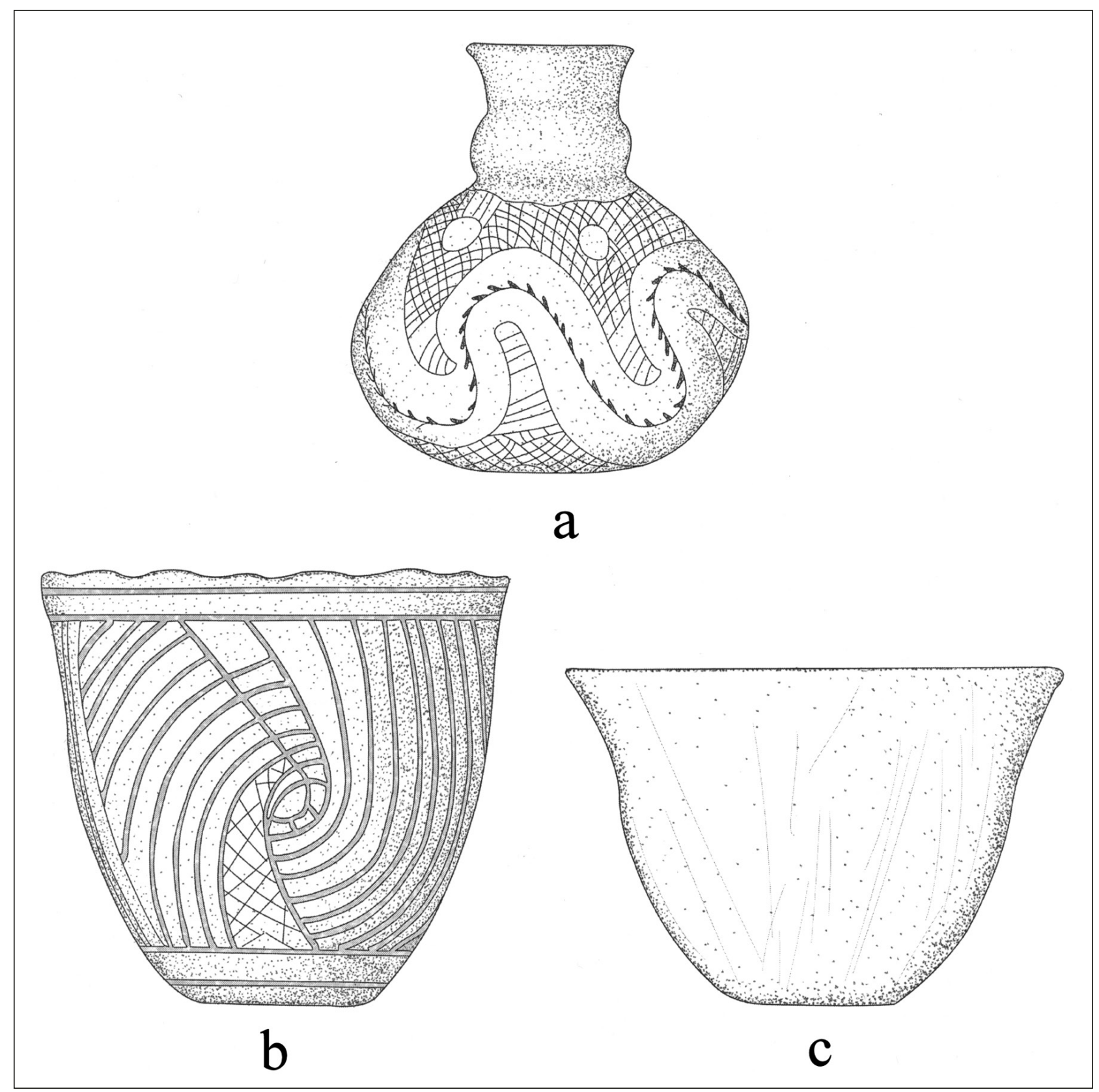

Figure 31. Drawings of vessels from Burial 4 in the platform mound at the Hatchel site: a, Hodges Engraved, var. Candler bottle; b, engraved bowl; c, plain jar. 
SITE NAME OR SITE NUMBER: Hatchel (41BW3)

VESSEL NO.: 6-3-204; Burial 4 in the platform mound

VESSEL FORM: Bottle with a spool neck

NON-PLASTICS AND PASTE: grog

RIM AND LIP FORM: Everted rim and rounded lip

CORE COLOR: B (fired and cooled in a reducing environment)

INTERIOR SURFACE COLOR: very dark grayish-brown

EXTERIOR SURFACE COLOR: very dark grayish-brown; fire clouds on the rim and body

WALL THICKNESS (IN MM): rim, 4.0 mm

INTERIOR SURFACE TREATMENT: none

EXTERIOR SURFACE TREATMENT: burnished

HEIGHT (IN CM): 7.6

ORIFICE DIAMETER (IN CM): 2.5

DIAMETER AT BOTTOM OF RIM OR NECK (IN CM): 2.6; maximum body diameter is 6.4 $\mathrm{cm}$

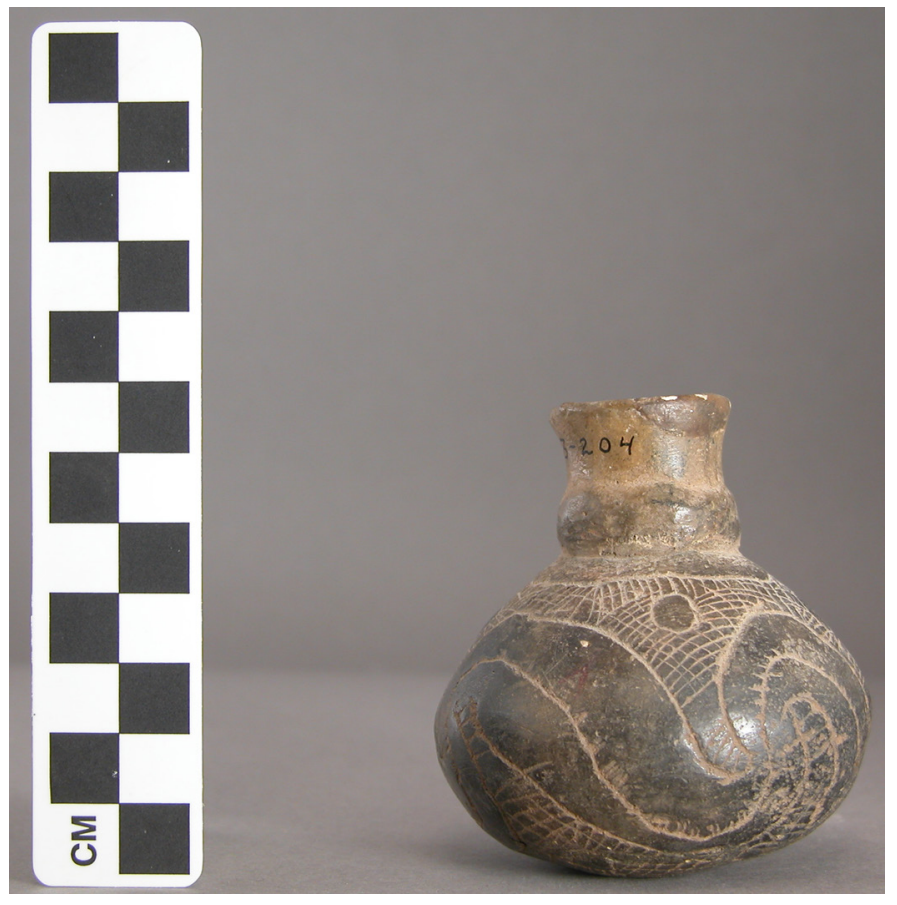

Figure 32. Hodges Engraved, var. Candler bottle in Burial 4 in the platform mound at the Hatchel site. Photograph courtesy of TARL.

BASE DIAMETER (IN CM) AND SHAPE OF BASE: $2.6 \mathrm{~cm}$; circular and flat

ESTIMATED VOLUME (IN LITERS): 0.1

DECORATION (INCLUDING MOTIF AND ELEMENTS WHEN APPARENT): The vessel body has an engraved meandering scroll with outward-pointing excised tick marks (Figure 32; see also Figure 31a). Above and below the meandering scroll lines are curvilinear cross-hatched engraved zones with hatched tips (nearest the scroll line). Below the tips of each of the cross-hatched and hatched zones are single negative circle elements (Figure 32).

PIGMENT USE AND LOCATION ON VESSEL: none

TYPE AND VARIETY (IF KNOWN): Hodges Engraved, var. Candler (Schambach and Miller 1984:122) 
SITE NAME OR SITE NUMBER: Hatchel (41BW3)

VESSEL NO.: 6-3-205; Burial 4 in the platform mound

VESSEL FORM: Bowl

NON-PLASTICS AND PASTE: grog and bone

RIM AND LIP FORM: Direct rim and rounded lip

CORE COLOR: B (fired and cooled in a reducing environment)

INTERIOR SURFACE COLOR: very dark grayish-brown; fire clouds on the rim

EXTERIOR SURFACE COLOR: very dark grayish-brown; fire clouds on the rim

WALL THICKNESS (IN MM): rim, $6.4 \mathrm{~mm}$

INTERIOR SURFACE TREATMENT: smoothed

EXTERIOR SURFACE TREATMENT:

smoothed

HEIGHT (IN CM): 7.2

ORIFICE DIAMETER (IN CM): 7.6

DIAMETER AT BOTTOM OF RIM OR NECK (IN CM): N/A

BASE DIAMETER (IN CM) AND SHAPE OF

BASE: $3.1 \mathrm{~cm}$; circular and flat

ESTIMATED VOLUME (IN LITERS): 0.22

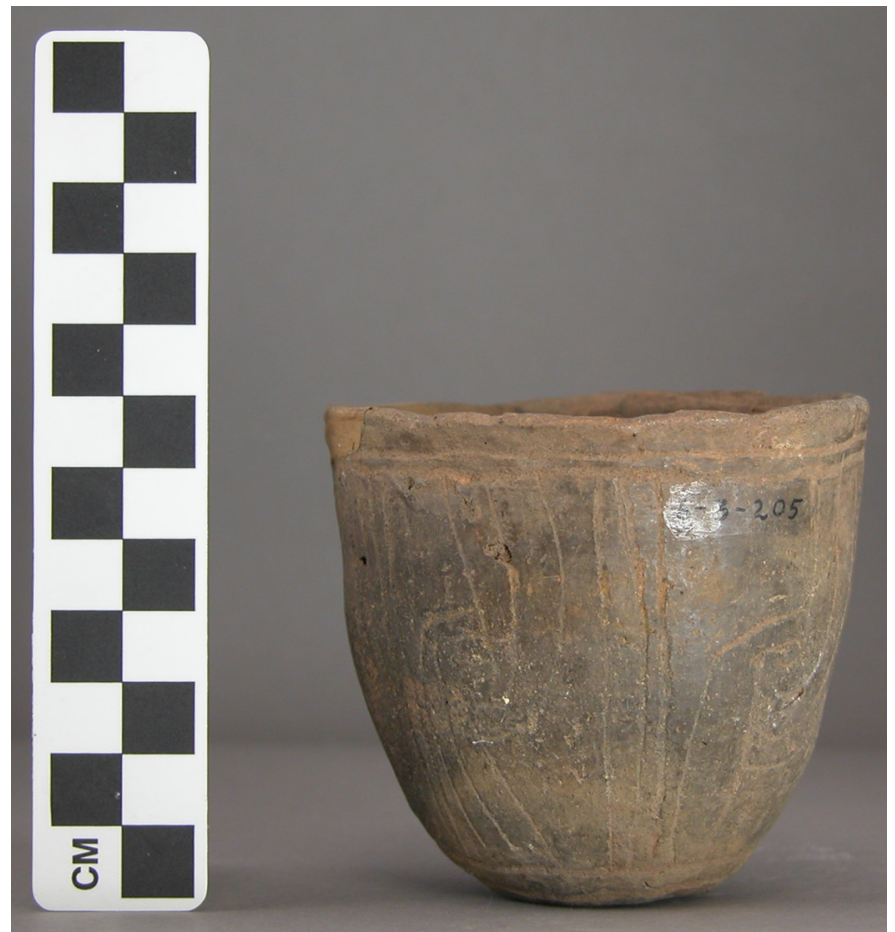

Figure 33. Engraved bowl (6-3-205) in Burial 4 in the platform mound at the Hatchel site. Photograph courtesy of TARL.

DECORATION (INCLUDING MOTIF AND ELEMENTS WHEN APPARENT): The vessel has two horizontal engraved lines at the top of the vessel and two near the vessel base. The panel between has four sets of vertical scrolls divided by sets of three vertical engraved lines (Figure 33; see also Figure 31b). Two sets of vertical scrolls have a central circle with a hooked arm as well as sets of curvilinear lines on either side of the scroll line. The other two sets have a narrow scroll zone filled with hatched lines, and there are sets of curvilinear engraved lines on either side of the scroll zone (Figure 33).

PIGMENT USE AND LOCATION ON VESSEL: none

TYPE AND VARIETY (IF KNOWN): Unidentified fine ware 
SITE NAME OR SITE NUMBER: Hatchel (41BW3)

VESSEL NO.: F.S. 1648, Square 25R 22 in the platform mound

VESSEL FORM: Jar with a short rim

NON-PLASTICS AND PASTE: grog

RIM AND LIP FORM: Everted rim and rounded lip

CORE COLOR: B (fired and cooled in a reducing environment)

INTERIOR SURFACE COLOR: black

EXTERIOR SURFACE COLOR: black

WALL THICKNESS (IN MM): rim, $4.2 \mathrm{~mm}$

INTERIOR SURFACE TREATMENT: burnished

EXTERIOR SURFACE TREATMENT: burnished

HEIGHT (IN CM): 9.0

ORIFICE DIAMETER (IN CM): 7.8

DIAMETER AT BOTTOM OF RIM OR NECK (IN CM): 7.6

BASE DIAMETER (IN CM) AND SHAPE OF BASE: $5.1 \mathrm{~cm}$; circular and rounded

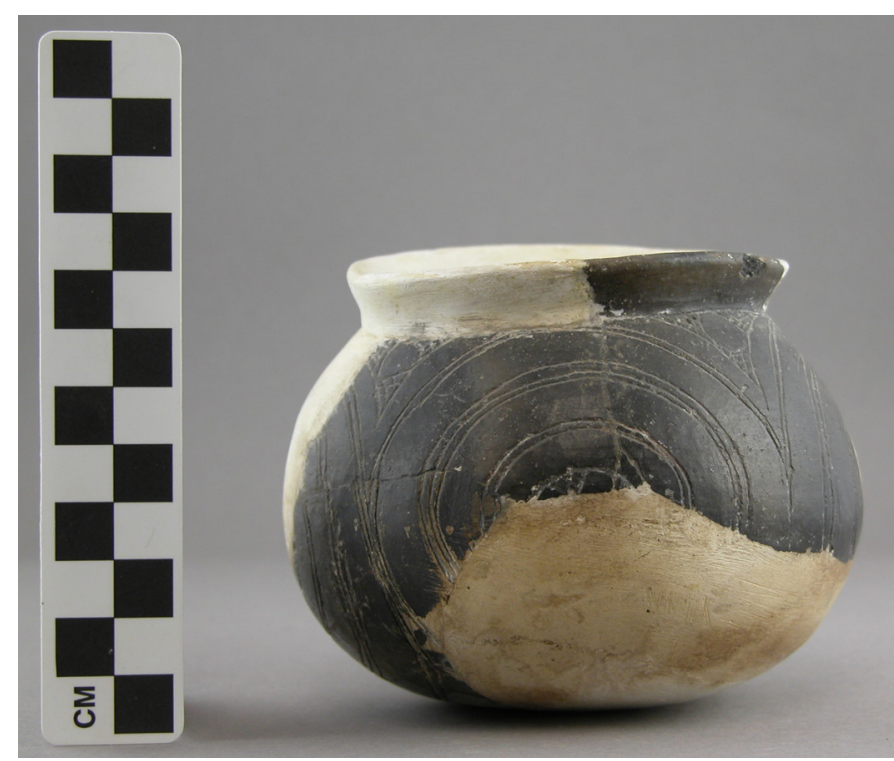

Figure 34. cf. Belcher Engraved, var. Ogden jar (F.S. 1648) in the platform mound at the Hatchel site. Photograph courtesy of TARL.

\section{ESTIMATED VOLUME (IN LITERS): 0.42}

DECORATION (INCLUDING MOTIF AND ELEMENTS WHEN APPARENT): The vessel body has a concentric circle motif repeated four times around the vessel. The motif is comprised of several series of closely-spaced concentric lines around a central circle with an unidentified central element (Figure 34). The concentric circles are divided by a series of four engraved triangle elements with negative inner circles outlined by cross-hatched zones.

PIGMENT USE AND LOCATION ON VESSEL: none

TYPE AND VARIETY (IF KNOWN): cf. Belcher Engraved, var. Ogden (Schambach and Miller 1984:120) 


\section{Vessels from Burial Plot Features}

A number of ancestral Caddo burial features were excavated during the WPA investigations at the Hatchel site. These burial plots were situated east and southeast of the platform mound (see Figures $1 \mathrm{~b}$ and 5a), along the edge of the alluvial landform and mainly north of Village Area V.

SITE NAME OR SITE NUMBER: Hatchel (41BW3)

VESSEL NO.: 6-1-1; Burial Plot 1, Burial 1

VESSEL FORM: Jar

NON-PLASTICS AND PASTE: grog

RIM AND LIP FORM: Everted rim and rounded lip

CORE COLOR: $\mathrm{G}$ (fired in a reducing environment and cooled in the open air)

INTERIOR SURFACE COLOR: very dark grayish-brown

EXTERIOR SURFACE COLOR: dark reddishbrown; fire clouds on the rim, body, and base

WALL THICKNESS (IN MM): rim, $5.9 \mathrm{~mm}$

INTERIOR SURFACE TREATMENT: smoothed

EXTERIOR SURFACE TREATMENT: none

HEIGHT (IN CM): 18.8

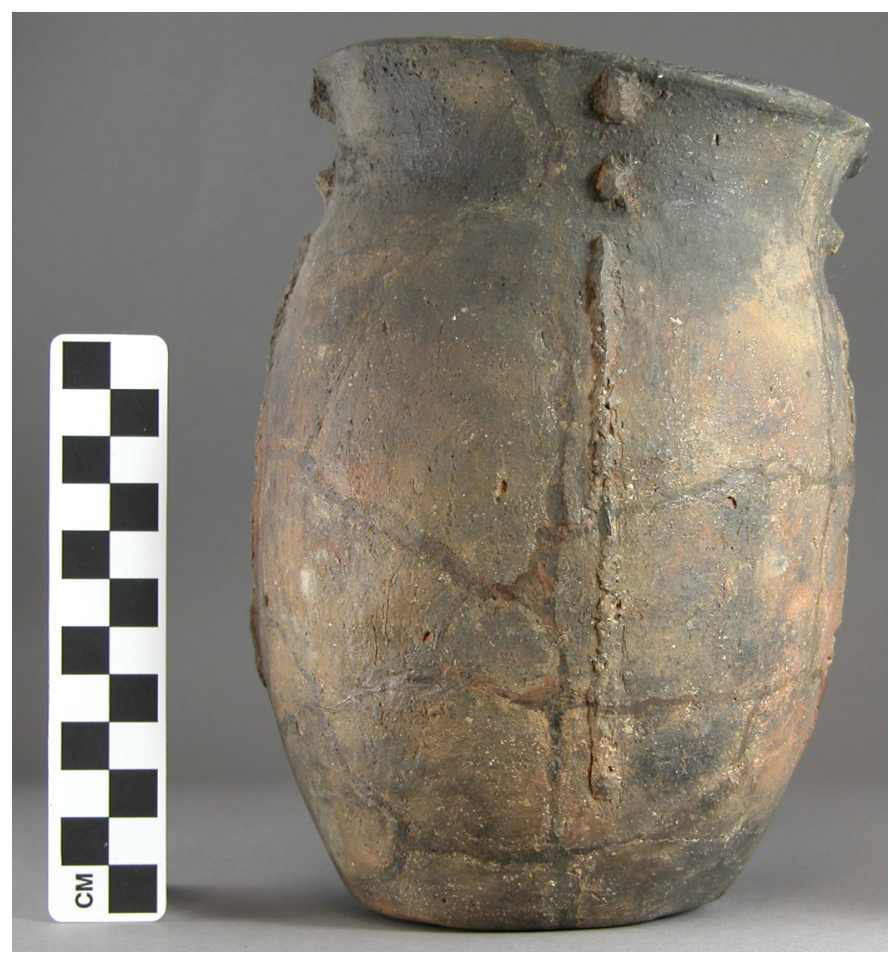

Figure 35. McKinney Plain jar (6-1-1) in Burial 1 in Burial Plot 1 at the Hatchel site. Photograph courtesy

ORIFICE DIAMETER (IN CM): 12.1 of TARL.

DIAMETER AT BOTTOM OF RIM OR NECK (IN CM): 11.4

BASE DIAMETER (IN CM) AND SHAPE OF BASE: $7.2 \mathrm{~cm}$; circular and flat

ESTIMATED VOLUME (IN LITERS): 2.1

DECORATION (INCLUDING MOTIF AND ELEMENTS WHEN APPARENT): The rim has horizontal brushing marks as well as four vertical sets of appliqued nodes (Figure 35). The vessel body has four vertical appliqued ridges, placed under the appliqued nodes on the rim, that extend from the rim-body juncture to $3.7 \mathrm{~cm}$ above the vessel base.

PIGMENT USE AND LOCATION ON VESSEL: none

TYPE AND VARIETY (IF KNOWN): McKinney Plain 
SITE NAME OR SITE NUMBER: Hatchel (41BW3)

VESSEL NO.: 6-1-2; Burial Plot 1, Burial 1

VESSEL FORM: Bottle

NON-PLASTICS AND PASTE: grog

RIM AND LIP FORM: Everted rim and rounded lip

CORE COLOR: $\mathrm{H}$ (fired in a reducing environment and cooled in the open air)

INTERIOR SURFACE COLOR: yellowishbrown

EXTERIOR SURFACE COLOR: black; fire clouds on the rim and body

WALL THICKNESS (IN MM): rim, $4.8 \mathrm{~mm}$

INTERIOR SURFACE TREATMENT: none

EXTERIOR SURFACE TREATMENT: burnished

HEIGHT (IN CM): 13.3

ORIFICE DIAMETER (IN CM): 3.7

DIAMETER AT BOTTOM OF RIM OR NECK

(IN CM): 3.9 ; maximum body diameter of $8.2 \mathrm{~cm}$

BASE DIAMETER (IN CM) AND SHAPE OF

BASE: $5.0 \mathrm{~cm}$; circular and rounded

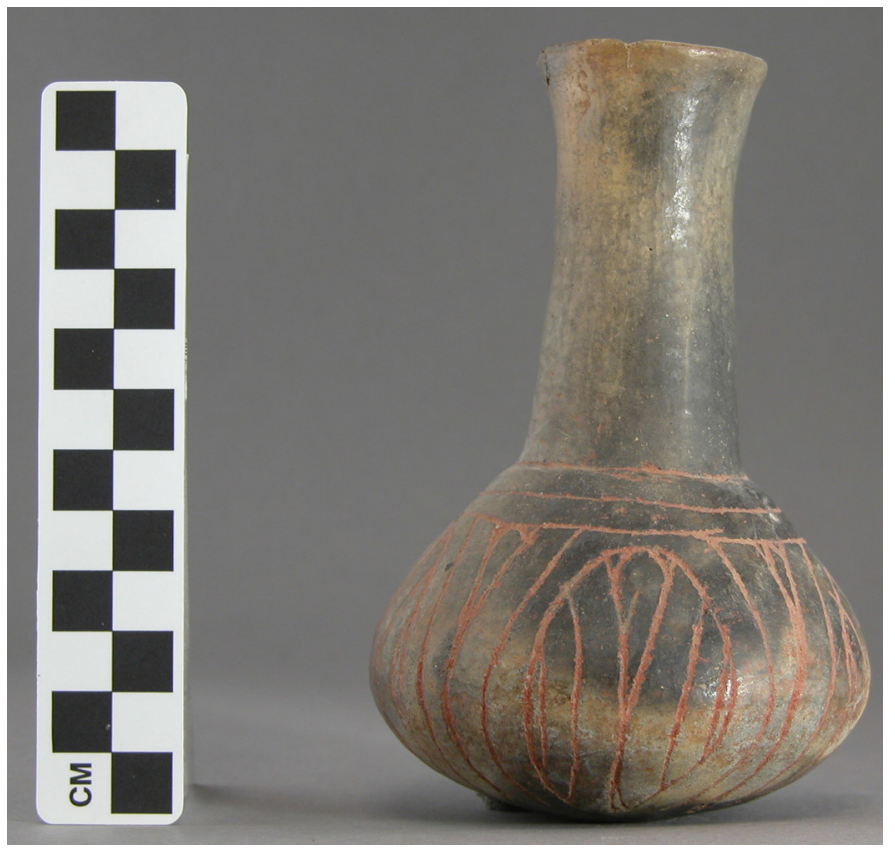

Figure 36. Hatchel Engraved bottle (6-1-2) in Burial 1 in Burial Plot 1 at the Hatchel site. Photograph courtesy of TARL.

\section{ESTIMATED VOLUME (IN LITERS): 0.27}

DECORATION (INCLUDING MOTIF AND ELEMENTS WHEN APPARENT): There are three horizontal engraved lines at the top of the vessel panel and a body panel with four sets of an engraved motif. The motif consists of a large semi-circle filled with vertical engraved lines; one vertical line is bifurcated near the top of the semi-circle (Figure 36). The motifs are divided by a single vertical engraved line that merges with an engraved pendant triangle; the pendant triangles have either diagonal opposed lines or excised opposed zones (Figure 36).

PIGMENT USE AND LOCATION ON VESSEL: red pigment in the engraved lines

TYPE AND VARIETY (IF KNOWN): Hatchel Engraved 
SITE NAME OR SITE NUMBER: Hatchel (41BW3)

VESSEL NO.: 6-1-3; Burial Plot 1, Burial 2

VESSEL FORM: Bottle with a pedestal base (Figure 37)

NON-PLASTICS AND PASTE: shell

RIM AND LIP FORM: Everted rim and rounded lip

CORE COLOR: $\mathrm{H}$ (fired in a reducing environment and cooled in the open air)

INTERIOR SURFACE COLOR: reddish-brown

EXTERIOR SURFACE COLOR: grayish-brown; fire clouds on the rim and body

WALL THICKNESS (IN MM): rim, 5.4 mm

INTERIOR SURFACE TREATMENT: none

EXTERIOR SURFACE TREATMENT: none

HEIGHT (IN CM): 18.3

ORIFICE DIAMETER (IN CM): 5.8

DIAMETER AT BOTTOM OF RIM OR NECK

(IN CM): 6.5 ; maximum body diameter is 17.2 $\mathrm{cm}$

BASE DIAMETER (IN CM) AND SHAPE OF BASE: $7.0 \mathrm{~cm}$; circular and concave; the pedestal base is $2.8 \mathrm{~cm}$ in height (Figure 37)

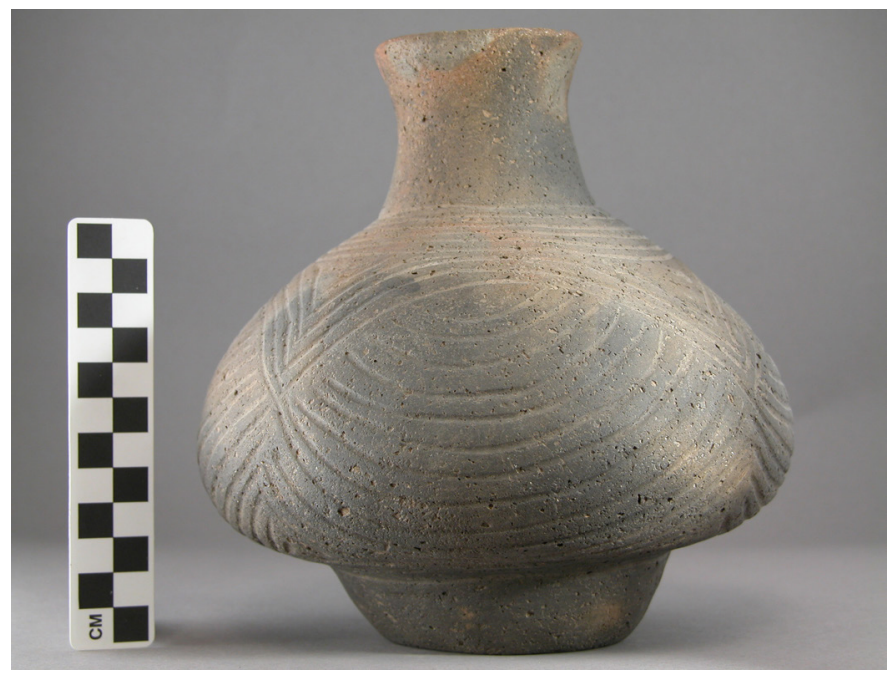

Figure 37. Keno Trailed, var. Glendora bottle (6-1-3) in Burial 2 in Burial Plot 2 at the Hatchel site.

\section{ESTIMATED VOLUME (IN LITERS): 0.51}

DECORATION (INCLUDING MOTIF AND ELEMENTS WHEN APPARENT): The upper body has six horizontal trailed lines while the lower body has three horizontal trailed lines (Figure 37). The panel between has four sets of semi-circles filled with concentric semi-circular trailed lines. Each of the sets of concentric semi-circular lines is divided by sets of upward- or lower-pointing triangular trailed lines (Figure 37).

PIGMENT USE AND LOCATION ON VESSEL: none

TYPE AND VARIETY (IF KNOWN): Keno Trailed, var. Glendora (see Schambach and Miller 1984:123) 
SITE NAME OR SITE NUMBER: Hatchel (41BW3)

VESSEL NO.: 6-1-4; Burial Plot 1, Burial 10

VESSEL FORM: Bowl with scalloped and flattened lip (Figure 38)

NON-PLASTICS AND PASTE: grog

RIM AND LIP FORM: Direct rim and flattened lip

CORE COLOR: $\mathrm{G}$ (fired in a reducing environment and cooled in the open air)

INTERIOR SURFACE COLOR: very dark grayish-brown; fire clouds on the rim

EXTERIOR SURFACE COLOR: reddish-brown

WALL THICKNESS (IN MM): rim, $5.1 \mathrm{~mm}$

INTERIOR SURFACE TREAT-

MENT: smoothed

EXTERIOR SURFACE TREAT-

MENT: smoothed

HEIGHT (IN CM): 3.2

ORIFICE DIAMETER (IN CM): 8.3

DIAMETER AT BOTTOM OF RIM

OR NECK (IN CM): N/A

BASE DIAMETER (IN CM) AND

SHAPE OF BASE: $3.7 \mathrm{~cm}$; circular and rounded

ESTIMATED VOLUME (IN LI-

TERS): 0.1

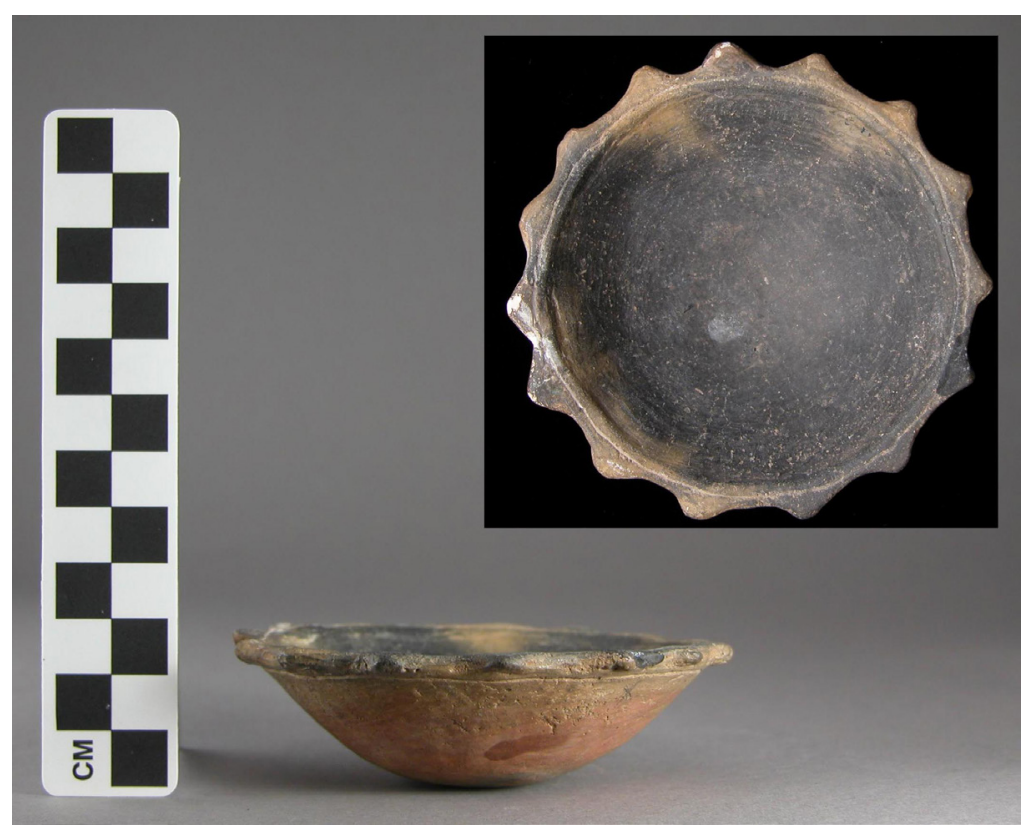

Figure 38. Side and top views of an engraved bowl (61-4) from Burial 10 in Burial Plot 1 at the Hatchel site. Photograph courtesy of TARL.

DECORATION (INCLUDING MOTIF AND ELEMENTS WHEN APPARENT): There is a single horizontal engraved line under the vessel lip, as well as a single horizontal engraved line on the flattened lip (Figure 38).

PIGMENT USE AND LOCATION ON VESSEL: none

TYPE AND VARIETY (IF KNOWN): Unidentified fine ware 
SITE NAME OR SITE NUMBER: Hatchel (41BW3)

VESSEL NO.: 6-1-5; Burial Plot 1

VESSEL FORM: Jar

NON-PLASTICS AND PASTE: grog and bone

RIM AND LIP FORM: Everted rim and rounded lip

CORE COLOR: $\mathrm{G}$ (fired in a reducing environment and cooled in the open air)

INTERIOR SURFACE COLOR: very dark grayish-brown; fire clouds on the body and base

EXTERIOR SURFACE COLOR: dark yellowishbrown; fire clouds on the rim, body, and base

WALL THICKNESS (IN MM): rim, $4.6 \mathrm{~mm}$

INTERIOR SURFACE TREATMENT: none

EXTERIOR SURFACE TREATMENT: none

HEIGHT (IN CM): 8.9

ORIFICE DIAMETER (IN CM): 10.8

DIAMETER AT BOTTOM OF RIM OR NECK (IN CM): 8.6

BASE DIAMETER (IN CM) AND SHAPE OF BASE: $8.3 \mathrm{~cm}$; circular and flat

ESTIMATED VOLUME (IN LITERS): 0.57

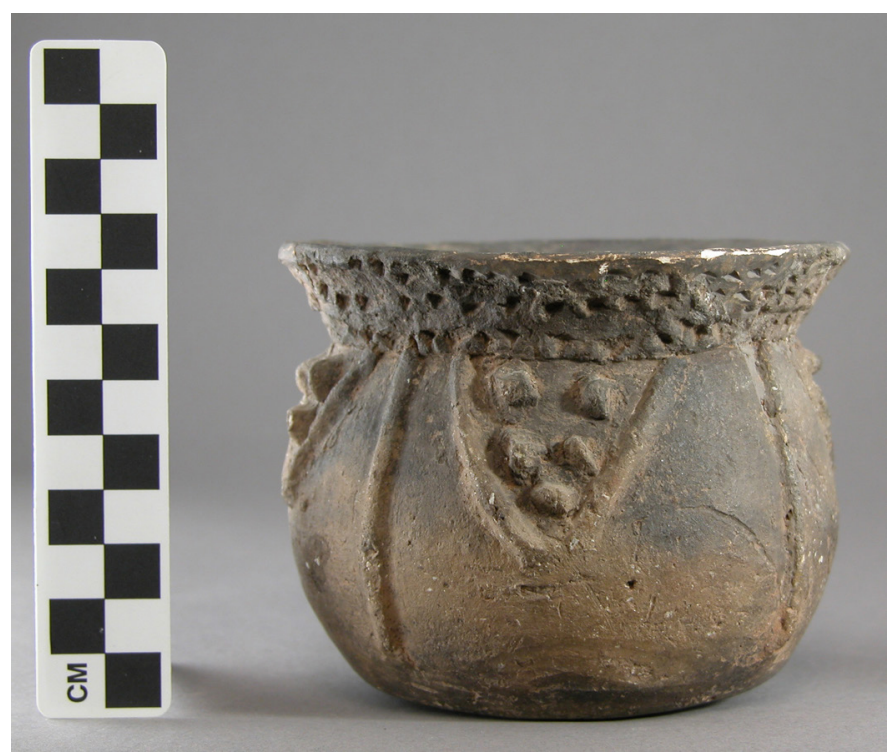

Figure 39. Punctated-appliqued jar (6-1-5) from Burial Plot 1 at the Hatchel site. Photograph courtesy of TARL.

DECORATION (INCLUDING MOTIF AND ELEMENTS WHEN APPARENT): The rim of the vessel is decorated with three horizontal rows of large triangular-shaped tool punctations (Figure 39). The vessel body is divided into four panels by vertical appliqued ridges that extend from the rim-body juncture to just above the base. Within each of the panels are a single semi-circular appliqued ridge filled with either three (two panels), four (one panel), or five (one panel) large appliqued nodes (Figure 39).

PIGMENT USE AND LOCATION ON VESSEL: none

TYPE AND VARIETY (IF KNOWN): Unidentified utility ware 
SITE NAME OR SITE NUMBER: Hatchel (41BW3)

VESSEL NO.: 6-1-6; Burial Plot 1

VESSEL FORM: Jar

NON-PLASTICS AND PASTE: grog

RIM AND LIP FORM: Everted rim and rounded lip

CORE COLOR: $\mathrm{G}$ (fired in a reducing environment and cooled in the open air)

INTERIOR SURFACE COLOR: very dark grayish-brown; fire clouds on the body and base

EXTERIOR SURFACE COLOR: dark yellowishbrown; fire clouds on the rim and body

WALL THICKNESS (IN MM): rim, $5.2 \mathrm{~mm}$

INTERIOR SURFACE TREATMENT: smoothed

EXTERIOR SURFACE TREATMENT: smoothed on the rim; burnished on the body

HEIGHT (IN CM): 10.8

ORIFICE DIAMETER (IN CM): 10.8

DIAMETER AT BOTTOM OF RIM OR NECK (IN CM): 10.3

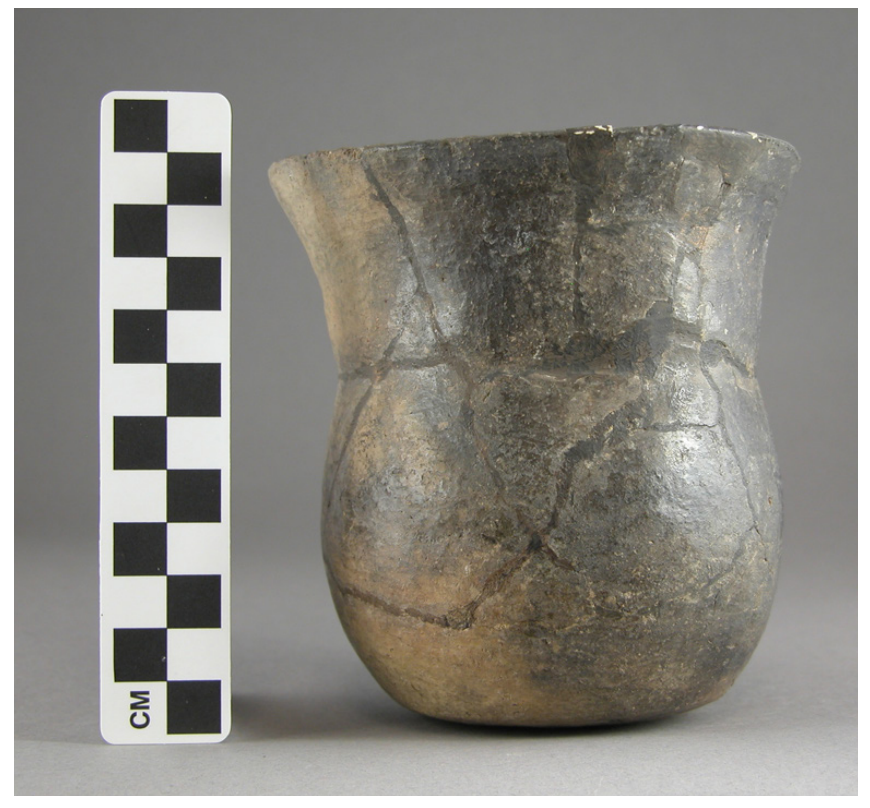

BASE DIAMETER (IN CM) AND SHAPE OF BASE: 6.4 ; circular and flat

ESTIMATED VOLUME (IN LITERS): 7.1

DECORATION (INCLUDING MOTIF AND ELEMENTS WHEN APPARENT): Plain (Figure 40) PIGMENT USE AND LOCATION ON VESSEL: none TYPE AND VARIETY (IF KNOWN): Unidentified plain ware
Figure 40. Plain jar (6-1-6) from Burial Plot 1 at the Hatchel site. Photograph courtesy of TARL. 
SITE NAME OR SITE NUMBER: Hatchel (41BW3)

VESSEL NO.: 6-1-7; Burial Plot 1, Burial 14

VESSEL FORM: Bottle

NON-PLASTICS AND PASTE: grog

RIM AND LIP FORM: Direct rim and rounded lip

CORE COLOR: F (fired in a reducing environment and cooled in the open air)

INTERIOR SURFACE COLOR: brown

EXTERIOR SURFACE COLOR: brown

WALL THICKNESS (IN MM): rim, $5.3 \mathrm{~mm}$

INTERIOR SURFACE TREATMENT: none

EXTERIOR SURFACE TREATMENT:

smoothed

HEIGHT (IN CM): 17.1

ORIFICE DIAMETER (IN CM): 3.1

DIAMETER AT BOTTOM OF RIM OR NECK (IN CM): 3.8 ; maximum body diameter is $8.3 \mathrm{~cm}$

BASE DIAMETER (IN CM) AND SHAPE OF BASE: $5.1 \mathrm{~cm}$; circular and flat

ESTIMATED VOLUME (IN LITERS): 0.35

DECORATION (INCLUDING MOTIF AND ELEMENTS WHEN APPARENT): The upper vessel body has three horizontal engraved lines (Figure 41).

PIGMENT USE AND LOCATION ON VESSEL: none

TYPE AND VARIETY (IF KNOWN): Unidentified fine ware, possibly Hickory Engraved

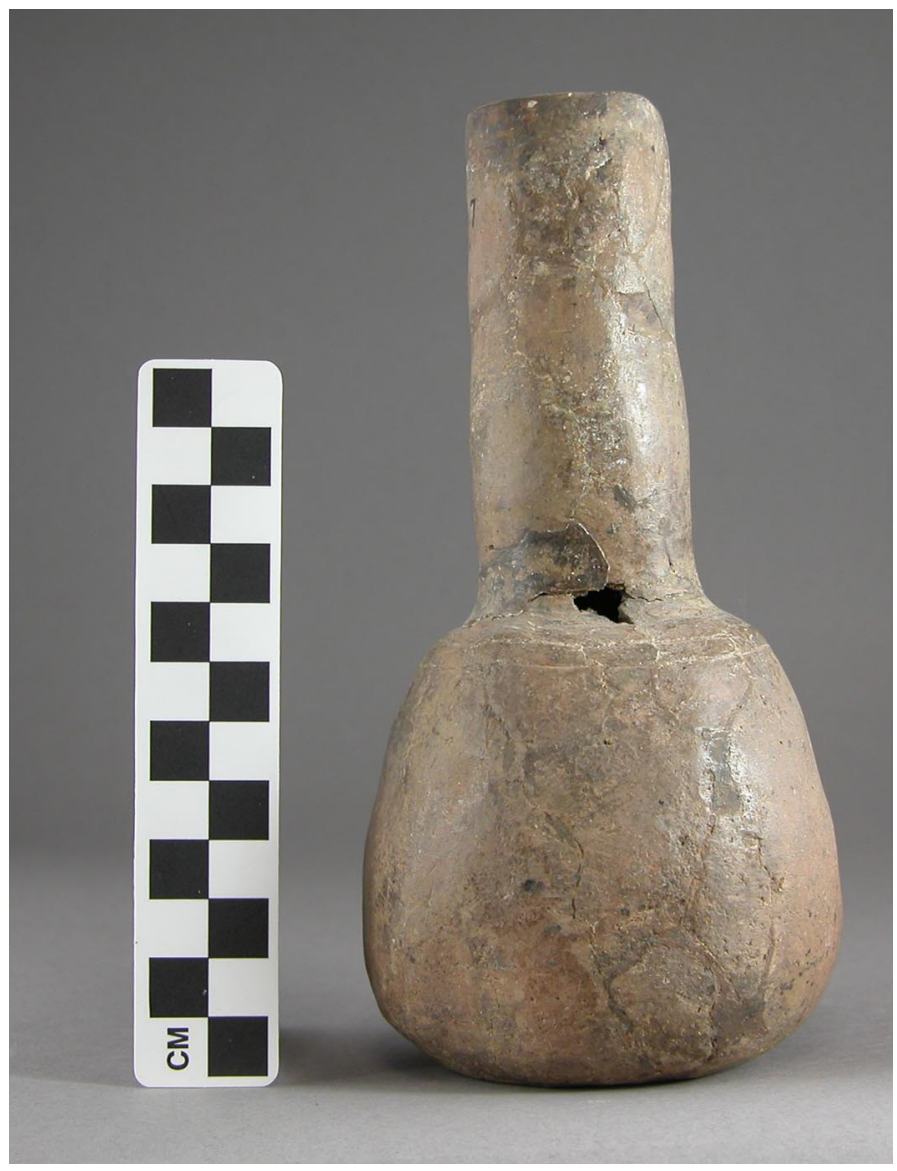

Figure 41. Engraved bottle (6-1-7) in Burial Plot 1, Burial 14 at the Hatchel site. Photograph courtesy of TARL. 
SITE NAME OR SITE NUMBER: Hatchel (41BW3)

VESSEL NO.: 6-1-8; Burial Plot 1, Burial 14

VESSEL FORM: Four-sided bowl with rim peaks (Figure 42)

NON-PLASTICS AND PASTE: grog

RIM AND LIP FORM: Direct rim and rounded lip

CORE COLOR: $\mathrm{G}$ (fired in a reducing environment and cooled in the open air)

INTERIOR SURFACE COLOR: dark reddishbrown; fire clouds on the rim and base

EXTERIOR SURFACE COLOR: dark reddishbrown; fire clouds on the rim and base

WALL THICKNESS (IN MM): rim, $5.7 \mathrm{~mm}$

INTERIOR SURFACE TREATMENT: smoothed

EXTERIOR SURFACE TREATMENT:

smoothed on the body

HEIGHT (IN CM): $4.3 ; 5.7 \mathrm{~cm}$ at the rim peaks

ORIFICE DIAMETER (IN CM): 13.4

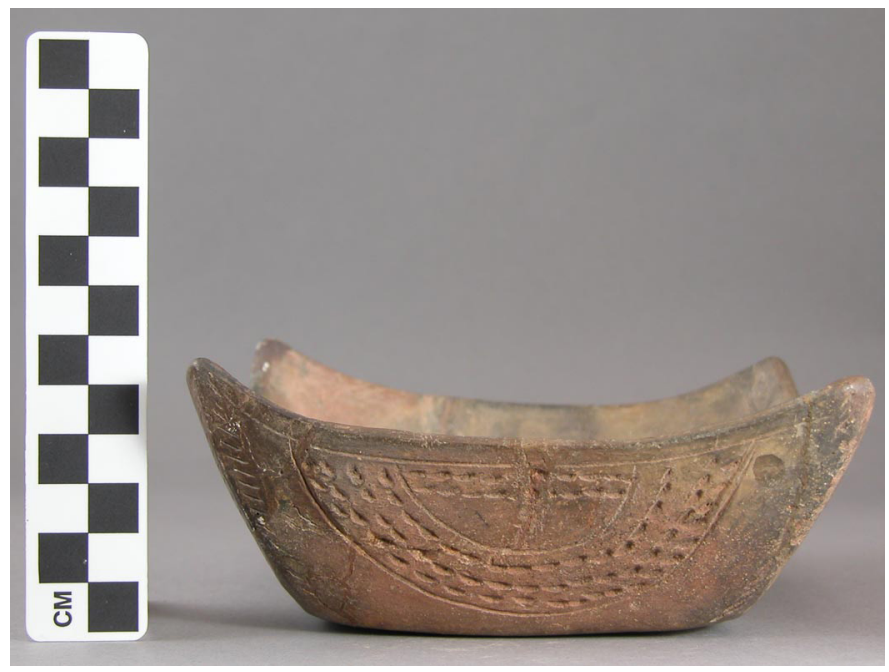

Figure 42. Crockett Curvilinear Incised four-sided bowl (6-1-8) in Burial 14 in Burial Plot 1 at the Hatchel site. Photograph courtesy of TARL.

DIAMETER AT BOTTOM OF RIM OR NECK (IN CM): N/A

BASE DIAMETER (IN CM) AND SHAPE OF BASE: $8.9 \mathrm{~cm}$; square and flat

ESTIMATED VOLUME (IN LITERS): 0.23

DECORATION (INCLUDING MOTIF AND ELEMENTS WHEN APPARENT): Each side of the bowl has semi-circular incised zones filled with rows of tool punctations (Figure 42). One side has three concentric semi-circles, one filled with three rows of punctations and the smallest semi-circle with one row of punctations; another side has two concentric semi-circles filled with two to three rows of punctations; the third side has two concentric semi-circles filled with either one or four rows of tool punctations; and the fourth side has two concentric semi-circles filled with either one or two rows of tool punctations.

PIGMENT USE AND LOCATION ON VESSEL: none

TYPE AND VARIETY (IF KNOWN): Crockett Curvilinear Incised 
SITE NAME OR SITE NUMBER: Hatchel (41BW3)

VESSEL NO.: 6-1-13; Burial Plot 1, back dirt

VESSEL FORM: Carinated bowl

NON-PLASTICS AND PASTE: grog

RIM AND LIP FORM: Inverted rim and rounded lip

CORE COLOR: B (fired and cooled in a reducing environment)

INTERIOR SURFACE COLOR: black

EXTERIOR SURFACE COLOR: black; fire clouds on the rim and body

WALL THICKNESS (IN MM): rim, 2.8 mm; body, $4.2 \mathrm{~mm}$

INTERIOR SURFACE TREATMENT: burnished

EXTERIOR SURFACE TREATMENT: burnished

HEIGHT (IN CM): 2.5

ORIFICE DIAMETER (IN CM): 7.0

DIAMETER AT BOTTOM OF RIM OR NECK (IN CM): 8.4

BASE DIAMETER (IN CM) AND SHAPE OF BASE: N/A

ESTIMATED VOLUME (IN LITERS): 0.1

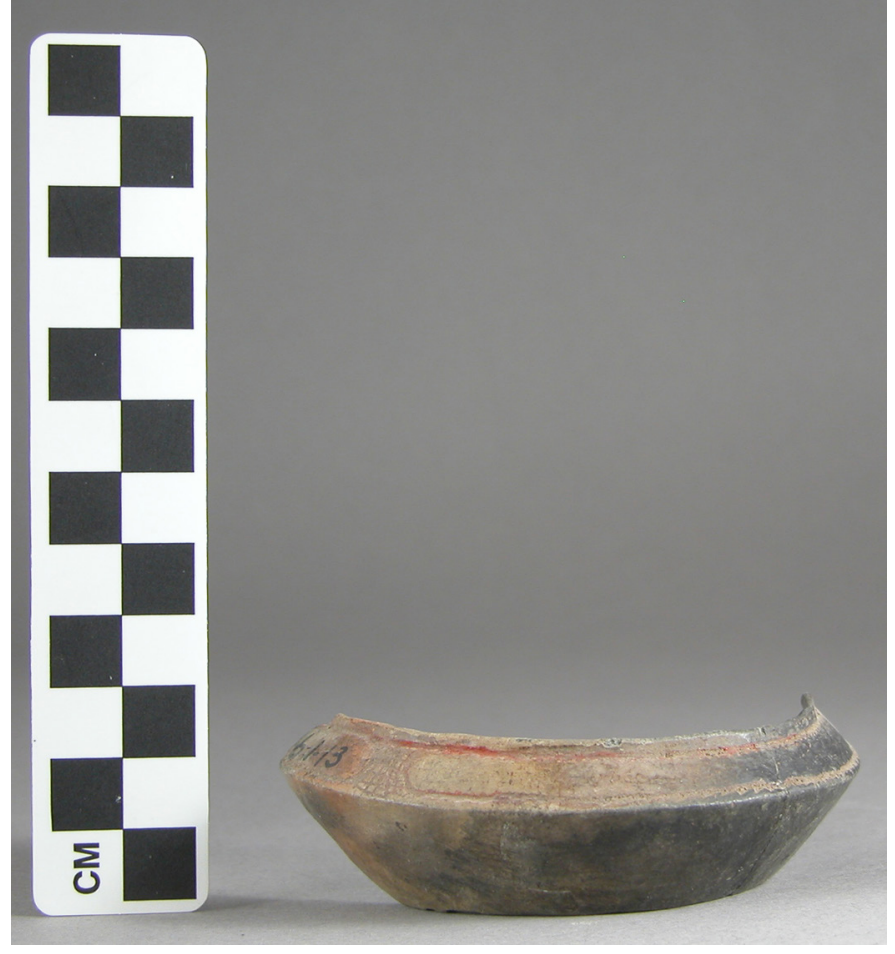

Figure 43. Simms Engraved carinated bowl (6-113) in Burial Plot 1 at the Hatchel site. Photograph courtesy of TARL.

DECORATION (INCLUDING MOTIF AND ELEMENTS WHEN APPARENT): The rim of the vessel is divided into panels (four, most likely) by cross-hatched engraved brackets (Figure 43). The top and bottom of the panels are marked by single horizontal engraved lines with downward-pointing excised tick marks.

PIGMENT USE AND LOCATION ON VESSEL: red pigment in the engraved lines

TYPE AND VARIETY (IF KNOWN): Simms Engraved 
SITE NAME OR SITE NUMBER: Hatchel (41BW3)

VESSEL NO.: 6-1-20; Burial Plot 2, Burial 20

VESSEL FORM: Carinated bowl

NON-PLASTICS AND PASTE: grog

RIM AND LIP FORM: Direct rim and rounded lip

CORE COLOR: B (fired and cooled in a reducing environment)

INTERIOR SURFACE COLOR: black; fire clouds on the base

EXTERIOR SURFACE COLOR: very dark grayish-brown; fire clouds on the body

WALL THICKNESS (IN MM): rim, $4.2 \mathrm{~mm}$

INTERIOR SURFACE TREATMENT: burnished on the rim; smoothed on the body and base

EXTERIOR SURFACE TREATMENT: burnished

HEIGHT (IN CM): 6.3

ORIFICE DIAMETER (IN CM): 15.9

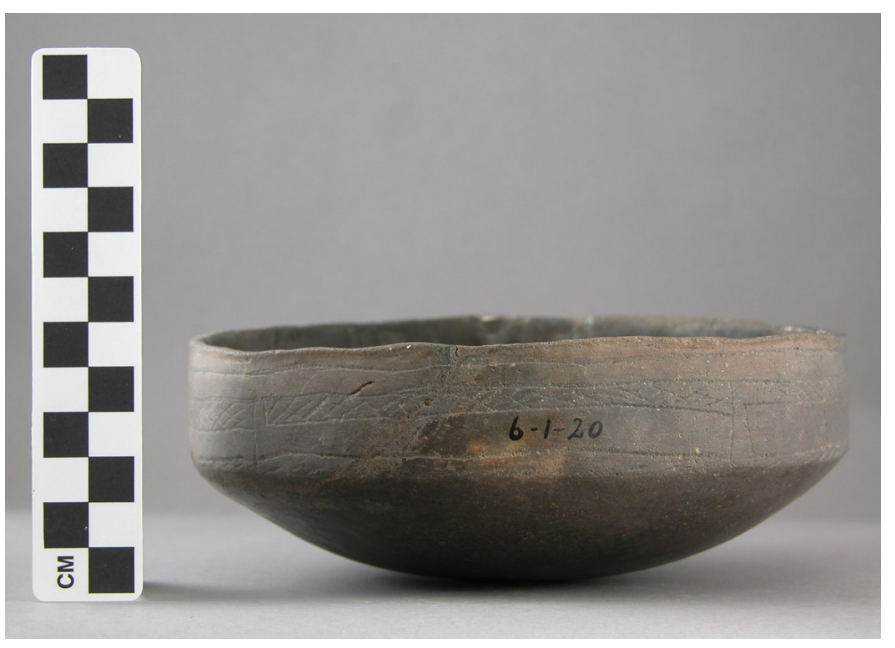

Figure 44. Barkman Engraved carinated bowl (6-120) in Burial 20 in Burial Plot 2 at the Hatchel site. Photograph courtesy of TARL.

DIAMETER AT BOTTOM OF RIM OR NECK (IN CM): 15.9

BASE DIAMETER (IN CM) AND SHAPE OF BASE: $8.2 \mathrm{~cm}$; circular and rounded

ESTIMATED VOLUME (IN LITERS): 0.6

DECORATION (INCLUDING MOTIF AND ELEMENTS WHEN APPARENT): The vessel rim has single upper and lower horizontal engraved lines, and the panel between has four elongated rectangular zones filled with cross-hatched lines (Figure 44). The ends of these zones have a single short vertical line that extends to meet the lower horizontal engraved line that encircles the vessel (see Suhm and Jelks 1962:Plate 4d).

PIGMENT USE AND LOCATION ON VESSEL: none

TYPE AND VARIETY (IF KNOWN): Barkman Engraved 
SITE NAME OR SITE NUMBER: Hatchel (41BW3)

VESSEL NO.: 6-1-22; Burial Plot 2, Burial 20

VESSEL FORM: Jar

NON-PLASTICS AND PASTE: grog

RIM AND LIP FORM: Everted rim and rounded lip

CORE COLOR: $\mathrm{G}$ (fired in a reducing environment and cooled in the open air)

INTERIOR SURFACE COLOR: very dark grayish-brown; fire clouds on the rim and body

EXTERIOR SURFACE COLOR: dark yellowish-brown; fire clouds on the rim, body, and base

WALL THICKNESS (IN MM): rim, $5.7 \mathrm{~mm}$; body, $6.2 \mathrm{~mm}$

INTERIOR SURFACE TREATMENT:

smoothed on the rim and upper body

EXTERIOR SURFACE TREATMENT: none

HEIGHT (IN CM): 15.0

ORIFICE DIAMETER (IN CM): 15.2

DIAMETER AT BOTTOM OF RIM OR NECK (IN CM): 14.2

BASE DIAMETER (IN CM) AND SHAPE OF

BASE: $7.1 \mathrm{~cm}$; circular and flat

ESTIMATED VOLUME (IN LITERS): 1.4

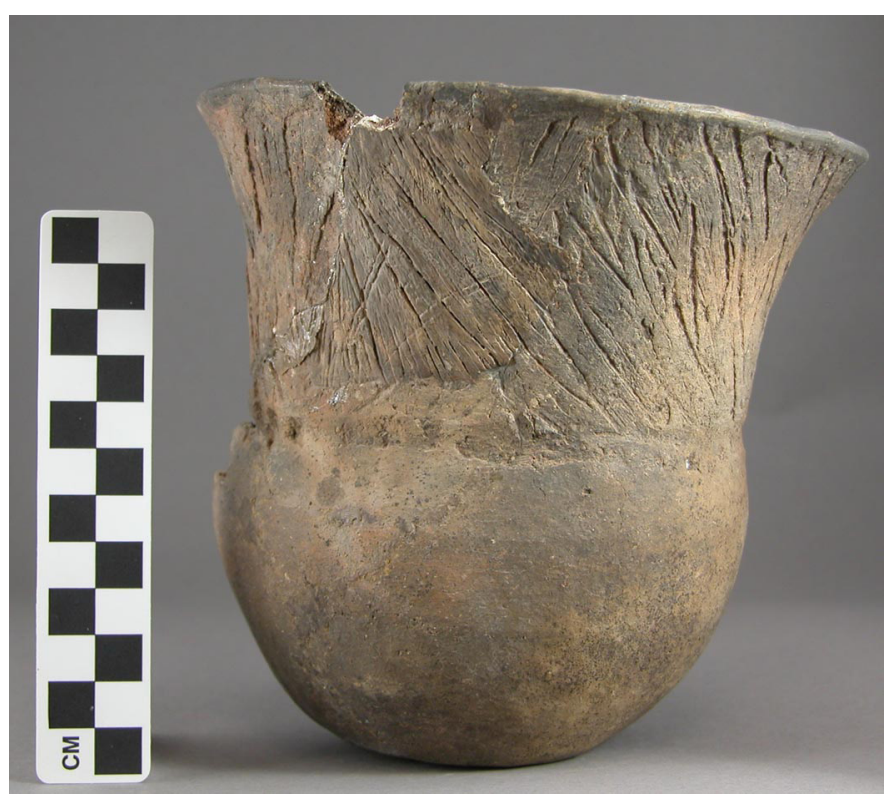

Figure 45. Brushed-incised and punctated jar (6-122) in Burial 20 in Burial Plot 2 at the Hatchel site. Photograph courtesy of TARL.

DECORATION (INCLUDING MOTIF AND ELEMENTS WHEN APPARENT): The vessel rim is decorated with diagonal brushed-incised marks and lines (Figure 45). There is a row of tool punctations at the rim-body juncture.

PIGMENT USE AND LOCATION ON VESSEL: none

TYPE AND VARIETY (IF KNOWN): Unidentified utility ware 
SITE NAME OR SITE NUMBER: Hatchel (41BW3)

VESSEL NO.: 6-1-23; Burial Plot 2, Burial 21

VESSEL FORM: Jar

NON-PLASTICS AND PASTE: grog

RIM AND LIP FORM: Everted rim and rounded lip; four appliqued loop handles (17 x $9 \mathrm{~mm}$ in length and width) (Figure 46)

CORE COLOR: F (fired in a reducing environment and cooled in the open air)

INTERIOR SURFACE COLOR: dark reddishbrown; fire clouds on the rim

EXTERIOR SURFACE COLOR: dark reddishbrown; fire clouds on the rim and body

WALL THICKNESS (IN MM): rim, $4.9 \mathrm{~mm}$

INTERIOR SURFACE TREATMENT: smoothed

EXTERIOR SURFACE TREATMENT: none

HEIGHT (IN CM): 8.2

ORIFICE DIAMETER (IN CM): 11.4

DIAMETER AT BOTTOM OF RIM OR NECK (IN CM): 8.8

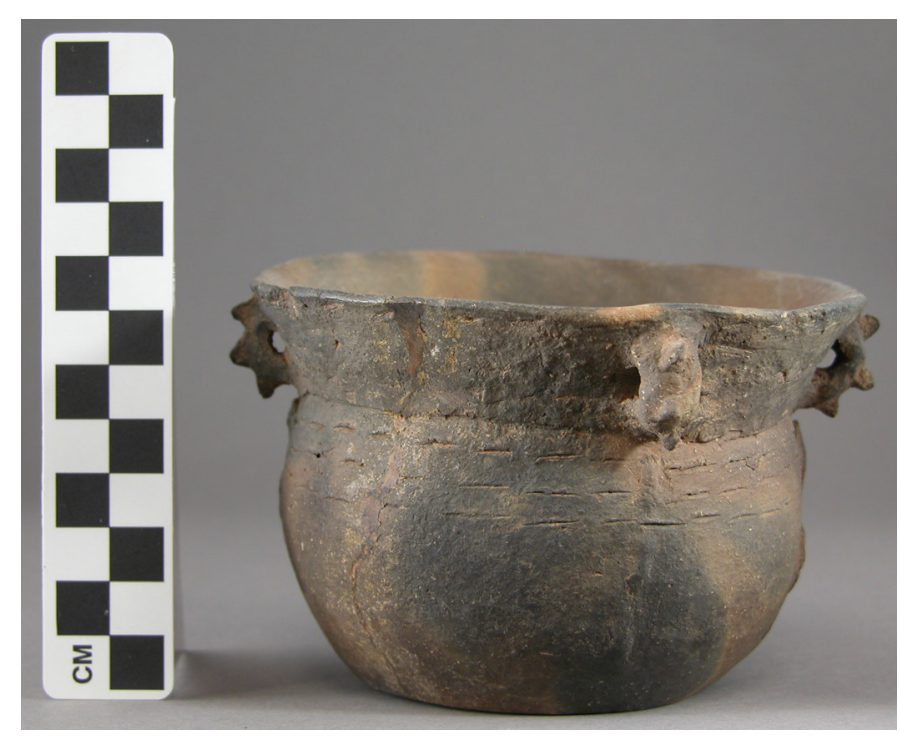

Figure 46. Nash Neck Banded jar (6-1-23) in Burial 21 in Burial Plot 2 at the Hatchel site. Photograph courtesy of TARL.

BASE DIAMETER (IN CM) AND SHAPE OF BASE: $6.5 \mathrm{~cm}$; circular and flat

ESTIMATED VOLUME (IN LITERS): 0.56

DECORATION (INCLUDING MOTIF AND ELEMENTS WHEN APPARENT): The rim has a single row of tool punctations under the vessel lip as well as smoothed neck banded coils (Figure 46). The upper vessel body has three rows of linear tool punctations as well as four vertical appliqued ridges placed under the loop handles. These ridges are divided into upper (amidst the punctated rows) and lower sections (below the tool punctated rows) (Figure 46).

PIGMENT USE AND LOCATION ON VESSEL: none

TYPE AND VARIETY (IF KNOWN): Nash Neck Banded 
SITE NAME OR SITE NUMBER: Hatchel (41BW3)

VESSEL NO.: 6-1-24; Burial Plot 2, Burial 21

VESSEL FORM: Jar with five rim peaks (Figure 47)

NON-PLASTICS AND PASTE: grog

RIM AND LIP FORM: Everted rim and rounded lip

CORE COLOR: A (fired and cooled in an oxidizing environment)

INTERIOR SURFACE COLOR: reddish-brown; fire clouds on the rim

EXTERIOR SURFACE COLOR: reddish-brown; fire clouds on the body

WALL THICKNESS (IN MM): rim, $4.0 \mathrm{~mm}$

INTERIOR SURFACE TREATMENT: smoothed

EXTERIOR SURFACE TREATMENT:

smoothed on the body

HEIGHT (IN CM): 9.2; $9.5 \mathrm{~cm}$ at the rim peak

ORIFICE DIAMETER (IN CM): 11.5

DIAMETER AT BOTTOM OF RIM OR NECK (IN CM): 8.8

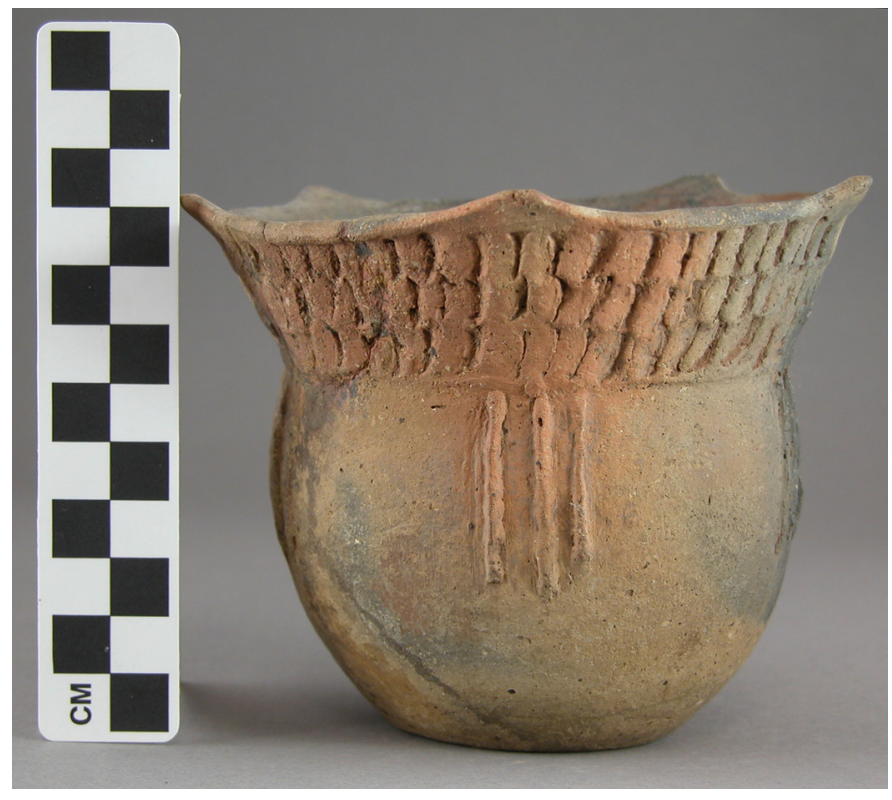

Figure 47. Nash Neck Banded jar (6-1-24) in Burial 21 in Burial Plot 2 at the Hatchel site. Photograph courtesy of TARL.

BASE DIAMETER (IN CM) AND SHAPE OF BASE: $5.1 \mathrm{~cm}$; circular and flat

ESTIMATED VOLUME (IN LITERS): 0.64

DECORATION (INCLUDING MOTIF AND ELEMENTS WHEN APPARENT): The rim has three horizontal neck banded coils (Figure 47). The vessel body has five sets of three vertical appliqued ridges that extend to the mid-body; these appliqued ridges are placed on the vessel body underneath the rim peaks.

PIGMENT USE AND LOCATION ON VESSEL: none

TYPE AND VARIETY (IF KNOWN): Nash Neck Banded 
SITE NAME OR SITE NUMBER: Hatchel (41BW3)

VESSEL NO.: 6-1-25; Burial Plot 2, Burial 21

VESSEL FORM: Jar

NON-PLASTICS AND PASTE: grog

RIM AND LIP FORM: Everted rim and rounded lip

CORE COLOR: F (fired in a reducing environment and cooled in the open air)

INTERIOR SURFACE COLOR: dark reddishbrown; fire clouds on the rim, body, and base

EXTERIOR SURFACE COLOR: dark reddishbrown; fire clouds on the rim, body, and base

WALL THICKNESS (IN MM): rim, 4.6 mm

INTERIOR SURFACE TREATMENT: none

EXTERIOR SURFACE TREATMENT: none

HEIGHT (IN CM): 9.5

ORIFICE DIAMETER (IN CM): 9.8

DIAMETER AT BOTTOM OF RIM OR NECK (IN CM): 7.6

BASE DIAMETER (IN CM) AND SHAPE OF BASE: $4.5 \mathrm{~cm}$; circular and flat

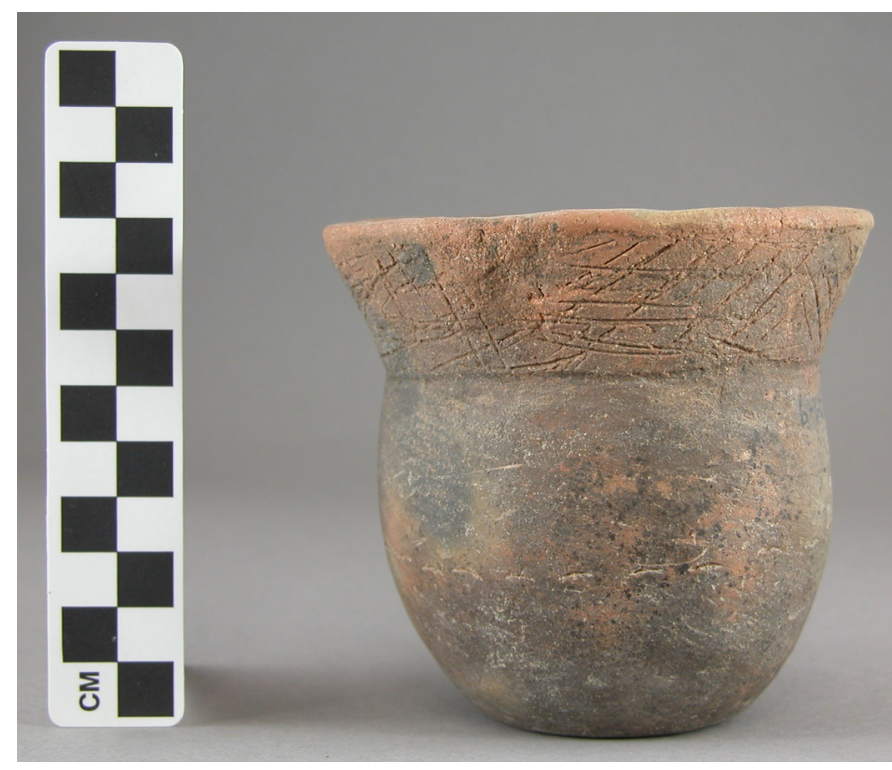

Figure 48. Incised-punctated jar (6-1-25) in Burial 21 in Burial Plot 2 at the Hatchel site. Photograph courtesy of TARL.

\section{ESTIMATED VOLUME (IN LITERS): 0.56}

DECORATION (INCLUDING MOTIF AND ELEMENTS WHEN APPARENT): The rim is decorated with diagonal and cross-hatched incised lines, and there is a broad horizontal incised line at the rim-body juncture (Figure 48). There is a single linear fingernail punctated row on the vessel at mid-body.

PIGMENT USE AND LOCATION ON VESSEL: none

TYPE AND VARIETY (IF KNOWN): Unidentified utility ware 
SITE NAME OR SITE NUMBER: Hatchel (41BW3)

VESSEL NO.: 6-1-27; Burial Plot 2, Burial 22

VESSEL FORM: Jar, lower body and base section (Figure 49a)

NON-PLASTICS AND PASTE: grog

RIM AND LIP FORM: N/A

CORE COLOR: B (fired and cooled in a reducing environment)

INTERIOR SURFACE COLOR: very dark grayishbrown

EXTERIOR SURFACE COLOR: very dark grayish-brown; organic residue on the body

WALL THICKNESS (IN MM): body, $4.3 \mathrm{~mm}$

INTERIOR SURFACE TREATMENT: smoothed

EXTERIOR SURFACE TREATMENT: smoothed

HEIGHT (IN CM): 7.6+

ORIFICE DIAMETER (IN CM): 15.4

DIAMETER AT BOTTOM OF RIM OR NECK (IN $\mathrm{CM})$ : N/A

BASE DIAMETER (IN CM) AND SHAPE OF

BASE: $6.4 \mathrm{~cm}$; circular and flat

ESTIMATED VOLUME (IN LITERS): 0.7+

DECORATION (INCLUDING MOTIF AND ELEMENTS WHEN APPARENT): The vessel body is plain (Figure 49a), but the vessel base has four curvilinear engraved zones filled with cross-hatched engraved lines (Figure 49b).

PIGMENT USE AND LOCATION ON VESSEL: none

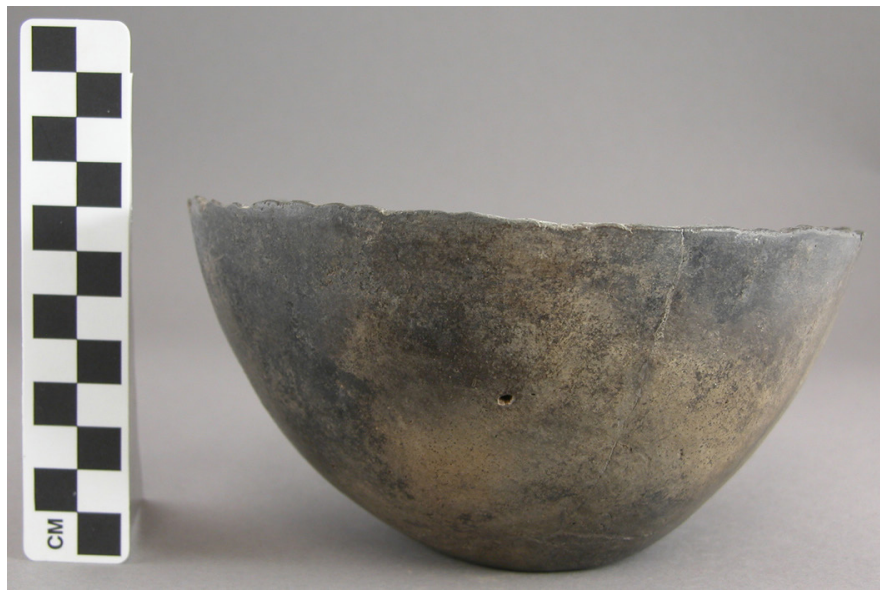

a

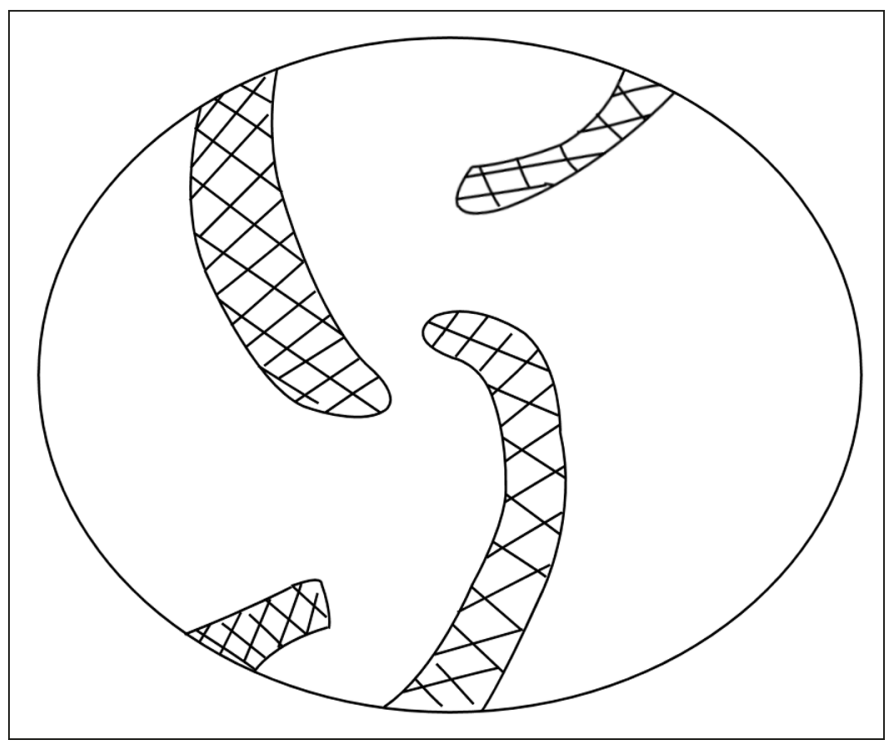

b

Figure 49. Plain jar vessel section (6-1-27): a, photograph, courtesy of TARL; $b$, engraved decorative elements on vessel base.

TYPE AND VARIETY (IF KNOWN): Unidentified fine ware 
SITE NAME OR SITE NUMBER: Hatchel (41BW3)

VESSEL NO.: 6-1-28; Burial Plot 2, Burial 23

VESSEL FORM: Jar with opposing suspension holes (1.0 mm in diameter) (Figure 50)

NON-PLASTICS AND PASTE: grog

RIM AND LIP FORM: Direct rim and rounded lip

CORE COLOR: B (fired and cooled in a reducing environment)

INTERIOR SURFACE COLOR: very dark grayish-brown

EXTERIOR SURFACE COLOR: very dark grayish-brown

WALL THICKNESS (IN MM): rim, $2.5 \mathrm{~mm}$

INTERIOR SURFACE TREATMENT: none

EXTERIOR SURFACE TREATMENT: smoothed

HEIGHT (IN CM): 4.0

ORIFICE DIAMETER (IN CM): 2.6

DIAMETER AT BOTTOM OF RIM OR NECK (IN CM): 2.7

BASE DIAMETER (IN CM) AND SHAPE OF BASE: $3.5 \mathrm{~cm}$; circular-concave

ESTIMATED VOLUME (IN LITERS): 0.1

DECORATION (INCLUDING MOTIF AND ELEMENTS WHEN APPARENT): Plain (Figure 50)

PIGMENT USE AND LOCATION ON VESSEL: none

TYPE AND VARIETY (IF KNOWN): Unidentified plain ware

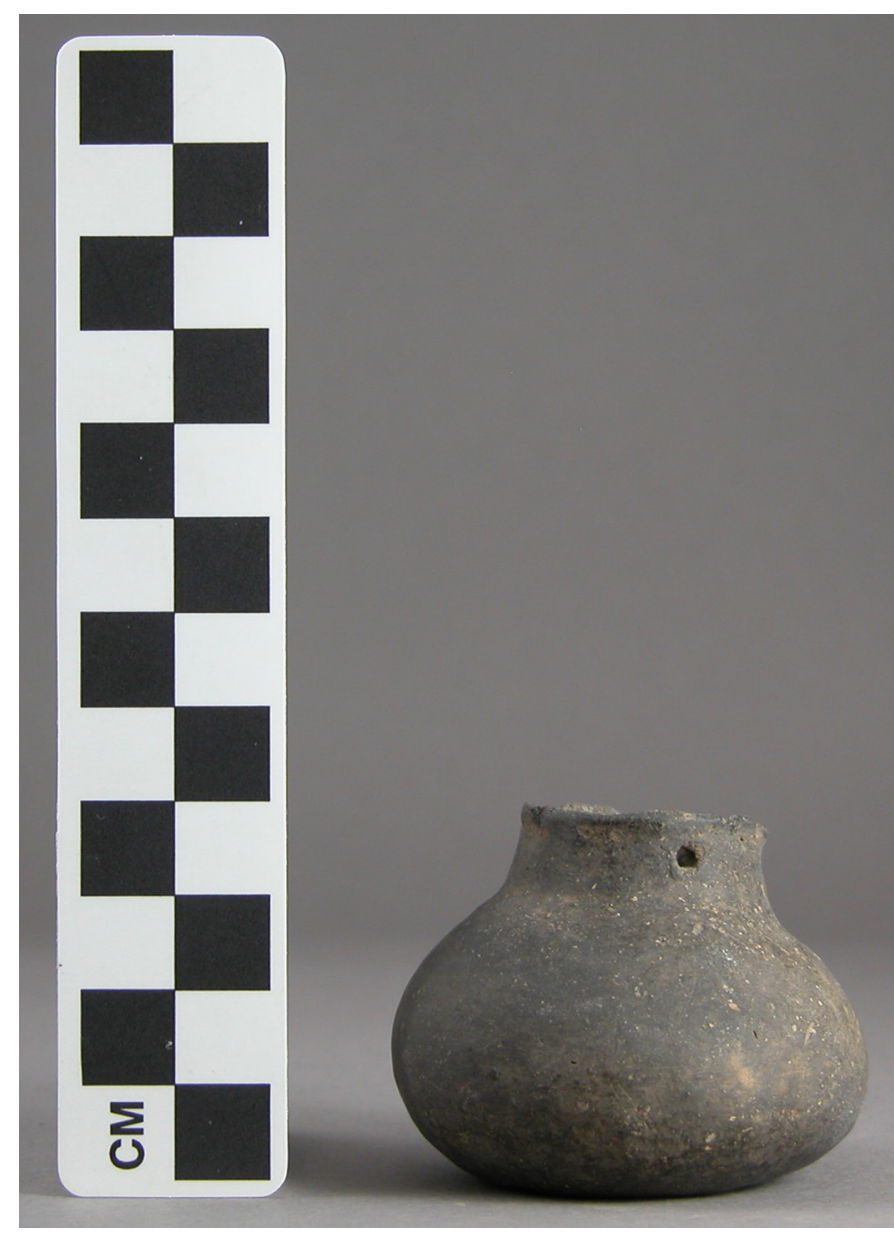

Figure 50. Plain jar (6-1-28) in Burial Plot 2, Burial 23 at the Hatchel site. Photograph courtesy of TARL. 
SITE NAME OR SITE NUMBER: Hatchel (41BW3)

VESSEL NO.: 6-1-29; Burial Plot 2, Burial 23

VESSEL FORM: Carinated bowl

NON-PLASTICS AND PASTE: grog and bone

RIM AND LIP FORM: Everted rim and rounded lip

CORE COLOR: $\mathrm{G}$ (fired in a reducing environment and cooled in the open air)

INTERIOR SURFACE COLOR: very dark grayish-brown; fire clouds on the body

EXTERIOR SURFACE COLOR: dark yellowish-brown; fire clouds on the rim, body, and base

WALL THICKNESS (IN MM): rim, $4.8 \mathrm{~mm}$

INTERIOR SURFACE TREATMENT: burnished on the rim; smoothed on the body

EXTERIOR SURFACE TREATMENT: burnished

HEIGHT (IN CM): 10.2

ORIFICE DIAMETER (IN CM): 15.8

DIAMETER AT BOTTOM OF RIM OR NECK (IN CM): 16.2

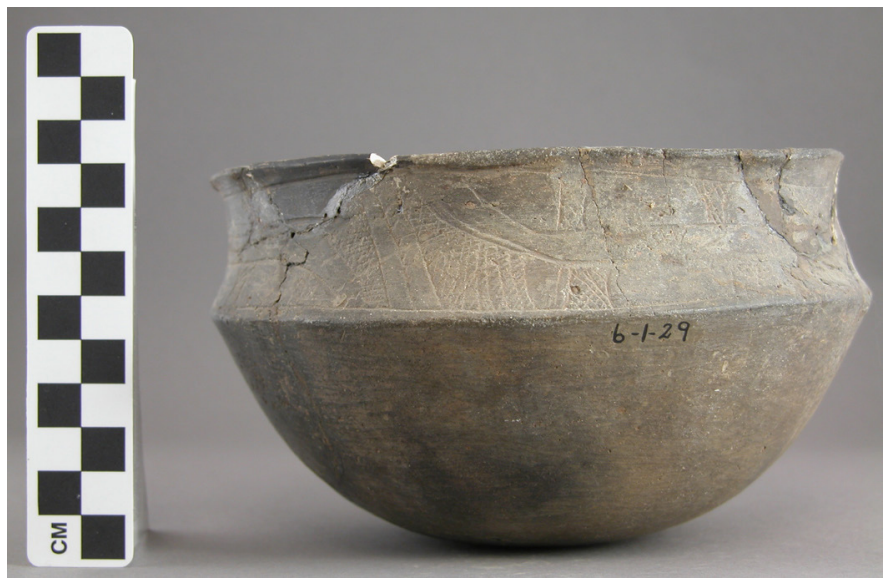

Figure 51. Barkman Engraved carinated bowl (6-129) in Burial 23 in Burial Plot 2 at the Hatchel site. Photograph courtesy of TARL.

BASE DIAMETER (IN CM) AND SHAPE OF BASE: $7.0 \mathrm{~cm}$; circular and rounded ESTIMATED VOLUME (IN LITERS): 1.0

DECORATION (INCLUDING MOTIF AND ELEMENTS WHEN APPARENT): The rim panel has an engraved motif repeated twice around the vessel. The motif consists of horizontal and curvilinear scrolls divided by two diagonal engraved lines (Figure 51). The scrolls have cross-hatched engraved brackets that interlock with upper and lower horizontal engraved lines at the top and bottom of the engraved rim panel.

PIGMENT USE AND LOCATION ON VESSEL: none

TYPE AND VARIETY (IF KNOWN): Barkman Engraved 
SITE NAME OR SITE NUMBER: Hatchel (41BW3)

VESSEL NO.: 6-1-30; Burial Plot 2, Burial 23

VESSEL FORM: Carinated bowl

NON-PLASTICS AND PASTE: grog

RIM AND LIP FORM: Inverted rim and rounded, exterior folded lip

CORE COLOR: $\mathrm{G}$ (fired in a reducing environment and cooled in the open air)

INTERIOR SURFACE COLOR: black

EXTERIOR SURFACE COLOR: dark reddish-brown; fire clouds on the rim, body, and base

WALL THICKNESS (IN MM): rim, $5.1 \mathrm{~mm}$

INTERIOR SURFACE TREATMENT: burnished on the rim; smoothed on the body

EXTERIOR SURFACE TREATMENT: burnished

HEIGHT (IN CM): 7.0

ORIFICE DIAMETER (IN CM): 12.2

DIAMETER AT BOTTOM OF RIM OR NECK (IN CM): 13.0

BASE DIAMETER (IN CM) AND SHAPE OF BASE: $5.1 \mathrm{~cm}$; circular and rounded

ESTIMATED VOLUME (IN LITERS): 0.51

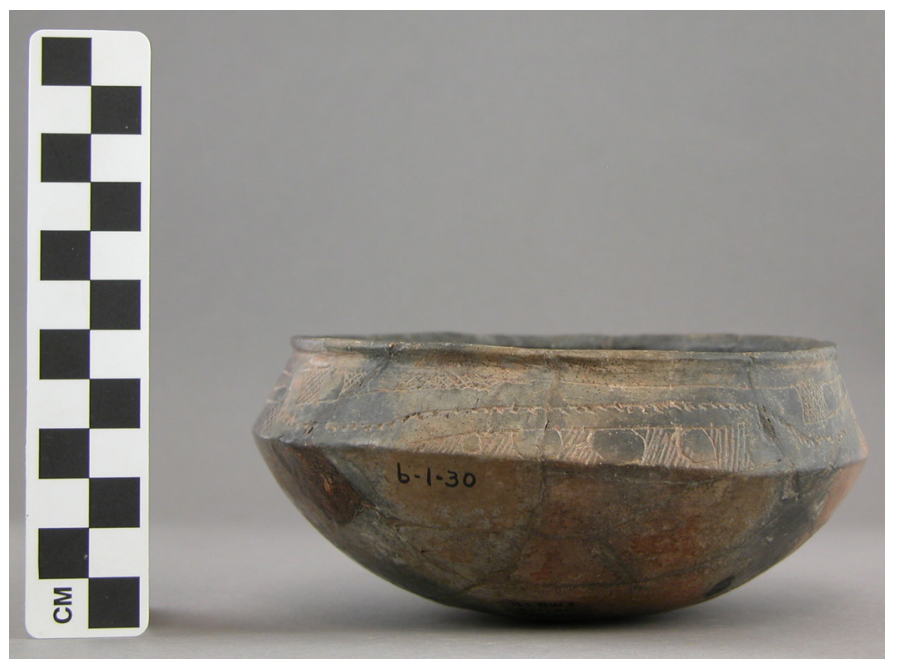

Figure 52. Hodges Engraved, var. Armour carinated bowl (6-1-30) in Burial 23 in Burial Plot 2 at the Hatchel site. Photograph courtesy of TARL.

DECORATION (INCLUDING MOTIF AND ELEMENTS WHEN APPARENT): The rim panel has an engraved meandering scroll motif marked by a scroll center line with downward-pointing excised tick marks (Figure 52). The upper and lower scroll fill zones have hatched and cross-hatched bracket elements that form a series of negative ovals in the scroll fill zones.

PIGMENT USE AND LOCATION ON VESSEL: none

TYPE AND VARIETY (IF KNOWN): Hodges Engraved, var. Armour (Schambach and Miller 1984:122) 
SITE NAME OR SITE NUMBER: Hatchel (41BW3)

VESSEL NO.: 6-1-31; Burial Plot 4, Burial 34

VESSEL FORM: Carinated bowl

NON-PLASTICS AND PASTE: grog

RIM AND LIP FORM: Inverted rim and rounded lip

CORE COLOR: $\mathrm{G}$ (fired in a reducing environment and cooled in the open air)

INTERIOR SURFACE COLOR: dark grayish-brown

EXTERIOR SURFACE COLOR: reddish-brown; fire clouds on the rim, body, and base

WALL THICKNESS (IN MM): rim, $4.2 \mathrm{~mm}$

INTERIOR SURFACE TREATMENT: smoothed

EXTERIOR SURFACE TREATMENT: burnished

HEIGHT (IN CM): 7.0

ORIFICE DIAMETER (IN CM): 15.2

DIAMETER AT BOTTOM OF RIM OR NECK (IN CM): 16.8

BASE DIAMETER (IN CM) AND SHAPE OF

BASE: $5.1 \mathrm{~cm}$; circular and rounded

ESTIMATED VOLUME (IN LITERS): 0.64

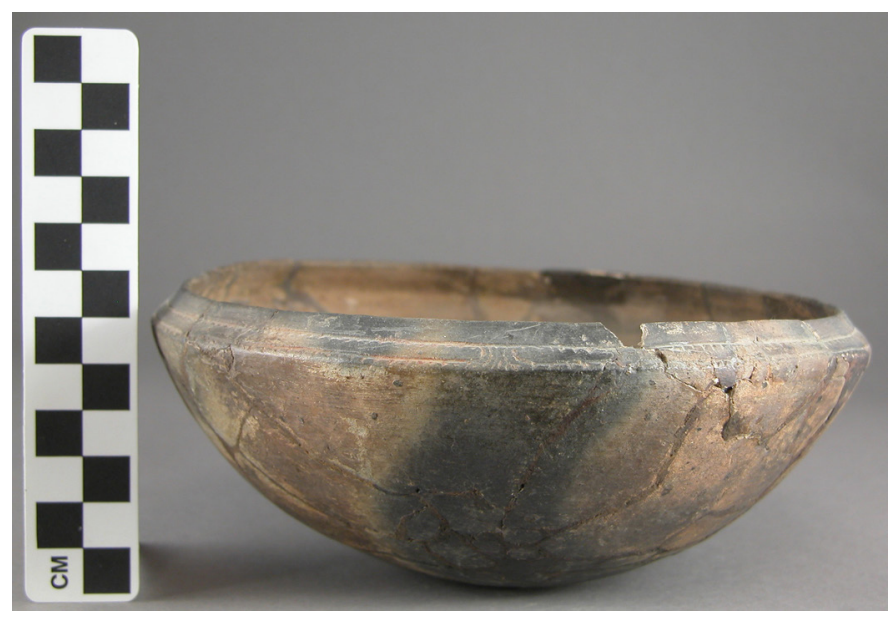

Figure 53. Simms Engraved carinated bowl (6-131) in Burial 34 in Burial Plot 4 at the Hatchel site. Photograph courtesy of TARL.

DECORATION (INCLUDING MOTIF AND ELEMENTS WHEN APPARENT): The rim panel is defined by single upper and lower horizontal engraved lines with downward-pointing excised tick marks. The panel is divided into four sections by brackets filled with vertical to curvilinear engraved lines (Figure 53).

PIGMENT USE AND LOCATION ON VESSEL: red pigment in the engraved lines

TYPE AND VARIETY (IF KNOWN): Simms Engraved 
SITE NAME OR SITE NUMBER: Hatchel (41BW3)

VESSEL NO.: 6-1-33a; Burial Plot 2

VESSEL FORM: Carinated bowl

NON-PLASTICS AND PASTE: grog

RIM AND LIP FORM: Direct rim and flat lip

CORE COLOR: $\mathrm{G}$ (fired in a reducing environment and cooled in the open air)

INTERIOR SURFACE COLOR: dark grayish-brown; fire clouds on the body

EXTERIOR SURFACE COLOR: yellowish-

brown; fire clouds on the rim, body, and base

WALL THICKNESS (IN MM): rim, $4.8 \mathrm{~mm}$; body, $5.4 \mathrm{~mm}$

INTERIOR SURFACE TREATMENT:

smoothed

EXTERIOR SURFACE TREATMENT: burnished

HEIGHT (IN CM): 7.8

ORIFICE DIAMETER (IN CM): 17.8

DIAMETER AT BOTTOM OF RIM OR NECK (IN CM): 17.8

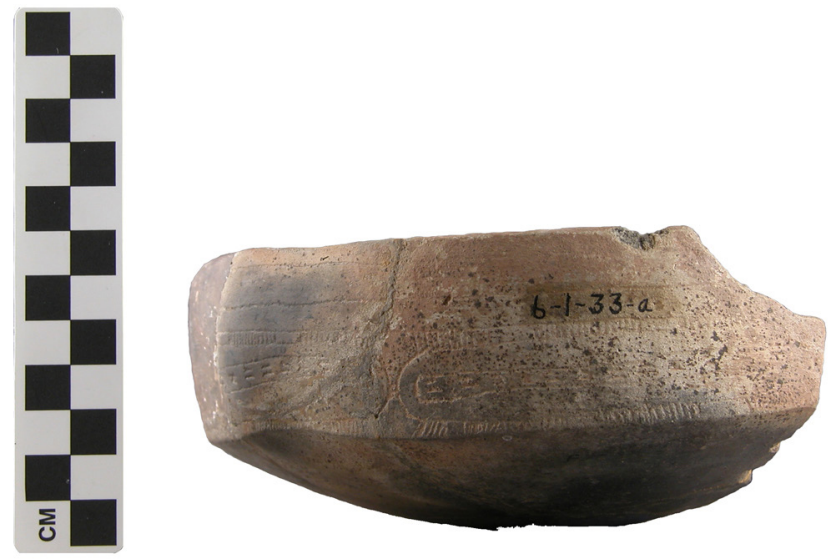

Figure 54. Barkman Engraved carinated bowl (6-133a) in Burial Plot 2 at the Hatchel site. Photograph courtesy of TARL.

BASE DIAMETER (IN CM) AND SHAPE OF BASE: $6.4 \mathrm{~cm}$; circular and rounded

ESTIMATED VOLUME (IN LITERS): 0.83

DECORATION (INCLUDING MOTIF AND ELEMENTS WHEN APPARENT): The upper part of the rim is decorated with two widely-spaced horizontal engraved lines. These occur above a motif, probably repeated four times around the vessel, defined by an upper narrow horizontal zone filled with vertical engraved lines, enclosed rectangle elements filled with two rows of excised punctations, and a discontinuous zone of short vertical engraved lines above the vessel carination (Figure 54). The motifs are divided by a large and open bracket element.

PIGMENT USE AND LOCATION ON VESSEL: none

TYPE AND VARIETY (IF KNOWN): Barkman Engraved 
SITE NAME OR SITE NUMBER: Hatchel (41BW3)

VESSEL NO.: 6-1-33d; Burial Plot 3 (Square D-1)

VESSEL FORM: Carinated bowl

NON-PLASTICS AND PASTE: grog and bone

RIM AND LIP FORM: Direct rim and rounded, exterior folded lip

CORE COLOR: $\mathrm{G}$ (fired in a reducing environment and cooled in the open air)

INTERIOR SURFACE COLOR: dark grayish-brown; fire clouds on the body

EXTERIOR SURFACE COLOR: reddish-brown; fire clouds on the rim, body, and base

WALL THICKNESS (IN MM): rim, $5.6 \mathrm{~mm}$; body, $4.9 \mathrm{~mm}$; base, $5.7 \mathrm{~mm}$

INTERIOR SURFACE TREATMENT: smoothed

EXTERIOR SURFACE TREATMENT: burnished

HEIGHT (IN CM): 14.7

ORIFICE DIAMETER (IN CM): 23.0

DIAMETER AT BOTTOM OF RIM OR NECK (IN CM): 23.0

BASE DIAMETER (IN CM) AND SHAPE OF BASE: $9.1 \mathrm{~cm}$; circular and flat

ESTIMATED VOLUME (IN LITERS): 3.0

DECORATION (INCLUDING MOTIF AND ELEMENTS WHEN APPARENT): The upper part of the rim has two widely-spaced horizontal engraved lines. Below these lines are a series-likely four-of rectangular engraved panels (Figure 55). The rectangular outlines of the panel are narrow zones filled with cross-hatched engraved lines. Inside each of these rectangular panels are two smaller rectangular elements with a series of short vertical columns with either one or two horizontal engraved lines. The panels are divided from each other by a single vertical line and a narrow vertical column with two sets of horizontal engraved lines (Figure 55).

PIGMENT USE AND LOCATION ON VESSEL: none

TYPE AND VARIETY (IF KNOWN): Barkman Engraved (see Suhm and Jelks 1962:Plate 4j)

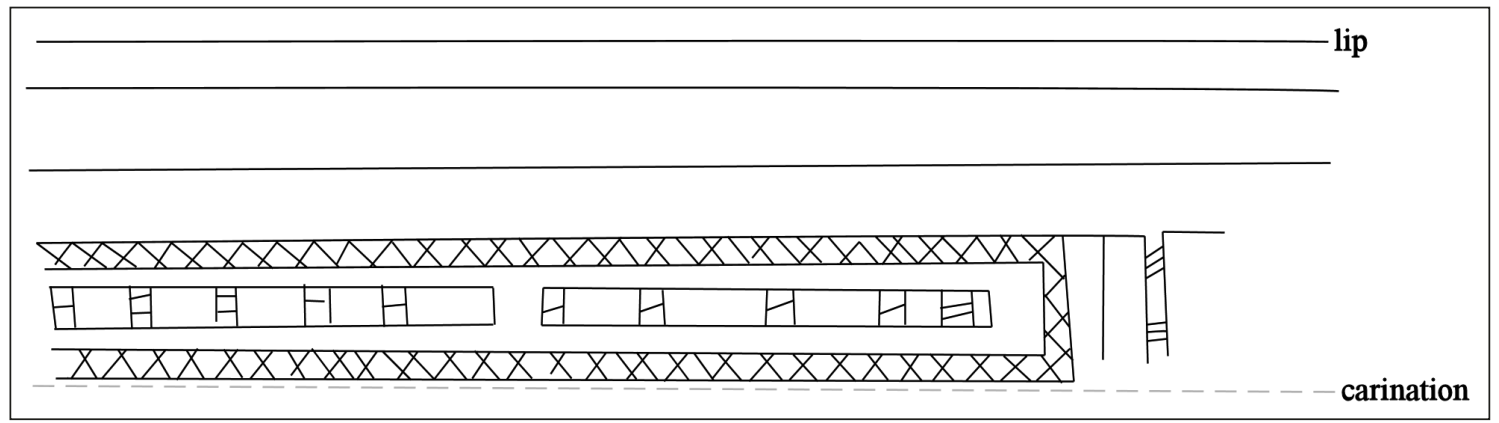

Figure 55. Decorative motif on Barkman Engraved carinated bowl (6-1-33d) from Burial Plot 3 at the Hatchel site. 
SITE NAME OR SITE NUMBER: Hatchel (41BW3)

VESSEL NO.: 6-1-33e; Burial Plot 3 (Square D-1)

VESSEL FORM: Jar with short rim

NON-PLASTICS AND PASTE: grog

RIM AND LIP FORM: Everted rim and rounded lip

CORE COLOR: $\mathrm{G}$ (fired in a reducing environment and cooled in the open air)

INTERIOR SURFACE COLOR: very dark grayish-brown; fire clouds on the body

EXTERIOR SURFACE COLOR: dark yellowishbrown; fire clouds on the rim, body, and base

WALL THICKNESS (IN MM): rim, $4.8 \mathrm{~mm}$; body, $5.7 \mathrm{~mm}$

INTERIOR SURFACE TREATMENT: smoothed

EXTERIOR SURFACE TREATMENT: none

HEIGHT (IN CM): 10.8

ORIFICE DIAMETER (IN CM): 13.8

DIAMETER AT BOTTOM OF RIM OR NECK (IN CM): 13.2

BASE DIAMETER (IN CM) AND SHAPE OF BASE: 7.6; circular and flat

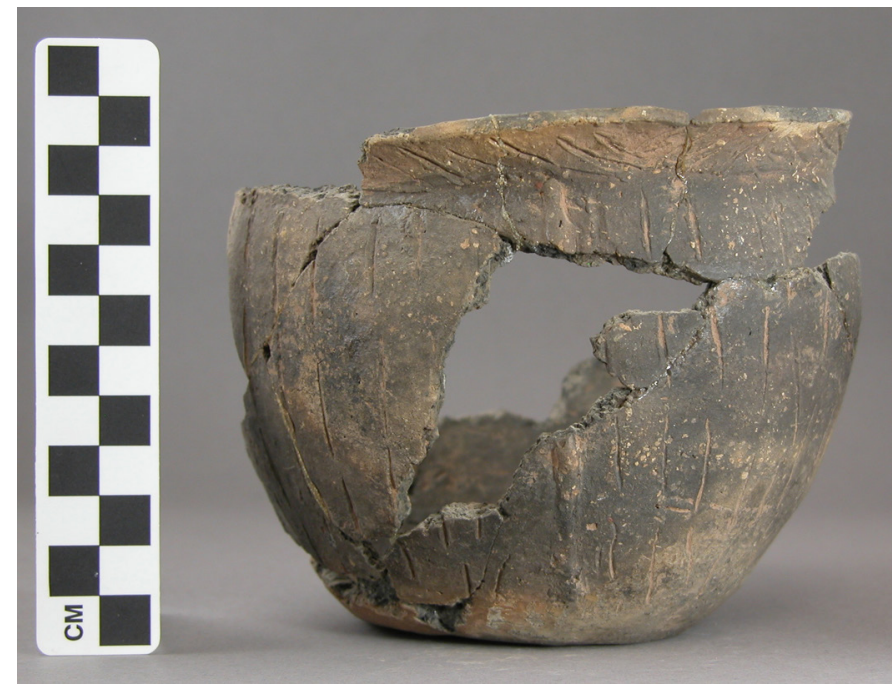

Figure 56. Incised-appliqued jar (6-1-33e) from Burial Plot 3 at the Hatchel site. Photograph courtesy of TARL.

ESTIMATED VOLUME (IN LITERS): 0.9

DECORATION (INCLUDING MOTIF AND ELEMENTS WHEN APPARENT): The rim is decorated with diagonal opposed incised lines (Figure 56). The vessel body has a series of discontinuous vertical incised lines divided by (four?) vertical appliqued ridges.

PIGMENT USE AND LOCATION ON VESSEL: none

TYPE AND VARIETY (IF KNOWN): Unidentified utility ware 
SITE NAME OR SITE NUMBER: Hatchel (41BW3)

VESSEL NO.: 6-1-33f; Burial Plot 3 (Square D-1)

VESSEL FORM: Jar, lower body section

NON-PLASTICS AND PASTE: grog

RIM AND LIP FORM: N/A

CORE COLOR: $\mathrm{G}$ (fired in a reducing environment and cooled in the open air)

INTERIOR SURFACE COLOR: very dark grayish-brown; fire clouds on the base

EXTERIOR SURFACE COLOR: dark yellowishbrown; fire clouds on the body and base

WALL THICKNESS (IN MM): body, $6.4 \mathrm{~mm}$

INTERIOR SURFACE TREATMENT: smoothed

EXTERIOR SURFACE TREATMENT:

smoothed

HEIGHT (IN CM): 7.6+

ORIFICE DIAMETER (IN CM): 12.7

DIAMETER AT BOTTOM OF RIM OR NECK (IN CM): N/A

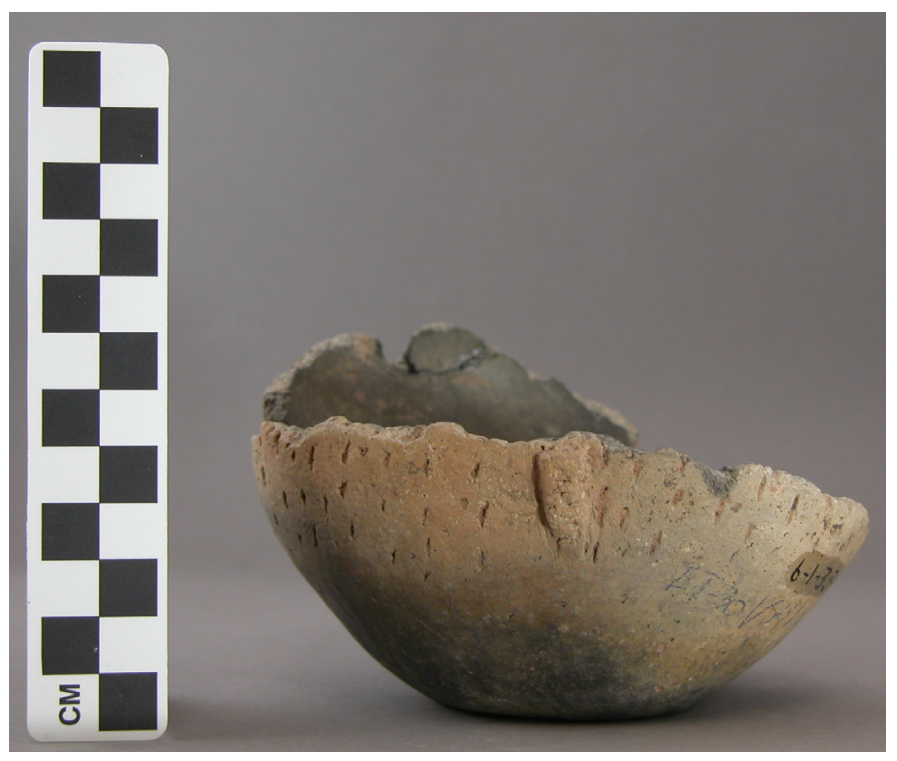

Figure 57. Punctated-appliqued jar section (6-133f) in Burial Plot 3 at the Hatchel site. Photograph courtesy of TARL.

ESTIMATED VOLUME (IN LITERS): 0.58+

DECORATION (INCLUDING MOTIF AND ELEMENTS WHEN APPARENT): The vessel body is decorated with vertical rows of linear tool punctations divided by vertical appliqued fillets that extend to within $5.1 \mathrm{~cm}$ of the vessel base (Figure 57).

PIGMENT USE AND LOCATION ON VESSEL: none

TYPE AND VARIETY (IF KNOWN): Unidentified utility ware 


\section{Village Area Vessels}

A number of the ceramic vessels from the Hatchel site are from burial features in Village Plots 1 and 2 south and southwest of the platform mound (see Figure 1b; see also Perttula 2005:Figures 7 and 8).

SITE NAME OR SITE NUMBER: Hatchel (41BW3)

VESSEL NO.: 6-1-33b; North-Northwest of the platform mound (Square I-6)

VESSEL FORM: Jar, lower body/base section

NON-PLASTICS AND PASTE: grog

RIM AND LIP FORM: N/A

CORE COLOR: B (fired and cooled in a reducing environment)

INTERIOR SURFACE COLOR: dark grayishbrown; fire clouds on the body

EXTERIOR SURFACE COLOR: dark grayishbrown

WALL THICKNESS (IN MM): body, $6.0 \mathrm{~mm}$

INTERIOR SURFACE TREATMENT: smoothed

EXTERIOR SURFACE TREATMENT:

smoothed

HEIGHT (IN CM): 7.0+

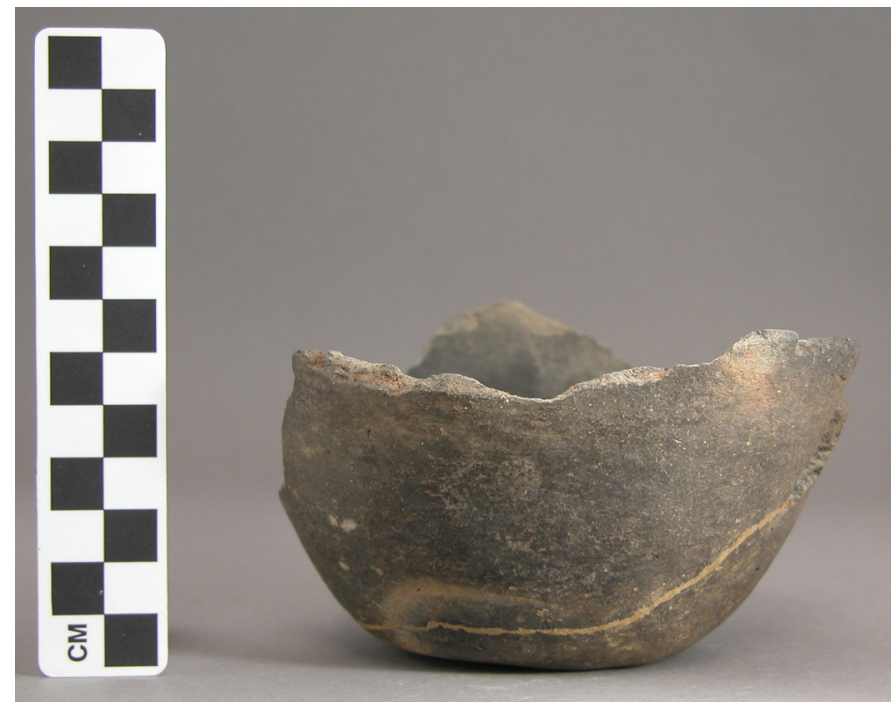

Figure 58. Plain jar section (6-1-33b) in Village area north-northwest of the platform mound at the Hatchel site. Photograph courtesy of TARL.

ORIFICE DIAMETER (IN CM): 13.5

DIAMETER AT BOTTOM OF RIM OR NECK (IN CM): N/A

BASE DIAMETER (IN CM) AND SHAPE OF BASE: $6.4 \mathrm{~cm}$; circular and flat

ESTIMATED VOLUME (IN LITERS): 0.57+

DECORATION (INCLUDING MOTIF AND ELEMENTS WHEN APPARENT): Plain (Figure 58)

PIGMENT USE AND LOCATION ON VESSEL: none

TYPE AND VARIETY (IF KNOWN): Unidentified plain ware 
SITE NAME OR SITE NUMBER: Hatchel (41BW3)

VESSEL NO.: 6-4-580; Village Plot 1, Burial 2

VESSEL FORM: Bottle

NON-PLASTICS AND PASTE: grog

RIM AND LIP FORM: Direct rim and rounded lip

CORE COLOR: B (fired and cooled in a reducing environment)

INTERIOR SURFACE COLOR: very dark grayish-brown

EXTERIOR SURFACE COLOR: very dark grayish-brown

WALL THICKNESS (IN MM): rim, $5.1 \mathrm{~mm}$

INTERIOR SURFACE TREATMENT: none

EXTERIOR SURFACE TREATMENT: burnished

HEIGHT (IN CM): 20.9

ORIFICE DIAMETER (IN CM): 3.6

DIAMETER AT BOTTOM OF RIM OR NECK

(IN CM): 5.2 ; maximum body diameter is $13.3 \mathrm{~cm}$

BASE DIAMETER (IN CM) AND SHAPE OF

BASE: $7.6 \mathrm{~cm}$; circular and rounded

ESTIMATED VOLUME (IN LITERS): 0.63

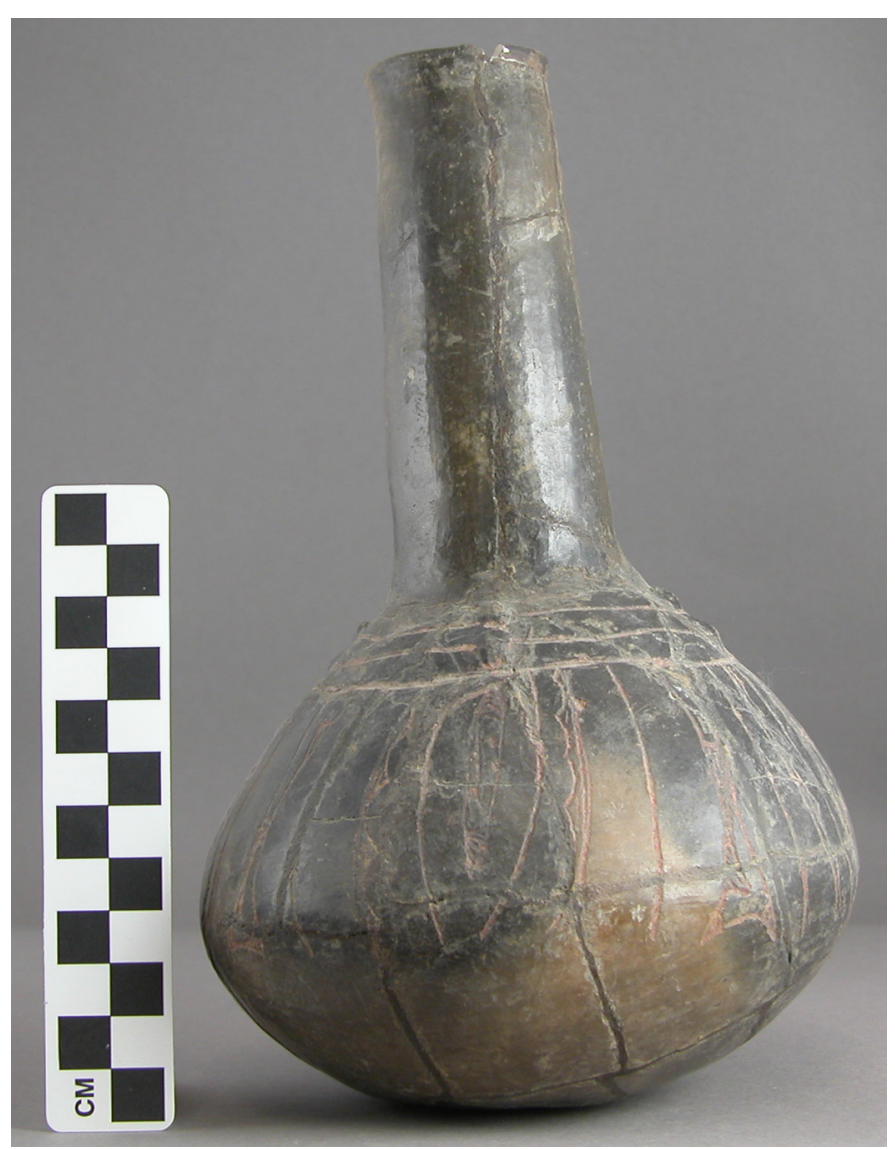

Figure 59. Hatchel Engraved bottle (6-4-580) in Burial 2 in Village Plot 1 at the Hatchel site.

DECORATION (INCLUDING MOTIF AND ELEMENTS WHEN APPARENT): There are two horizontal engraved lines at the top of the vessel body; these intersect four sets of vertical appliqued ridges (Figure 59). The remainder of the vessel has an engraved motif repeated four times. The central element in the motif is an oval with a negative S-shaped element at its center formed by excising. This oval has on either side a single curvilinear engraved line; a single curvilinear engraved line with pendant triangle elements on either side; another curvilinear engraved line on either side of the central oval; and an excised bracket with a negative S-shaped element outlined by the excising (Figure 59).

PIGMENT USE AND LOCATION ON VESSEL: red pigment in engraved lines

TYPE AND VARIETY (IF KNOWN): Hatchel Engraved 
SITE NAME OR SITE NUMBER: Hatchel (41BW3)

VESSEL NO.: 6-4-581; Village Plot 1, Burial 2

VESSEL FORM: Bowl with opposed suspension holes (2.6 $\mathrm{mm}$ in diameter)

NON-PLASTICS AND PASTE: grog and bone

RIM AND LIP FORM: Direct rim and rounded lip

CORE COLOR: F (fired in a reducing environment and cooled in the open air)

INTERIOR SURFACE COLOR: yellowish-brown; fire clouds on the rim and body

EXTERIOR SURFACE COLOR: yellowishbrown; fire clouds on the rim, body, and base

WALL THICKNESS (IN MM): rim, $4.6 \mathrm{~mm}$

INTERIOR SURFACE TREATMENT: none

EXTERIOR SURFACE TREATMENT: none

HEIGHT (IN CM): 3.7

ORIFICE DIAMETER (IN CM): 11.4

DIAMETER AT BOTTOM OF RIM OR NECK (IN CM): N/A

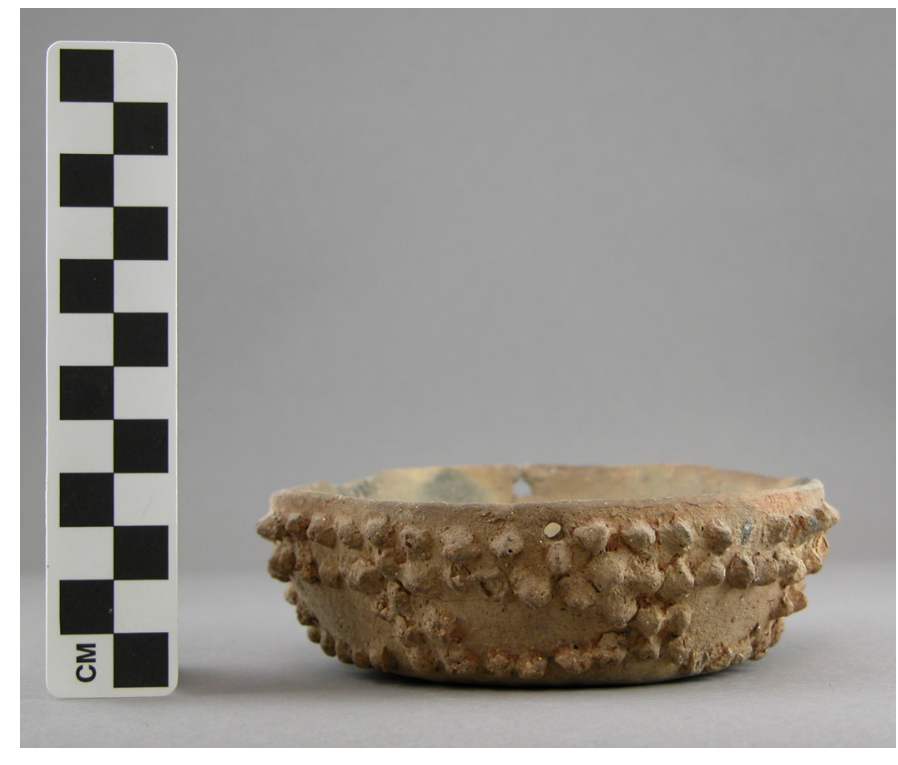

BASE DIAMETER (IN CM) AND SHAPE OF BASE: $8.2 \mathrm{~cm}$; circular and flat

ESTIMATED VOLUME (IN LITERS): 0.17
Figure 60. Moore Noded bowl (6-4-581) in Burial 2 in Village Plot 1 at the Hatchel site.

DECORATION (INCLUDING MOTIF AND ELEMENTS WHEN APPARENT): The vessel has two upper horizontal rows of small appliqued nodes and one lower row of appliqued nodes (Figure 60). The horizontal rows are connected by seven vertical appliqued node columns, with open areas between the horizontal and vertical rows of nodes.

PIGMENT USE AND LOCATION ON VESSEL: none

TYPE AND VARIETY (IF KNOWN): Moore Noded 
SITE NAME OR SITE NUMBER: Hatchel (41BW3)

VESSEL NO.: 6-4-582; Burial 2 in Village Plot 1

VESSEL FORM: Jar

NON-PLASTICS AND PASTE: grog and bone

RIM AND LIP FORM: Everted rim and rounded lip

CORE COLOR: F (fired in a reducing environment and cooled in the open air)

INTERIOR SURFACE COLOR: dark yellowish-brown; fire clouds on the rim and body

EXTERIOR SURFACE COLOR: dark yellowishbrown; fire clouds on the rim, body, and base

WALL THICKNESS (IN MM): rim, $5.5 \mathrm{~mm}$

INTERIOR SURFACE TREATMENT: smoothed

EXTERIOR SURFACE TREATMENT:

smoothed on the body

HEIGHT (IN CM): 10.8

ORIFICE DIAMETER (IN CM): 11.6

DIAMETER AT BOTTOM OF RIM OR NECK (IN CM): 11.0

BASE DIAMETER (IN CM) AND SHAPE OF

BASE: $6.4 \mathrm{~cm}$; circular and flat

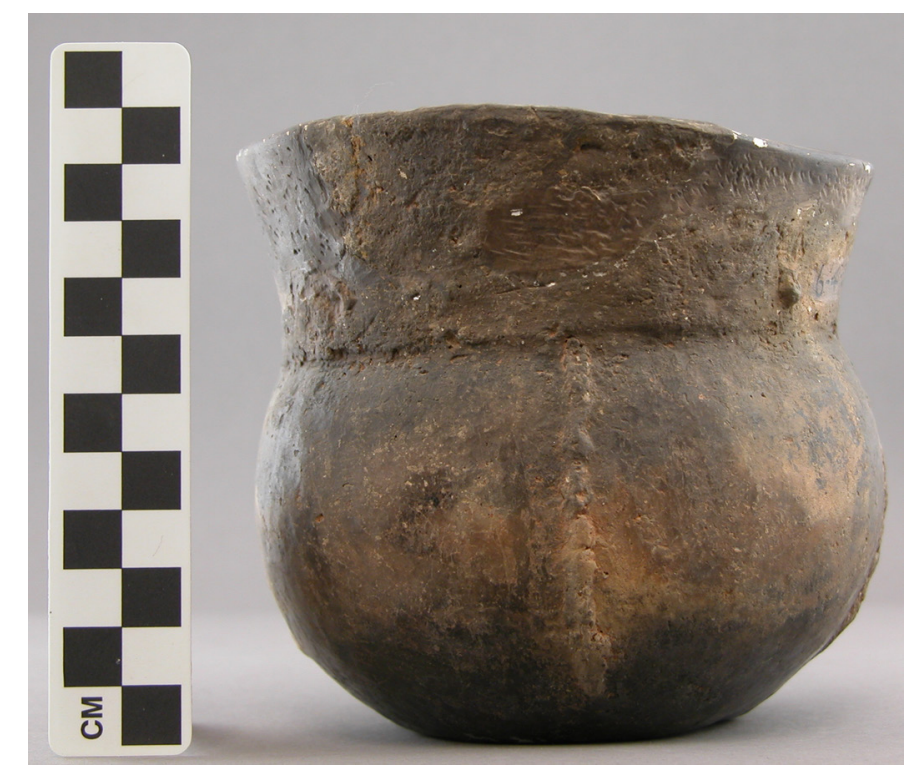

Figure 61. McKinney Plain jar (6-4-582) in Burial 2 in Village Plot 1 at the Hatchel site.

\section{ESTIMATED VOLUME (IN LITERS): 0.75}

DECORATION (INCLUDING MOTIF AND ELEMENTS WHEN APPARENT): The rim has two widely-spaced appliqued nodes ( $2.5 \mathrm{~mm}$ in diameter) between two vertical appliqued ridges. The vessel body has four vertical appliqued ridges (Figure 61).

PIGMENT USE AND LOCATION ON VESSEL: none

TYPE AND VARIETY (IF KNOWN): McKinney Plain 
SITE NAME OR SITE NUMBER: Hatchel (41BW3)

VESSEL NO.: 6-4-592; Feature 4 in Village Plot 2

VESSEL FORM: Jar

NON-PLASTICS AND PASTE: grog

RIM AND LIP FORM: Everted rim and rounded, exterior folded lip

CORE COLOR: $\mathrm{H}$ (fired in a reducing environment and cooled in the open air)

INTERIOR SURFACE COLOR: dark yellowish-brown; fire clouds on the rim and body

EXTERIOR SURFACE COLOR: dark yellowishbrown; fire clouds on the rim, body, and base

WALL THICKNESS (IN MM): rim, $5.6 \mathrm{~mm}$

INTERIOR SURFACE TREATMENT: smoothed

EXTERIOR SURFACE TREATMENT: none

HEIGHT (IN CM): 10.8

ORIFICE DIAMETER (IN CM): 12.6

DIAMETER AT BOTTOM OF RIM OR NECK (IN CM): 12.1

BASE DIAMETER (IN CM) AND SHAPE OF BASE: $6.4 \mathrm{~cm}$; circular and flat

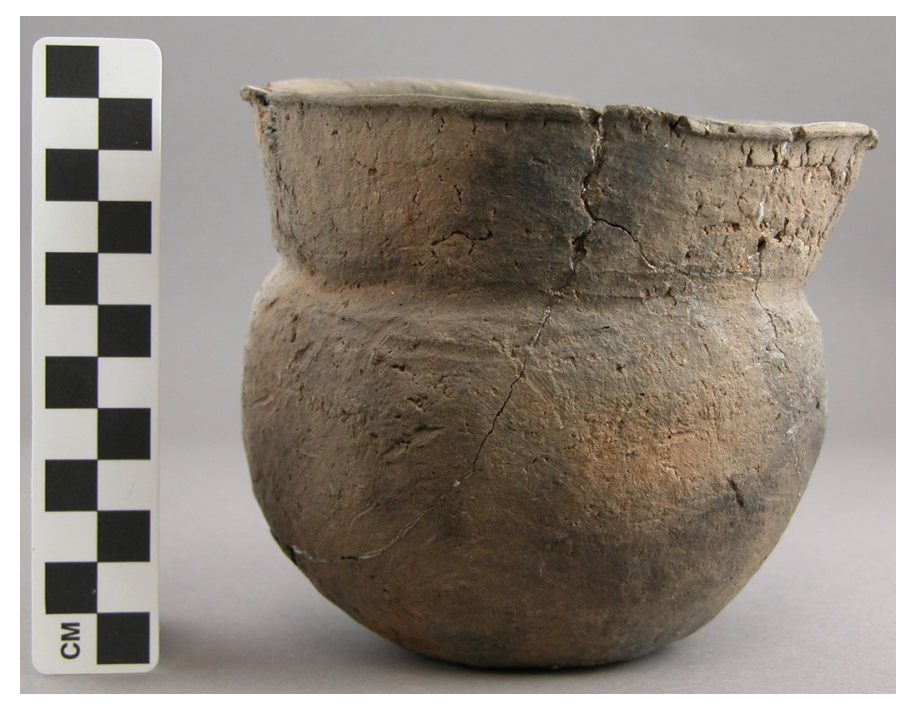

Figure 62. Incised jar (6-4-592) in Feature 4 in Village Plot 2 at the Hatchel site.

\section{ESTIMATED VOLUME (IN LITERS): 0.82}

DECORATION (INCLUDING MOTIF AND ELEMENTS WHEN APPARENT): The rim of the vessel is plain, but the body has $8+$ zig-zag incised lines around the vessel that extend from the mid-body to near the base (Figure 62).

PIGMENT USE AND LOCATION ON VESSEL: none

TYPE AND VARIETY (IF KNOWN): Unidentified utility ware 
SITE NAME OR SITE NUMBER: Hatchel (41BW3)

VESSEL NO.: 6-6-604; Burial 1 in Village Plot 2

VESSEL FORM: Bottle

NON-PLASTICS AND PASTE: grog

RIM AND LIP FORM: Direct rim and rounded, exterior flaring lip

CORE COLOR: F (fired in a reducing environment and cooled in the open air)

INTERIOR SURFACE COLOR: reddish-brown

EXTERIOR SURFACE COLOR: reddish-brown; fire clouds on the rim, body, and base

WALL THICKNESS (IN MM): rim, $5.3 \mathrm{~mm}$

INTERIOR SURFACE TREATMENT: none

EXTERIOR SURFACE TREATMENT:

smoothed

HEIGHT (IN CM): 13.5

ORIFICE DIAMETER (IN CM): 4.3

DIAMETER AT BOTTOM OF RIM OR NECK (IN CM): 4.3 ; maximum body diameter of $8.8 \mathrm{~cm}$

\section{BASE DIAMETER (IN CM) AND SHAPE OF}

BASE: $5.7 \mathrm{~cm}$; circular and flat

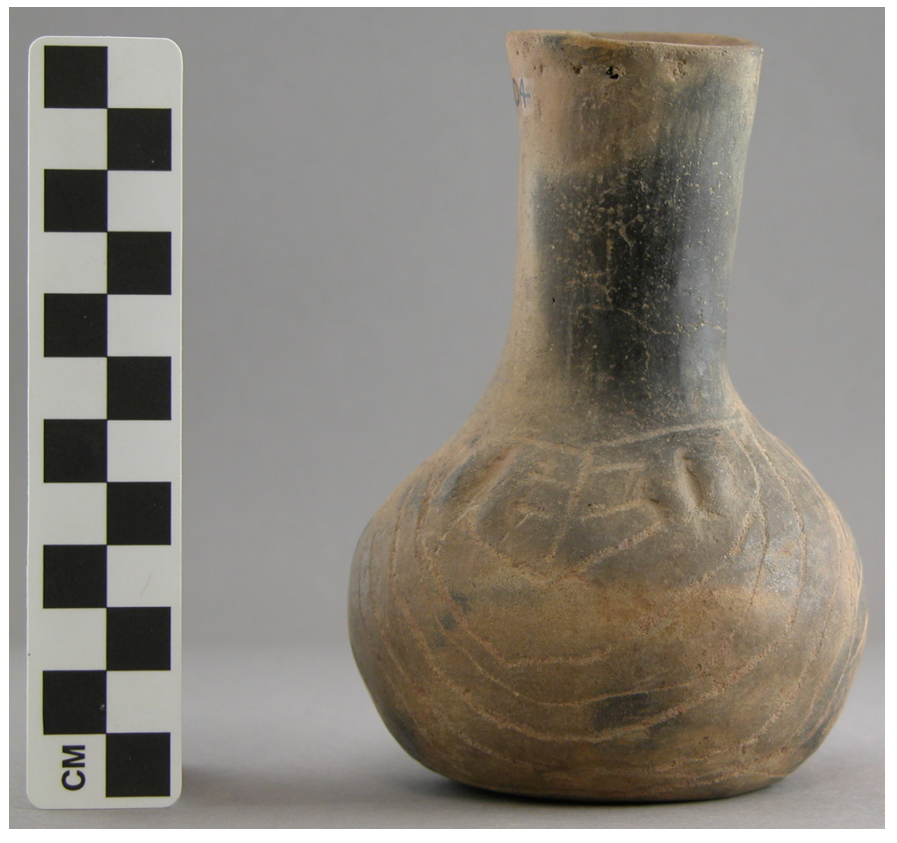

Figure 63. Hatchel Engraved bottle (6-6-604) in Burial 1 in Village Plot 2 at the Hatchel site.

\section{ESTIMATED VOLUME (IN LITERS): 0.31}

DECORATION (INCLUDING MOTIF AND ELEMENTS WHEN APPARENT): The vessel body has four engraved panels, including two with concentric semi-circles and the other two with diagonal and diagonal opposed lines (Figure 63). The innermost of the concentric semi-circles has diagonal opposed engraved lines and two side-by-side small appliqued ridges. There are also two small appliqued ridges at the top end of the diagonal engraved lines.

PIGMENT USE AND LOCATION ON VESSEL: none

TYPE AND VARIETY (IF KNOWN): Hatchel Engraved 
SITE NAME OR SITE NUMBER: Hatchel (41BW3)

VESSEL NO.: 6-6-605; Burial 1 in Village Plot 2

VESSEL FORM: Compound Bowl

NON-PLASTICS AND PASTE: grog

RIM AND LIP FORM: Everted rim and rounded, exterior folded lip

CORE COLOR: B (fired and cooled in a reducing environment)

INTERIOR SURFACE COLOR: very dark grayish-brown

EXTERIOR SURFACE COLOR: dark grayishbrown; fire clouds on the rim panels

WALL THICKNESS (IN MM): rim, $5.0 \mathrm{~mm}$

INTERIOR SURFACE TREATMENT: smoothed

EXTERIOR SURFACE TREATMENT: burnished

HEIGHT (IN CM): 8.2

ORIFICE DIAMETER (IN CM): 8.9

DIAMETER AT BOTTOM OF RIM OR NECK (IN CM): 8.4

BASE DIAMETER (IN CM) AND SHAPE OF BASE: $3.7 \mathrm{~cm}$; circular and flat

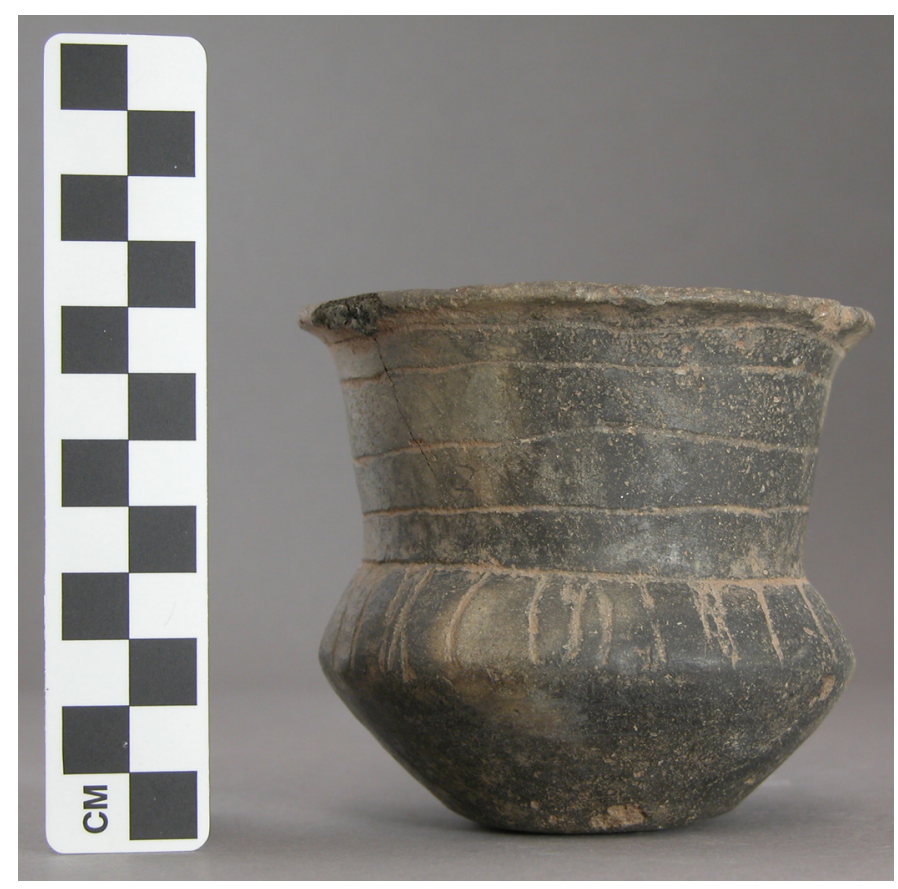

Figure 64. cf. Avery Engraved compound bowl (6-6605) in Burial 1 in Village Plot 2 at the Hatchel site.

\section{ESTIMATED VOLUME (IN LITERS): 0.58}

DECORATION (INCLUDING MOTIF AND ELEMENTS WHEN APPARENT): The upper rim panel has a series of five widely-spaced horizontal engraved lines (Figure 64). The lower panel has a series of four central engraved semi-circles or ovals with curvilinear and vertical lines, as well as open brackets, between the central elements (Figure 64).

PIGMENT USE AND LOCATION ON VESSEL: none

TYPE AND VARIETY (IF KNOWN): cf. Avery Engraved 
SITE NAME OR SITE NUMBER: Hatchel (41BW3)

VESSEL NO.: 6-6-606; Burial 1 in Village Plot 2

VESSEL FORM: Compound bowl with four lip tabs

NON-PLASTICS AND PASTE: grog

RIM AND LIP FORM: Everted rim and rounded lip

CORE COLOR: B (fired and cooled in a reducing environment)

INTERIOR SURFACE COLOR: dark grayishbrown; fire clouds on the rim

EXTERIOR SURFACE COLOR: dark grayishbrown; fire clouds on the rim

WALL THICKNESS (IN MM): rim, $4.5 \mathrm{~mm}$

INTERIOR SURFACE TREATMENT: smoothed

EXTERIOR SURFACE TREATMENT:

smoothed on the body

HEIGHT (IN CM): 6.4

ORIFICE DIAMETER (IN CM): 6.4

DIAMETER AT BOTTOM OF RIM OR NECK (IN CM): 6.0

BASE DIAMETER (IN CM) AND SHAPE OF

BASE: $3.3 \mathrm{~cm}$; circular and flat

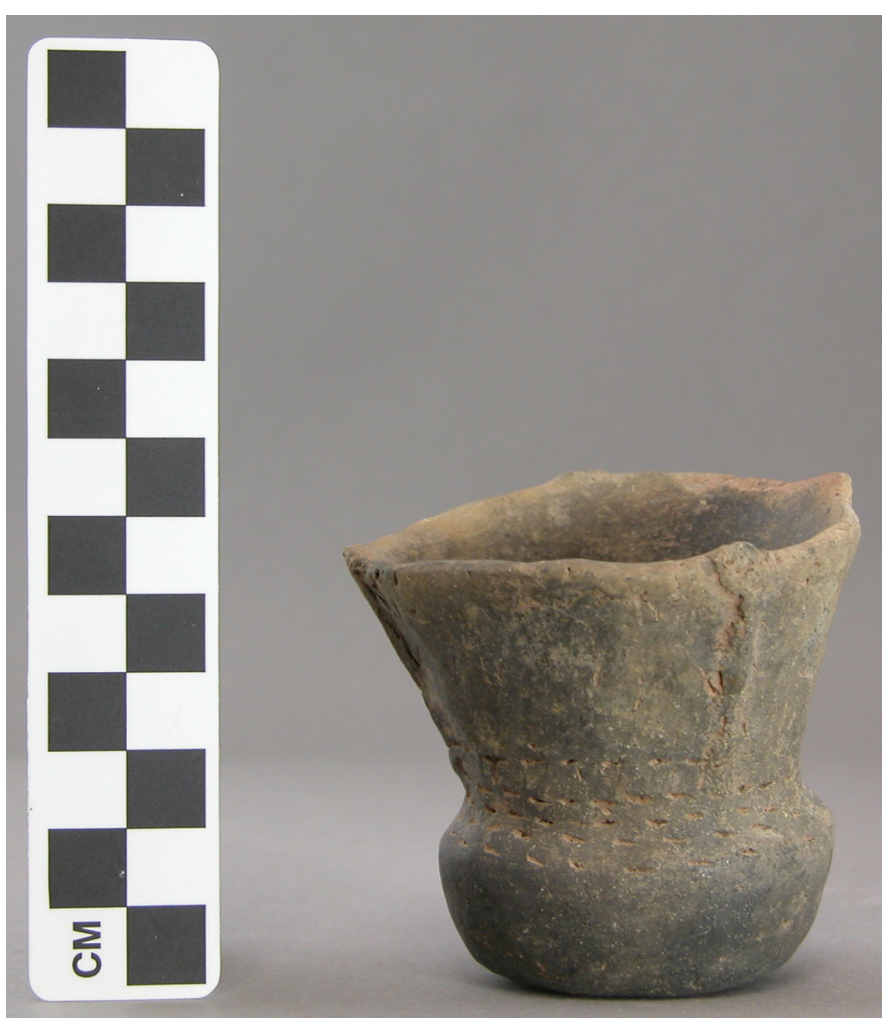

ESTIMATED VOLUME (IN LITERS): 0.33

Figure 65. Appliqued-punctated compound bowl (66-606) in Burial 1 in Village Plot 2 at the Hatchel site.

DECORATION (INCLUDING MOTIF AND ELEMENTS WHEN APPARENT): The upper panel of the vessel has four vertical appliqued ridges as well as two horizontal rows of tool punctations at the base of the panel (Figure 65). The lower panel has three horizontal rows of tool punctations.

PIGMENT USE AND LOCATION ON VESSEL: none

TYPE AND VARIETY (IF KNOWN): Unidentified utility ware 
SITE NAME OR SITE NUMBER: Hatchel (41BW3)

VESSEL NO.: 6-6-607; Burial 2 in Village Plot 2

VESSEL FORM: Carinated bowl

NON-PLASTICS AND PASTE: grog

RIM AND LIP FORM: Inverted rim and rounded lip

CORE COLOR: B (fired and cooled in a reducing environment)

INTERIOR SURFACE COLOR: very dark grayish-brown

EXTERIOR SURFACE COLOR: very dark grayish-brown; fire clouds on the body and base

WALL THICKNESS (IN MM): rim, $4.0 \mathrm{~mm}$

INTERIOR SURFACE TREATMENT: burnished on the rim; smoothed on the body

EXTERIOR SURFACE TREATMENT: burnished

HEIGHT (IN CM): 7.1

ORIFICE DIAMETER (IN CM): 14.0

DIAMETER AT BOTTOM OF RIM OR NECK (IN CM): 15.3

BASE DIAMETER (IN CM) AND SHAPE OF BASE: $5.1 \mathrm{~cm}$; circular and rounded

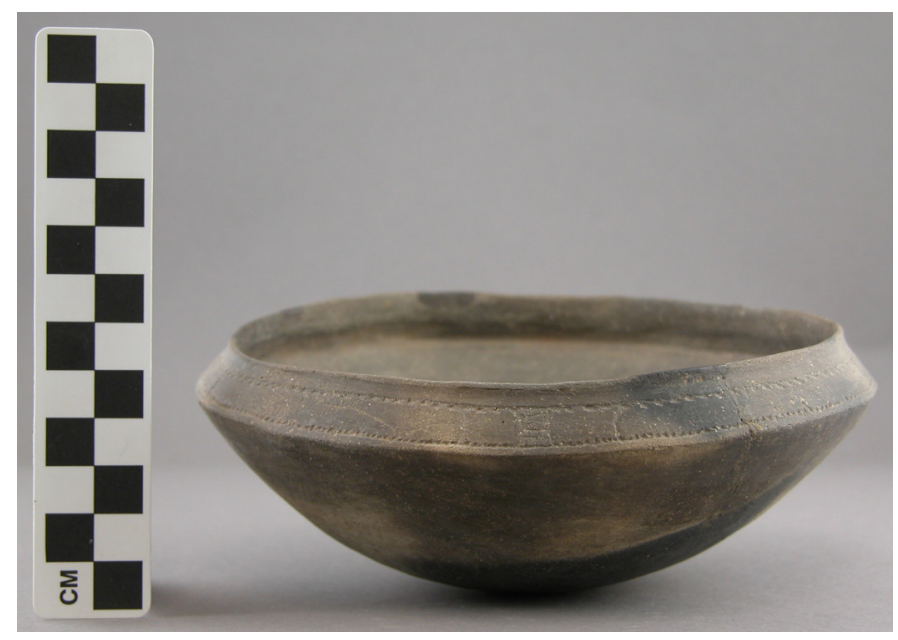

Figure 66. Simms Engraved carinated bowl (6-6-607) in Burial 2 in Village Plot 2 at the Hatchel site.

\section{ESTIMATED VOLUME (IN LITERS): 0.6}

DECORATION (INCLUDING MOTIF AND ELEMENTS WHEN APPARENT): The rim is divided into four rectangular panels by cross-hatched engraved brackets; there are single horizontal engraved lines at the top and bottom of the panel (Figure 66). There are also single curvilinear to vertical engraved lines on either side of the cross-hatched engraved brackets, and the upper and lower horizontal engraved lines have excised tick marks that either point downwards or upwards on the lines (Figure 66).

PIGMENT USE AND LOCATION ON VESSEL: none

TYPE AND VARIETY (IF KNOWN): Simms Engraved 
SITE NAME OR SITE NUMBER: Hatchel (41BW3)

VESSEL NO.: 6-6-608; Burial 2 in Village Plot 2

VESSEL FORM: Carinated bowl

NON-PLASTICS AND PASTE: grog

RIM AND LIP FORM: Inverted-direct rim and rounded lip

CORE COLOR: F (fired in a reducing environment and cooled in the open air)

INTERIOR SURFACE COLOR: dark yellowish-brown; fire clouds on the body and base

EXTERIOR SURFACE COLOR: dark yellowishbrown; fire clouds on the rim, body, and base

WALL THICKNESS (IN MM): rim, $4.0 \mathrm{~mm}$

INTERIOR SURFACE TREATMENT: smoothed

EXTERIOR SURFACE TREATMENT:

smoothed

HEIGHT (IN CM): 5.7

ORIFICE DIAMETER (IN CM): 8.9

DIAMETER AT BOTTOM OF RIM OR NECK (IN CM): 9.8

BASE DIAMETER (IN CM) AND SHAPE OF

BASE: $3.7 \mathrm{~cm}$; circular and flat

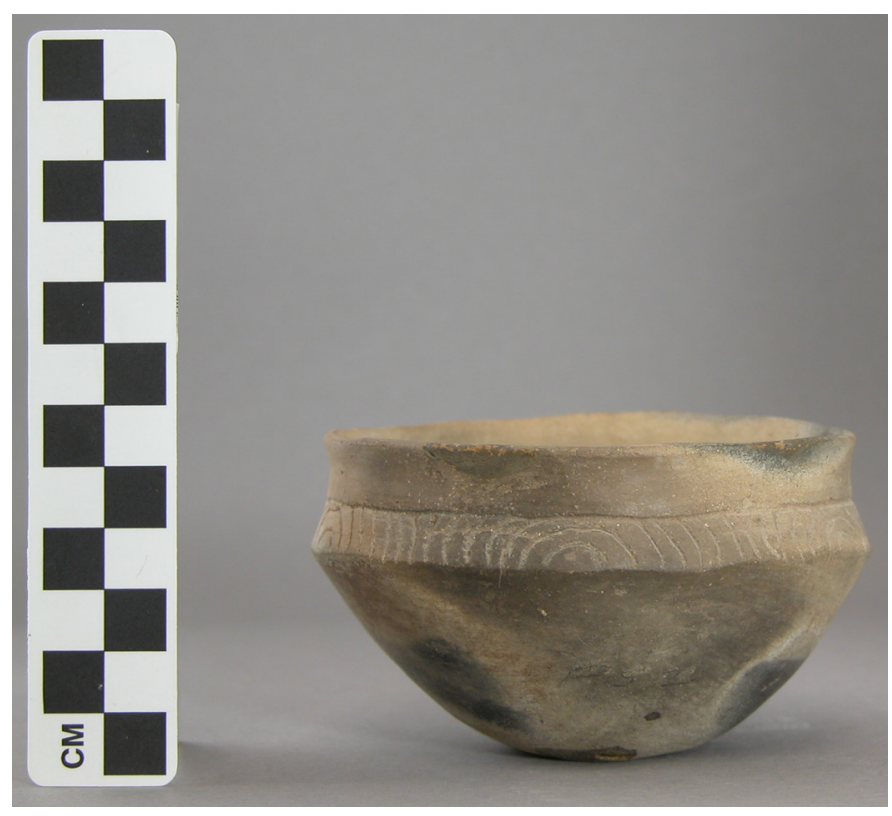

Figure 67. Avery Engraved, var. Graves carinated bowl in Burial 2 in Village Plot 2 at the Hatchel site.

ESTIMATED VOLUME (IN LITERS): 0.31

DECORATION (INCLUDING MOTIF AND ELEMENTS WHEN APPARENT): The rim is divided into two parts by a single horizontal engraved line mid-rim. Below the horizontal line are a series of six engraved nested concentric semi-circles (Figure 67). The rim is plain above the single mid-rim horizontal engraved line.

PIGMENT USE AND LOCATION ON VESSEL: none

TYPE AND VARIETY (IF KNOWN): Avery Engraved, var. Graves (see Schambach and Miller 1984:119). 
SITE NAME OR SITE NUMBER: Hatchel (41BW3)

VESSEL NO.: 6-6-609; Burial 2 in Village Plot 2

VESSEL FORM: Bottle

NON-PLASTICS AND PASTE: shell

RIM AND LIP FORM: Direct rim and rounded, exterior folded lip

CORE COLOR: B (fired and cooled in a reducing environment)

INTERIOR SURFACE COLOR: black

EXTERIOR SURFACE COLOR: black; fire clouds on the body

WALL THICKNESS (IN MM): rim, $4.8 \mathrm{~mm}$

INTERIOR SURFACE TREATMENT: none

EXTERIOR SURFACE TREATMENT: burnished

HEIGHT (IN CM): 14.6

ORIFICE DIAMETER (IN CM): 5.2

DIAMETER AT BOTTOM OF RIM OR NECK

(IN CM): 4.4

BASE DIAMETER (IN CM) AND SHAPE OF BASE: $5.8 \mathrm{~cm}$; circular and concave

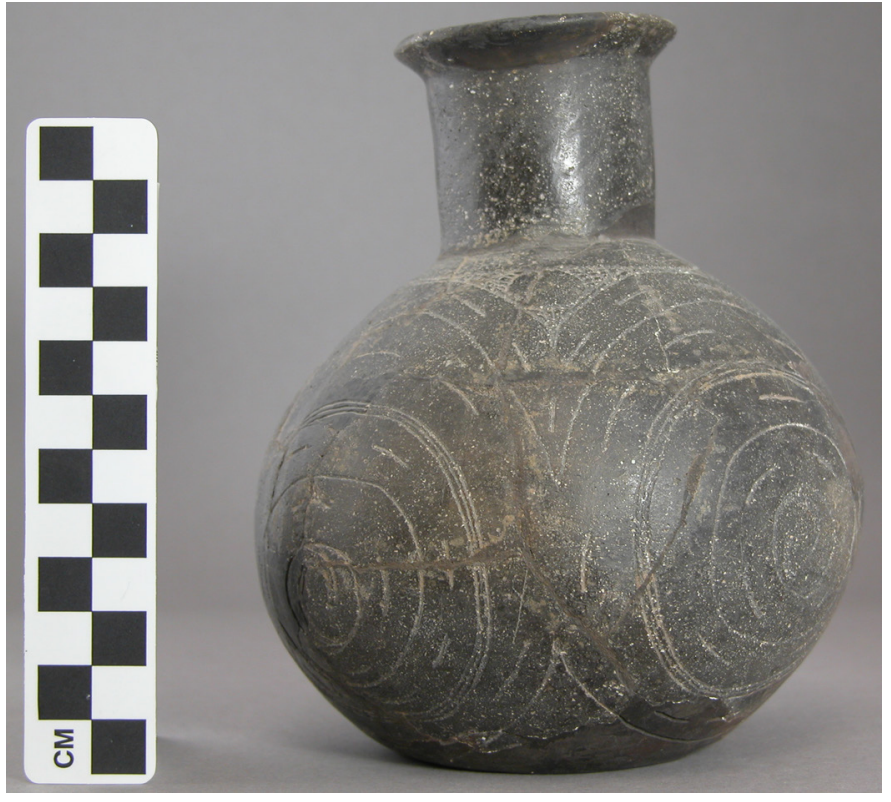

Figure 68. Belcher Engraved, var. Ogden bottle (6-6609) in Burial 2 in Village Plot 2 at the Hatchel site.

\section{ESTIMATED VOLUME (IN LITERS): 0.34}

DECORATION (INCLUDING MOTIF AND ELEMENTS WHEN APPARENT): The vessel body is decorated with four sets of engraved concentric circles that alternate with concentric dashed lines (Figure 68). The innermost circle has opposed curvilinear hooked arm elements. There are four large engraved pendant triangles between the sets of concentric circles. The pendant triangles have within them a single negative circle outlined by cross-hatched engraved zones at the apexes of the triangles (Figure 68)

PIGMENT USE AND LOCATION ON VESSEL: none

TYPE AND VARIETY (IF KNOWN): Belcher Engraved, var. Ogden 
SITE NAME OR SITE NUMBER: Hatchel (41BW3)

VESSEL NO.: 6-6-610; Burial 2 in Village Plot 2

VESSEL FORM: Jar

NON-PLASTICS AND PASTE: grog

RIM AND LIP FORM: Everted rim and rounded lip

CORE COLOR: B (fired and cooled in a reducing environment)

INTERIOR SURFACE COLOR: very dark grayish-brown

EXTERIOR SURFACE COLOR: dark grayishbrown; fire clouds on the body

WALL THICKNESS (IN MM): rim, $7.1 \mathrm{~mm}$

INTERIOR SURFACE TREATMENT: smoothed

EXTERIOR SURFACE TREATMENT:

smoothed on the body

HEIGHT (IN CM): 14.0

ORIFICE DIAMETER (IN CM): 15.2

DIAMETER AT BOTTOM OF RIM OR NECK (IN CM): 13.2

BASE DIAMETER (IN CM) AND SHAPE OF

BASE: $5.1 \mathrm{~cm}$; circular and flat

ESTIMATED VOLUME (IN LITERS): 1.3

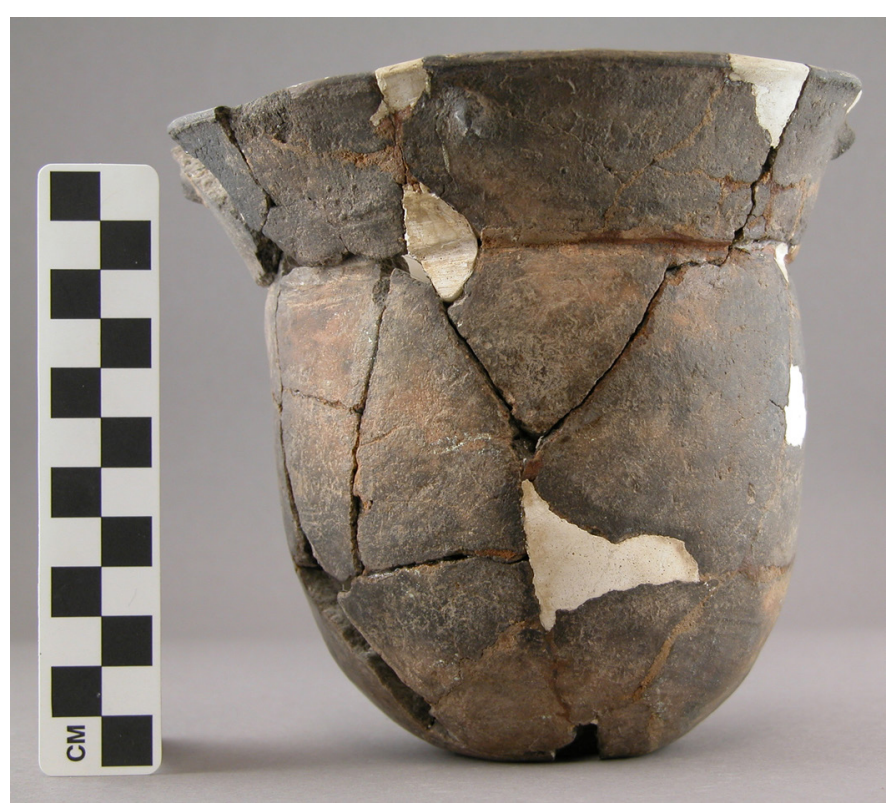

Figure 69. McKinney Plain jar (6-6-610) in Burial 2 in Village Plot 2 at the Hatchel site.

DECORATION (INCLUDING MOTIF AND ELEMENTS WHEN APPARENT): The vessel is decorated with four large (4.6 $\mathrm{mm}$ in diameter) appliqued nodes spaced around the rim and below the lip (Figure 69).

PIGMENT USE AND LOCATION ON VESSEL: none

TYPE AND VARIETY (IF KNOWN): McKinney Plain 
SITE NAME OR SITE NUMBER: Hatchel (41BW3)

VESSEL NO.: 6-6-611; Burial 2 in Village Plot 2

VESSEL FORM: Bowl

NON-PLASTICS AND PASTE: grog

RIM AND LIP FORM: Direct rim and rounded lip

CORE COLOR: F (fired in a reducing environment and cooled in the open air)

INTERIOR SURFACE COLOR: light grayishbrown

EXTERIOR SURFACE COLOR: reddish-brown

WALL THICKNESS (IN MM): rim, $5.3 \mathrm{~mm}$

INTERIOR SURFACE TREATMENT: none

EXTERIOR SURFACE TREATMENT:

smoothed

HEIGHT (IN CM): 5.1

ORIFICE DIAMETER (IN CM): 7.6

DIAMETER AT BOTTOM OF RIM OR NECK (IN CM): N/A

BASE DIAMETER (IN CM) AND SHAPE OF BASE: $5.1 \mathrm{~cm}$; circular and flat

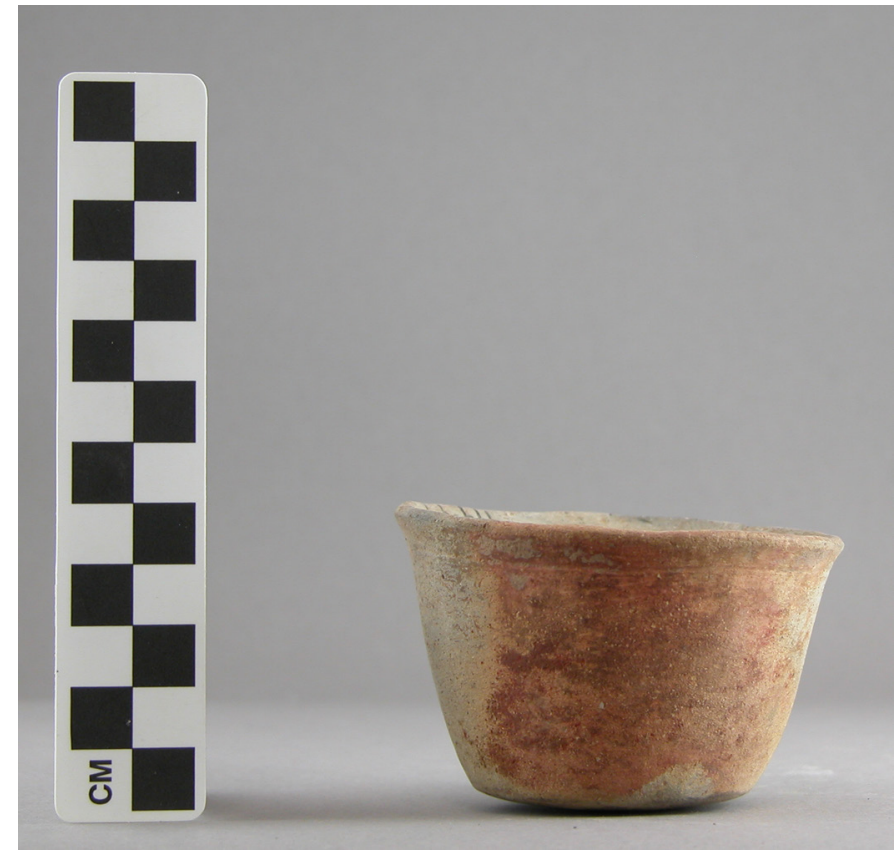

Figure 70. Incised bowl (6-6-611) in Burial 2 in Village Plot 2 at the Hatchel site.

\section{ESTIMATED VOLUME (IN LITERS): 0.16}

DECORATION (INCLUDING MOTIF AND ELEMENTS WHEN APPARENT): There is a single horizontal incised line below the vessel lip (Figure 70).

PIGMENT USE AND LOCATION ON VESSEL: none

TYPE AND VARIETY (IF KNOWN): Unidentified utility ware 
SITE NAME OR SITE NUMBER: Hatchel (41BW3)

VESSEL NO.: 6-6-621; Burial 3 in Village Plot 2

VESSEL FORM: Bottle

NON-PLASTICS AND PASTE: grog

RIM AND LIP FORM: N/A

CORE COLOR: F (fired in a reducing environment and cooled in the open air)

INTERIOR SURFACE COLOR: yellowish-brown

EXTERIOR SURFACE COLOR: yellowishbrown; fire clouds on the rim, body, and base

WALL THICKNESS (IN MM): rim, $6.7 \mathrm{~mm}$

INTERIOR SURFACE TREATMENT: none

EXTERIOR SURFACE TREATMENT:

smoothed

HEIGHT (IN CM): 12.7+

ORIFICE DIAMETER (IN CM): 3.7

DIAMETER AT BOTTOM OF RIM OR NECK (IN CM): 4.8

BASE DIAMETER (IN CM) AND SHAPE OF BASE: $7.7 \mathrm{~cm}$; circular and flat

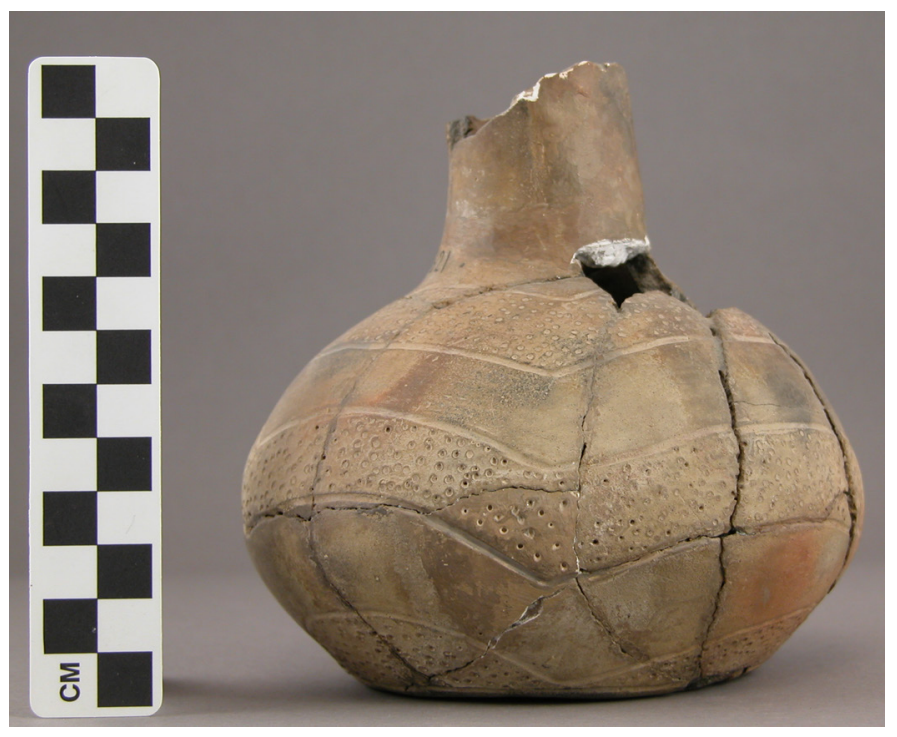

Figure 71. Trailed-punctated bottle (6-6-621) in Burial 3 in Village Plot 2 at the Hatchel site.

ESTIMATED VOLUME (IN LITERS): 0.39+

DECORATION (INCLUDING MOTIF AND ELEMENTS WHEN APPARENT): The vessel body has upper diagonal and curvilinear zones filled with small circular punctations that are repeated four times around the vessel, as well as four semi-circular trailed zones filled with small circular punctations (Figure 71).

PIGMENT USE AND LOCATION ON VESSEL: none

TYPE AND VARIETY (IF KNOWN): Unidentified fine ware 
SITE NAME OR SITE NUMBER: Hatchel (41BW3)

VESSEL NO.: 6-6-622; Burial 3 in Village Plot 2

VESSEL FORM: Jar

NON-PLASTICS AND PASTE: grog and bone

RIM AND LIP FORM: Everted rim and rounded lip

CORE COLOR: B (fired and cooled in a reducing environment)

INTERIOR SURFACE COLOR: very dark grayish-brown

EXTERIOR SURFACE COLOR: very dark grayish-brown; fire clouds on the rim, body, and base

WALL THICKNESS (IN MM): rim, $5.0 \mathrm{~mm}$

INTERIOR SURFACE TREATMENT: smoothed on the rim

EXTERIOR SURFACE TREATMENT: smoothed on the body

HEIGHT (IN CM): 7.0

ORIFICE DIAMETER (IN CM): 7.6

DIAMETER AT BOTTOM OF RIM OR NECK (IN CM): 5.7

BASE DIAMETER (IN CM) AND SHAPE OF BASE: $4.3 \mathrm{~cm}$; circular and rounded

ESTIMATED VOLUME (IN LITERS): 0.32

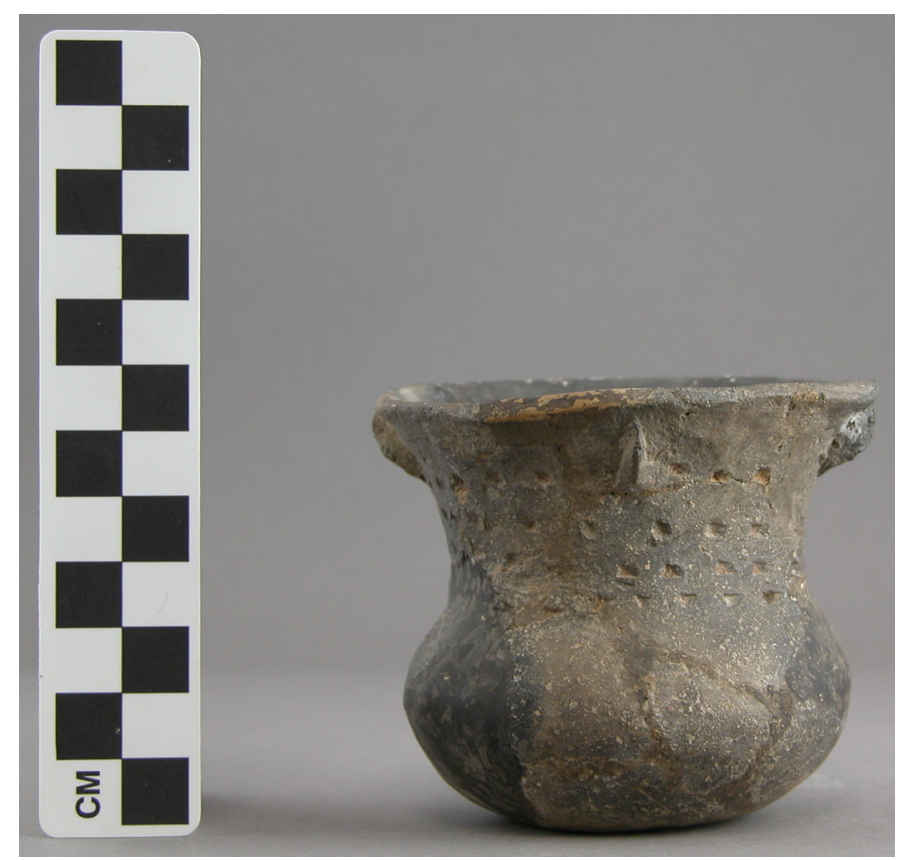

Figure 72. Punctated-appliqued jar (6-6-622) in Burial 3 in Village Plot 2 at the Hatchel site.

DECORATION (INCLUDING MOTIF AND ELEMENTS WHEN APPARENT): There are four appliqued lugs on the rim below the vessel lip, as well as four horizontal rows of tool punctations that begin immediately below the bottom of the appliqued lugs (Figure 72).

PIGMENT USE AND LOCATION ON VESSEL: none

TYPE AND VARIETY (IF KNOWN): Unidentified utility ware 
SITE NAME OR SITE NUMBER: Hatchel (41BW3)

VESSEL NO.: 6-6-623; Burial 3 in Village Plot 2

VESSEL FORM: Jar with four lip tabs

NON-PLASTICS AND PASTE: grog

RIM AND LIP FORM: Everted rim and rounded lip

CORE COLOR: B (fired and cooled in a reducing environment)

INTERIOR SURFACE COLOR: very dark grayish-brown

EXTERIOR SURFACE COLOR: very dark grayish-brown; fire clouds on the rim, body, and base

WALL THICKNESS (IN MM): rim, 8.4 mm

INTERIOR SURFACE TREATMENT: smoothed

EXTERIOR SURFACE TREATMENT:

smoothed on the body

HEIGHT (IN CM): 10.5

ORIFICE DIAMETER (IN CM): 10.8

DIAMETER AT BOTTOM OF RIM OR NECK (IN CM): 9.5

BASE DIAMETER (IN CM) AND SHAPE OF

BASE: $4.8 \mathrm{~cm}$; circular and concave

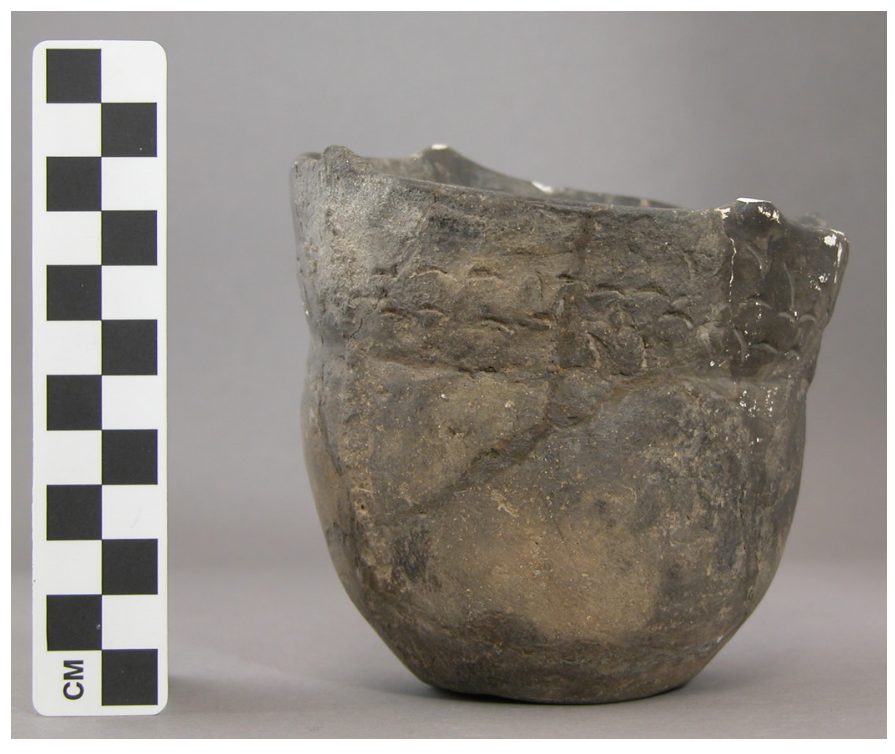

Figure 73. Appliqued-punctated jar (6-6-623) in Burial 3 in Village Plot 2 at the Hatchel site.

\section{ESTIMATED VOLUME (IN LITERS): 0.68}

DECORATION (INCLUDING MOTIF AND ELEMENTS WHEN APPARENT): The rim is decorated with three horizontal rows of fingernail punctations. The vessel body has four vertical appliqued ridges that begin on the body below the place of the lip tabs and extend to the vessel base (Figure 73).

PIGMENT USE AND LOCATION ON VESSEL: none

TYPE AND VARIETY (IF KNOWN): Unidentified utility ware 
SITE NAME OR SITE NUMBER: Hatchel (41BW3)

VESSEL NO.: 6-6-625; Burial 7 in Village Plot 2

VESSEL FORM: Carinated bowl

NON-PLASTICS AND PASTE: grog

RIM AND LIP FORM: Inverted rim and rounded lip

CORE COLOR: F (fired in a reducing environment and cooled in the open air)

INTERIOR SURFACE COLOR: dark yellowish-brown; fire clouds on the rim

EXTERIOR SURFACE COLOR: dark yellowish-brown; fire clouds on the rim and body

WALL THICKNESS (IN MM): rim, $5.6 \mathrm{~mm}$

INTERIOR SURFACE TREATMENT:

smoothed

EXTERIOR SURFACE TREATMENT:

smoothed

HEIGHT (IN CM): 6.4

ORIFICE DIAMETER (IN CM): 9.0

DIAMETER AT BOTTOM OF RIM OR NECK (IN CM): 8.7

BASE DIAMETER (IN CM) AND SHAPE OF BASE: $5.1 \mathrm{~cm}$; circular and flat

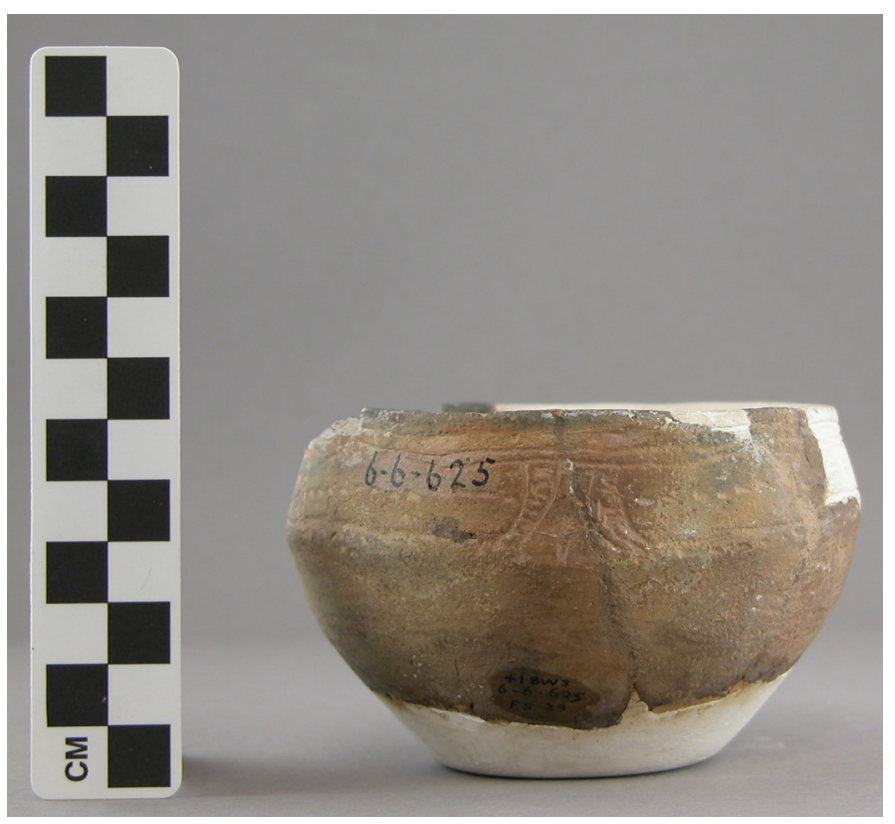

Figure 74. Barkman Engraved carinated bowl (6-6625) in Burial 7 in Village Plot 2 at the Hatchel site.

ESTIMATED VOLUME (IN LITERS): 0.35

DECORATION (INCLUDING MOTIF AND ELEMENTS WHEN APPARENT): The upper part of the rim has three closely-spaced horizontal engraved lines above a horizontal plan divided into four sections by two opposed curvilinear zones filled with excised punctations and a single row of vertical excised punctations (Figure 74). Inside the curvilinear zones is a single row of excised tool punctations, and there is another row of excised punctations below the curvilinear zones and immediately above the vessel carination (Figure 74).

PIGMENT USE AND LOCATION ON VESSEL: none

TYPE AND VARIETY (IF KNOWN): Barkman Engraved 
SITE NAME OR SITE NUMBER: Hatchel (41BW3)

VESSEL NO.: 6-6-626; Burial 9 in Village Plot 2

VESSEL FORM: Bowl

RIM AND LIP FORM: direct rim and rounded lip

CORE COLOR: F (fired in a reducing environment and cooled in the open air)

INTERIOR SURFACE COLOR: brown; fire clouds on the rim and body

EXTERIOR SURFACE COLOR: light brown; fire clouds on the rim, body, and base

WALL THICKNESS: rim, $5.6 \mathrm{~mm}$

INTERIOR SURFACE TREATMENT: smoothed

EXTERIOR SURFACE TREATMENT:

smoothed

HEIGHT: $8.5 ; 9.0 \mathrm{~cm}$ at the lip tab

ORIFICE DIAMETER: 14.5

DIAMETER AT BOTTOM OF RIM OR NECK: N/A

BASE DIAMETER AND SHAPE: 6.6; circular and flat

ESTIMATED VOLUME: 0.49 liters

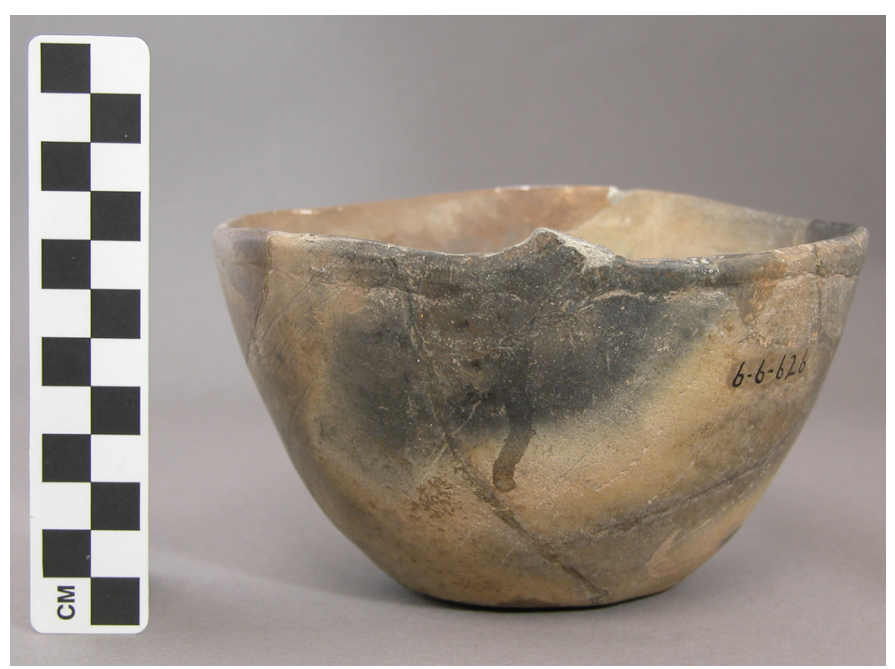

Figure 75. Plain effigy bowl (6-6-626) with a tab tail attachment from Burial 9 in Village Plot 2 at the Hatchel site (41BW3).

DECORATION: Plain. The vessel has a lip tab at one end that is $21 \times 8 \mathrm{~mm}$ in width and height. There is no evidence of an effigy head attachment (Figure 75).

PIGMENT: none

TYPE: Unidentified plain ware 
SITE NAME OR SITE NUMBER: Hatchel (41BW3)

VESSEL NO.: 6-6-630; Burial 10 in Village Plot 2

VESSEL FORM: Carinated bowl

NON-PLASTICS AND PASTE: grog

RIM AND LIP FORM: Inverted rim and rounded lip

CORE COLOR: $\mathrm{G}$ (fired in a reducing environment and cooled in the open air)

INTERIOR SURFACE COLOR: dark grayish-brown

EXTERIOR SURFACE COLOR: dark yellowish-brown

WALL THICKNESS (IN MM): rim, $5.3 \mathrm{~mm}$

INTERIOR SURFACE TREATMENT: none

EXTERIOR SURFACE TREATMENT:

smoothed

HEIGHT (IN CM): 6.4

ORIFICE DIAMETER (IN CM): 7.6

DIAMETER AT BOTTOM OF RIM OR NECK (IN CM): 7.0

BASE DIAMETER (IN CM) AND SHAPE OF BASE: $5.7 \mathrm{~cm}$; circular and flat

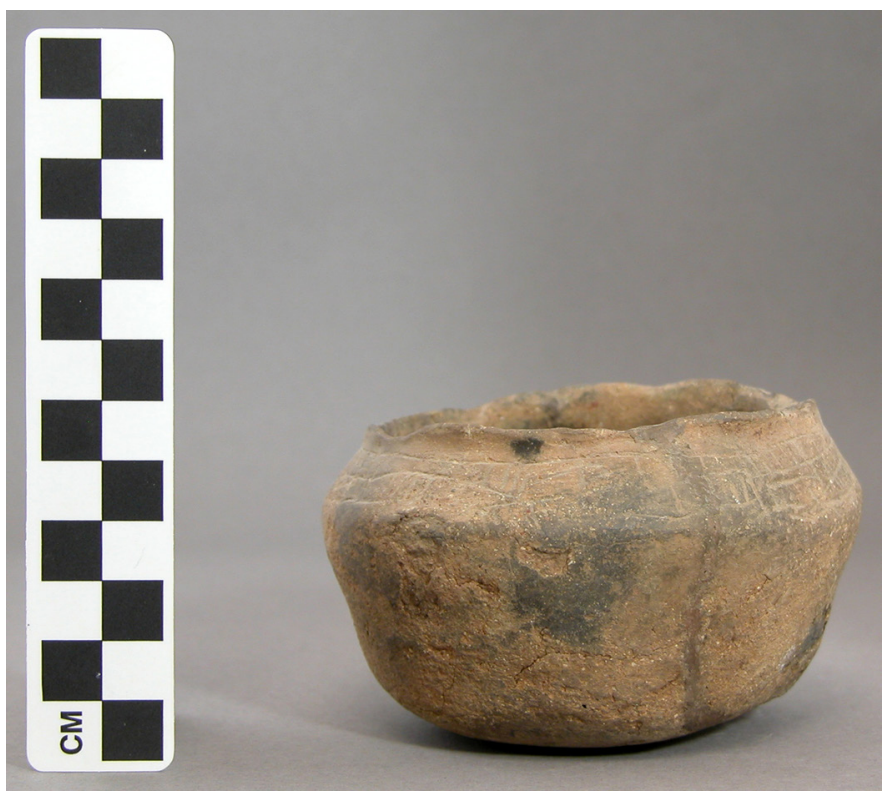

Figure 76. Engraved carinated bowl (6-6-630) in Burial 10 in Village Plot 2 at the Hatchel site.

ESTIMATED VOLUME (IN LITERS): 0.3

DECORATION (INCLUDING MOTIF AND ELEMENTS WHEN APPARENT): The rim is decorated with four sets of stacked diagonal engraved zones filled with vertical engraved lines (Figure 76).

PIGMENT USE AND LOCATION ON VESSEL: none

TYPE AND VARIETY (IF KNOWN): Unidentified fine ware 


\section{Summary and Conclusions}

There are a total of 68 ancestral Caddo ceramic vessels in the TARL collections from the Hatchel site (41BW3), a large and preeminent Caddo mound center and village on an old channel of the Red River in northeastern Bowie County in East Texas. These vessels were recovered during 1938-1939 WPA excavations at the site (Jackson 2003, 2004; Perttula 2005, 2014a).

The vessels are from excavations in several village areas $(n=19)$ north-northwest and south (most notably in Village Plot 2) of the large platform mound at the site, in burial plot excavations ( $\mathrm{n}=23$ ) generally east of the platform mound (especially Burial Plots 1 and 2), and in burial features and non-burial structural features $(n=26)$ in (particularly in Zones $F$ and $H)$ or under the platform mound. Only three of the vessels from the WPA excavations are from pre-A.D. 1200 Early Caddo period contexts, while the remaining 95 percent are from post-ca. A.D. 1400/1500 Texarkana phase contexts in the platform mound (Zone I and above), village plot excavations, and the burial plots. None of the vessels from the Hatchel site in the TARL collections can be clearly associated with post-A.D. 1685 historic ceramic types or historic Caddo burials or structural features., except perhaps by a shell-tempered Keno Trailed, var. Glendora bottle in Burial 2 in Burial Plot 1.

The pre-A.D. 1200 ceramic vessels from the Hatchel site include a Crockett Curvilinear Incised carinated bowl from Zone K (the natural ground surface) under the constructed platform mound, and a Hickory Engraved bottle and a Crockett Curvilinear Incised bowl in Burial 14 in Burial Plot 1. The three vessels are grog-tempered, and fired in either an oxidizing (33 percent) or reducing (67 percent) environment. Excavations in several village areas south of the platform mound-as well as radiocarbon dates from features - indicate that there are preserved pre-A.D. 1200 Caddo occupational deposits at the Hatchel site (see Perttula 2005; Perttula and Nelson 2003).

In the village areas, burial plots, and platform mound contexts of Texarkana phase age, there is little difference in the proportion of the various wares, except that fine wares are proportionally most common in the burial plots and platform mound features (Table 1), and utility ware vessels are proportionally more common in village area features. Plain wares comprise only between 9.5-12.0 percent of the vessels from the Hatchel site, compared to 36.9 percent that are utility ware vessels and 52.3 percent that are fine ware vessels.

Table 1. Texarkana phase ceramic wares at the Hatchel site.

\begin{tabular}{lcccr}
\hline Ware & Village & Burial Plots & Platform Mound & N \\
\hline Plain & $10.5^{*}$ & 9.5 & 12.0 & 7 \\
Utility & 42.1 & 38.1 & 32.0 & 24 \\
Fine & 47.4 & 52.4 & 56.0 & 34 \\
\hline Totals & 19 & 21 & 25 & 65 \\
\hline
\end{tabular}

*percentage

There are six different ceramic vessel forms in the Hatchel site vessel assemblage (Table 2). Jars of various sizes are the most common, especially in Burial Plot features (52 percent), and are least common in village area features (31.6 percent). Overall, jars comprise 43 percent of the vessels from the site. Carinated bowls account for 29.2 percent of the vessel assemblage, and occur most commonly in the Burial 
Plot features and the platform mound. Bowls (10.8 percent) and bottles (10.8 percent) are equally common in burial and structural features across the site, and are particularly abundant in village area excavations. Compound bowls (6.2 percent) are also notably common in the village area excavations. The one olla is from Zone $\mathrm{H}$ in the platform mound.

Table 2. Texarkana phase ceramic vessel forms at the Hatchel site.

\begin{tabular}{lcccr}
\hline Form & Village & Burial Plots & Platform Mound & N \\
\hline Jar & 6 & 11 & 11 & 28 \\
Bowl & 3 & 1 & 3 & 7 \\
Carinated Bowl & 4 & 7 & 8 & 19 \\
Compound Bowl & 3 & - & 1 & 4 \\
Bottle & 4 & 2 & 1 & 7 \\
Olla & - & - & 25 & 65 \\
\hline Totals & 19 & 21 & 1 \\
\hline
\end{tabular}

There are a number of defined utility ware and fine ware ceramic types (see Suhm and Jelks 1962) represented in the Texarkana phase vessels from the Hatchel site (Table 3); a significant percentage (30 percent) of the vessels cannot be typologically identified. The most common utility ware vessels include McKinney Plain and Foster Trailed-Incised (found only in features in the platform mound), with lesser amounts of Nash Neck Banded, Karnack Brushed-Incised, and Moore Noded types.

Table 3. Ceramic types identified in Texarkana phase contexts at the Hatchel site.

\begin{tabular}{|c|c|c|c|c|}
\hline Type & Village & $\begin{array}{c}\text { Burial Plot } \\
\text { Mound }\end{array}$ & Platform & $\mathrm{N}$ \\
\hline \multicolumn{5}{|l|}{ Utility Ware } \\
\hline Foster Trailed-Incised & - & - & 3 & 3 \\
\hline Karnack Brushed-Incised & - & - & 1 & 1 \\
\hline McKinney Plain & 2 & 1 & 1 & 4 \\
\hline Moore Noded & 1 & - & - & 1 \\
\hline Nash Neck Banded & - & 2 & - & 2 \\
\hline \multicolumn{5}{|l|}{ Fine Ware } \\
\hline Avery Engraved & 2 & - & 2 & 4 \\
\hline Barkman Engraved & 1 & 4 & 3 & 8 \\
\hline Belcher Engraved & 1 & - & 2 & 3 \\
\hline Hatchel Engraved & 2 & 1 & - & 3 \\
\hline Hodges Engraved & - & 1 & 1 & 2 \\
\hline Keno Trailed & - & 1 & 1 & 2 \\
\hline Simms Engraved & 1 & 2 & 2 & 5 \\
\hline Totals & 10 & 12 & 16 & 38 \\
\hline
\end{tabular}


In the case of the fine wares, Barkman Engraved and Simms Engraved are the most common identified types, followed by several different Avery Engraved vessel forms (see Table 3); Barkman Engraved and Simms Engraved vessels are present in each of the WPA excavation areas. Less common fine wares include Belcher Engraved, Hatchel Engraved, Hodges Engraved, and Keno Trailed; the Hodges Engraved and Keno Trailed vessels, both post-A.D. 1600 in age, are present only in the Burial Plot and platform mound (Zone E and Burial 4 in the side of the completed mound) excavations. One Belcher Engraved carinated bowl in Zone $\mathrm{H}$ in the platform mound indicates that all zones above $\mathrm{H}$ postdate ca. A.D. 1500 (the beginning of the Belcher phase in Northwest Louisiana, Kelley 2012).

Ceramic vessels of each of the three wares at the Hatchel site are predominantly tempered with grog (78.5 percent) (Table 4); grog-tempered plain wares are notable (86 percent). Another 15.4 percent of the vessels are tempered with both grog and burned bone, and the use of this temper combination is best represented in the utility wares.

Table 4. Temper identified in Texarkana phase ceramics at the Hatchel site.

\begin{tabular}{lcccc}
\hline Ware & Grog & Grog-bone & Shell & N \\
\hline Plain & 6 & 1 & - & 7 \\
Utility & 18 & 5 & 1 & 24 \\
Fine & 27 & 4 & 3 & 34 \\
\hline Totals & 51 & 10 & 4 & 65 \\
\hline
\end{tabular}

A total of 6.1 percent of the vessels at the Hatchel site are shell-tempered (see Table 3). Notably, approximately 8.8 percent of the fine ware vessels in the assemblage are shell-tempered. These particular shell-tempered vessels were likely not made in the Hatchel site community, but were obtained from both contemporaneous Belcher phase and McCurtain phase communities along the Red River (see Perttula et al. 2012). The shell-tempered vessels include an Avery Engraved jar in Zone D (Feature 12) in the platform mound, a lip-notched bowl in Zone G, a Keno Trailed, var. Glendora bottle in Burial 2 in Burial Plot 1, and a Belcher Engraved, var. Ogden bottle in Burial 2 in Village Plot 2.

More than 23 percent of the fine ware vessels in the Hatchel site ceramic vessel assemblage have either a red hematite-rich (Hatinu in Caddo) or white (Hah ki yo) kaolin clay pigment rubbed into the engraved designs (Table 5). The red pigments were clearly preferred by the Caddo potters at the Hatchel site, and one of the engraved vessels with a white pigment may be of non-local origin.

Table 5. Use of clay pigments in Texarkana phase vessels from the Hatchel site.

\begin{tabular}{lccc}
\hline Vessel type & Red pigment & White pigment & N \\
\hline Avery Engraved & 1 & 1 & 2 \\
Barkman Engraved & - & 1 & 1 \\
Hatchel Engraved & 2 & - & 2 \\
Simms Engraved & 2 & - & 2 \\
Unidentified Engraved CB & 1 & - & 1 \\
Unidentified Engraved Olla & 1 & - & 8 \\
\hline Totals & 6 & 2 & 1 \\
\hline
\end{tabular}

$\mathrm{CB}=$ carinated bowl 
According to Bobby Gonzalez of the Caddo Nation of Oklahoma (April 2008 personal communication), "the red pigment means life and is very sacred among the Caddo. The red pigment is now used on peyote staffs, and during ritual ceremonies and prayer meetings, the red pigment is painted on and in the ears as well as on the top of the head in the middle of a man's hair line, running from front to back; the women and men paint themselves in the morning when the sun comes up." Vessels found in domestic contexts in features in the platform mound with a red pigment likely are from vessels that symbolize life and its sacredness to the Caddo.

The Caddo "also use the red pigment when someone dies. If the deceased is a man we paint them in the middle hair line and on the face on each side of the eyes; if the deceased is a woman, another Caddo woman would paint her under the eyes." It is possible that the red pigment seen on vessels placed in Caddo burials at the Hatchel site may have been added to the vessels shortly before they were placed in the grave with the deceased.

"The white clay is also very sacred to the Caddo and was used for altars during Caddo peyote meetings. The white clay is used by the Caddo in doctoring people with cuts, burns, stomach problems, and other reasons" (Bobby Gonzalez, April 2008 personal communication). Even today, Caddo home places in Oklahoma have white and red clay altars, and some families still use these colors. 


\section{References Cited}

Brown, J. A.

1996 The Spiro Ceremonial Center: The Archaeology of Arkansas Valley Caddoan Culture in Eastern Oklahoma. 2 Vols. Memoirs No. 29. Museum of Anthropology, The University of Michigan, Ann Arbor.

Creel, D. G.

1996 Hatchel-Mitchell Site. In The New Handbook of Texas, Vol. 3, edited by R. Tyler, pp. 504-505. Texas State Historical Association, Austin.

Ferring, C. R. and T. K. Perttula

1987 Defining the Provenance of Red-Slipped Pottery from Texas and Oklahoma by Petrographic Methods. Journal of Archaeological Science 14:437-456.

Gilmore, K.

1986 French-Indian Interaction at an Early Eighteenth Century Post: The Roseborough Lake Site, Bowie County, Texas. Contributions in Archaeology 3. Institute of Applied Sciences, North Texas State University, Denton.

Hatcher, M. A.

1999 The Expedition of Don Domingo Teran de los Rios into Texas. In Wilderness Mission: Preliminary Studies of the Texas Catholic Historical Society, II, edited by J. F. de la Teja, pp. 1-66. Studies in Southwestern Catholic History No. 2. Texas Catholic Historical Society, Austin.

Jackson, A. T.

2003 Hatchel Site and Paul Mitchell Cemetery. Caddoan Archeology Journal 13 (No. 2):25-27.

2004 Excavation of an Earth Mound, Bowie County, Texas. Caddoan Archeology Journal 13 (No. 3/4):57-64.

Kelley, D. B.

2012 The Belcher Phase: Sixteenth- and Seventeenth-Century Caddo Occupation of the Red River Valley in Northwest Louisiana and Southwest Arkansas. In The Archaeology of the Caddo, edited by T. K. Perttula and C. P. Walker, pp. 411-430. University of Nebraska Press, Lincoln.

Krieger, A. D.

1946 Culture Complexes and Chronology in Northern Texas With Extension of Puebloan Datings to the Mississippi Valley. Publication No. 4640. The University of Texas, Austin.

Laughlin, J. T.

1940 Laboratory Study of the Pottery, Potsherds, and Artifacts from Site ET-30 Mound. MS on file, Texas Archeological Research Laboratory, The University of Texas at Austin.

Perttula, T. K.

2005 1938-1939 WPA Excavations at the Hatchel Site (41BW3) on the Red River in Bowie County, Texas. Southeastern Archaeology 24(2):180-198. 
2014a Archaeological Studies of the Hatchel Site (41BW3) on the Red River in Bowie County, Texas. Special Publication No. 23. Friends of Northeast Texas Archaeology, Austin and Pittsburg.

2014b The Eli Moores Site, a 17 th to Early $18^{\text {th }}$ Century Caddo Site on the Red River, Bowie County, Texas. Special Publication No. 31. Friends of Northeast Texas Archaeology, Austin and Pittsburg.

2014c The Mitchell Site (41BW4): An Ancestral Caddo Settlement and Cemetery on McKinney Bayou, Bowie County, Texas. Special Publication No. 32. Friends of Northeast Texas Archaeology, Austin and Pittsburg.

2015 East Texas Caddo Ceramic Sherd Database. Journal of Northeast Texas Archaeology 51:1-46.

Perttula, T. K. and B. Nelson

2003 Archeological Investigations of Village Areas at the Hatchel Site (41BW3), Bowie County, Texas. Report of Investigations No. 58. Archeological \& Environmental Consultants, LLC, Austin.

Perttula, T. K. and R. Z. Selden Jr.

2014 Ancestral Caddo Ceramics in East Texas. Journal of Northeast Texas Archaeology 48:9-58.

Perttula, T. K., J. E. Bruseth, N. A. Kenmotsu, and W. A. Martin

1995 Archeological Testing at the Cabe Mounds (41BW14), Bowie County, Texas. Cultural Resource Management Report 8. Department of Antiquities Protection, Texas Historical Commission, Austin.

Perttula, T. K., D. B. Kelley, and R. A. Ricklis (assemblers and editors)

2011 Archeological Investigations at the Lang Pasture Site (41AN38) in the Upper Neches River Basin of East Texas. Report No. 129. Texas Department of Transportation, Archeological Studies Program, Environmental Affairs Division, Austin.

Perttula, T. K., P. S. Marceaux, B. Nelson, and M. Walters

2015 Caddo Ceramic Vessels from Sites in the Upper Neches River Basin of East Texas, Anderson and Cherokee Counties, Texas. Special Publication No. 37. Friends of Northeast Texas Archaeology, Austin and Pittsburg.

Perttula, T. K., B. Nelson, and R. Z. Selden Jr.

2013 Documentation of Cemeteries and Funerary Offerings from Sites in the Upper Neches River Basin, Anderson, Cherokee, and Smith Counties, Texas. Special Publication No. 26. Friends of Northeast Texas Archaeology, Pittsburg and Austin.

Perttula, T. K., R. Z. Selden, Jr., and D. Wilson

2014 Corn is Life: Temporal Trends in the Use of Corn (Zea mays) by Caddo Peoples from Radiocarbondated Samples and Stable Isotope Analyses. Bulletin of the Texas Archeological Society 85:159-181.

Perttula, T. K., M. B. Trubitt, and J. S. Girard

2012 The Use of Shell-Tempered Pottery in the Caddo Area of the Southeastern United States. Southeastern Archaeology 30(2):242-267.

Perttula, T. K., C. P. Walker, and T. C. Schultz

2008 A Revolution in Caddo Archaeology: The Remote Sensing and Archaeological View from the Hill Farm Site (41BW169) in Bowie County, Texas. Southeastern Archaeology 27(1):93-107. 
Rice, P. M.

1987 Pottery Analysis: A Sourcebook. University of Chicago Press, Chicago.

Schambach, F. F. and J. E. Miller

1984 A Description and Analysis of the Ceramics. In Cedar Grove: An Interdisciplinary Investigation of a Late Caddo Farmstead in the Red River Valley, edited by N. L. Trubowitz, pp. 109-170. Research Series No. 23. Arkansas Archeological Survey, Fayetteville.

Skibo, J. M.

1992 Pottery Function: A Use-Alteration Perspective. Plenum Press, New York.

Story, D. A.

1990 Cultural History of the Native Americans. In The Archeology and Bioarcheology of the Gulf Coastal Plain, by D. A. Story, J. A Guy, B. A. Burnett, M. D. Freeman, J. C. Rose, D. G. Steele, B. W. Olive, and K. J. Reinhard, pp. 163-366. Research Series No. 38. 2 Vols. Arkansas Archeological Survey, Fayetteville.

Suhm, D. A. and E. B. Jelks (editor)

1962 Handbook of Texas Archeology: Type Descriptions. Special Publication No. 1, Texas Archeological Society, and Bulletin No. 4, Texas Memorial Museum, Austin.

Teltser, P. A.

1993 An Analytic Strategy for Studying Assemblage-Scale Ceramic Variation: A Case Study from Southeast Missouri. American Antiquity 58(3):530-543.

Webb, C. H.

1959 The Belcher Mound: A Stratified Caddoan Site in Caddo Parish, Louisiana. Memoirs No. 16. Society for American Archaeology, Salt Lake City.

Wedel, M. M.

1978 La Harpe's 1719 Post on Red River and Nearby Caddo Settlements. Bulletin 30. Texas Memorial Museum, Austin. 